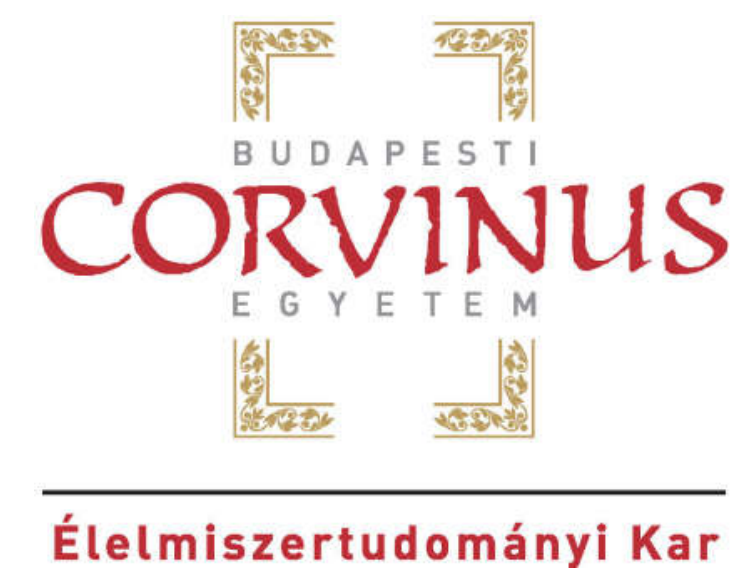

Doktori értekezés

\title{
ÍZ-KÖLCSÖNHATÁSOK ELEMZÉSE ELEKTRONIKUS NYELVVEL
}

Készítette:

Szöllősi Dániel

Témavezetők:

Dr. Fekete András† egyetemi tanár

Dr. Felföldi József egyetemi tanár

Dr. Kovács Zoltán egyetemi adjunktus

Budapesti Corvinus Egyetem

Élelmiszertudományi Kar

Fizika-Automatika Tanszék

Budapest, 2015 


\section{A doktori iskola}

megnevezése: Élelmiszertudományi Doktori Iskola

tudományága: Élelmiszertudományok

vezetője: Dr. Felföldi József,

egyetemi tanár, PhD

Budapesti Corvinus Egyetem

Témavezető: Dr. Fekete András†े, Egyetemi tanár, az MTA doktora

Fizika-Automatika Tanszék, Élelmiszertudományi Kar

Budapesti Corvinus Egyetem

témavezetés időtartama: 2010-2013

Dr. Felföldi József,

Egyetemi tanár, $\mathrm{PhD}$

Fizika-Automatika Tanszék, Élelmiszertudományi Kar Budapesti Corvinus Egyetem

témavezetés időtartama: 2013-

Dr. Kovács Zoltán,

Egyetemi adjunktus, $\mathrm{PhD}$

Fizika-Automatika Tanszék, Élelmiszertudományi Kar

Budapesti Corvinus Egyetem

témavezetés időtartama: 2013-

A doktori iskola- és a témavezető jóváhagyó aláíása:

A jelölt a Budapesti Corvinus Egyetem Doktori Szabályzatában elöírt valamennyi feltételnek eleget tett, a mühelyvita során elhangzott észrevételeket és javaslatokat az értekezés átdolgozásakor figyelembe vette, ezért az értekezés védési eljárásra bocsátható. 


\section{PhD Program}

Name: PhD School of Food Science

Field: Food Science

Head: Prof. József Felföldi

Corvinus University of Budapest

Supervisors: Prof. András Fekete†

Department of Physics and Control

Faculty of Food Science

Corvinus University of Budapest

period of supervision: 2010-2013

Prof. József Felföldi

Department of Physics and Control

Faculty of Food Science

Corvinus University of Budapest

period of supervision: 2013-

Zoltán Kovács, PhD

Department of Physics and Control

Faculty of Food Science

Corvinus University of Budapest

period of supervision: 2013-

The applicant met the requirement of the $\mathrm{PhD}$ regulations of the Corvinus University of Budapest and the thesis is accepted for the defence process.

Signature of Head of School

Signature of Supervisors 


\section{Tartalom}

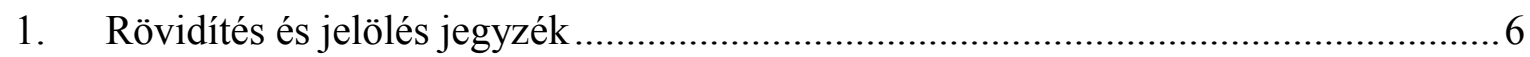

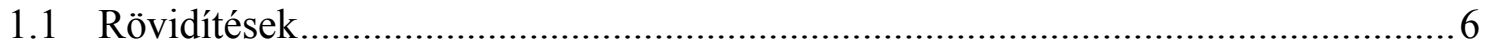

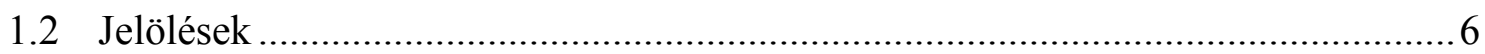

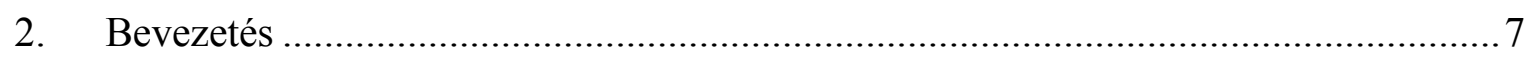

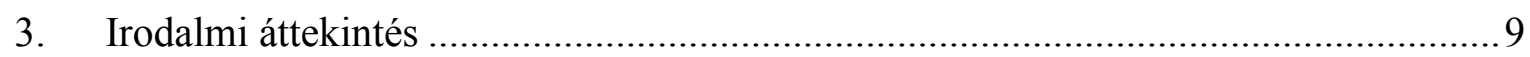

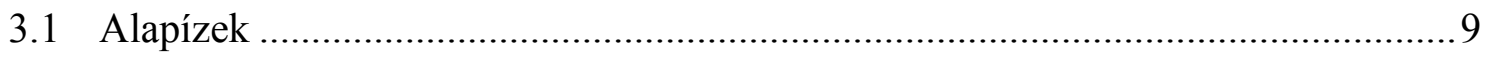

3.2 Az elektronikus nyelv története és müködési mechanizmusai .............................. 10

3.2.1 Az elektronikus nyelv kialakulása ........................................................... 10

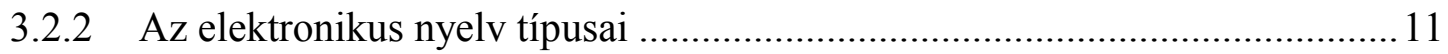

3.2.3 Az $\alpha$-Astree potenciometriás elektronikus nyelv müködési mechanizmusa .. 13

3.3 Alkalmazási területek ................................................................................. 17

3.4 Íz-kölcsönhatások az elektronikus nyelvvel kapcsolatban................................... 18

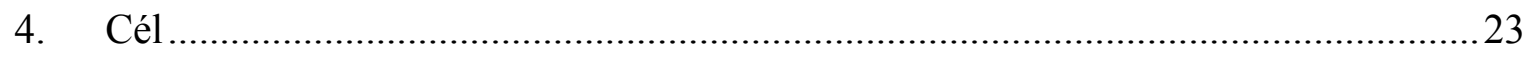

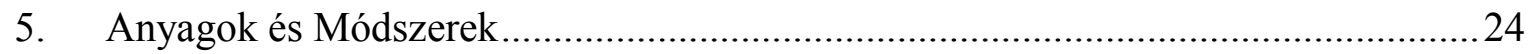

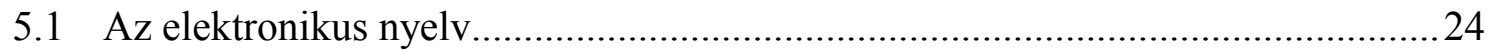

5.1.1 Az elektronikus nyelv felépítése és használata.........................................24

5.1.2 Az elektronikus nyelv szenzorjel stabilitása ...............................................26

5.1.3 Az elektronikus nyelv mérések beállításai.................................................26

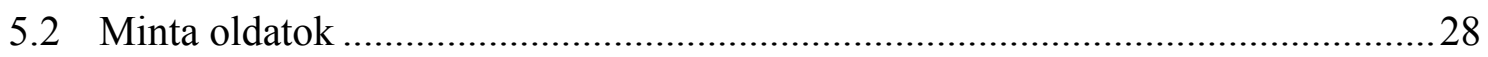

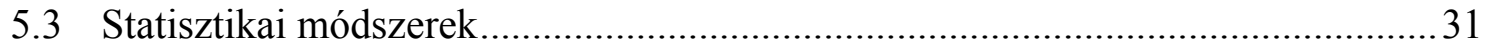

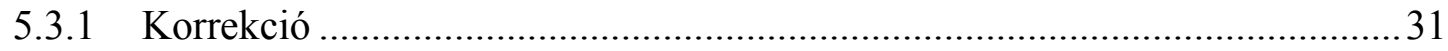

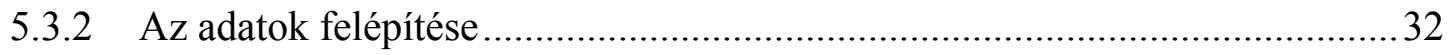

5.3.3 Minták közötti különbség: t-próba és euklideszi távolság.............................32

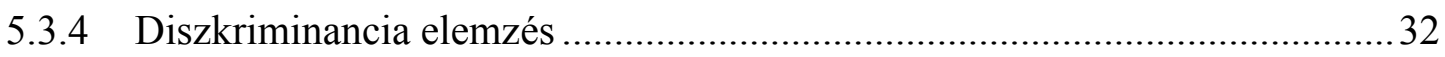

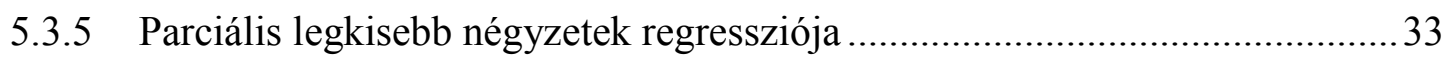

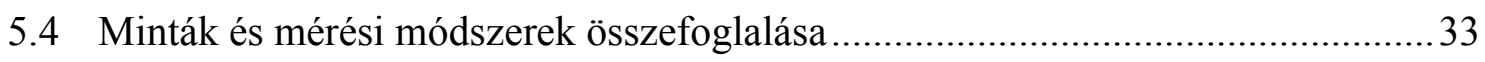

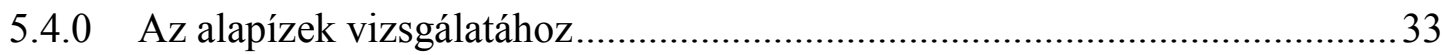

5.4.1 A citromsav és a $\mathrm{NaCl}$ interakciójának vizsgálatához .....................................33

5.4.2 A NaCl és a Na-glutamát interakciójának vizsgálatához.................................34

5.4.3 A koffein és a szacharóz interakcióinak vizsgálatához................................. 34

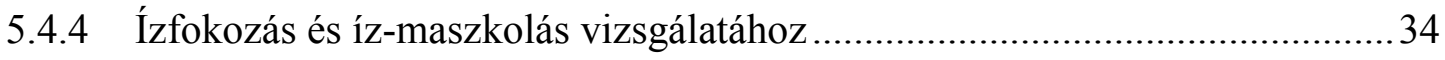

5.4.5 Interakciók koncentráció függésének vizsgálatához..................................... 34

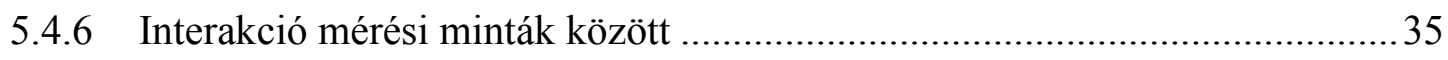

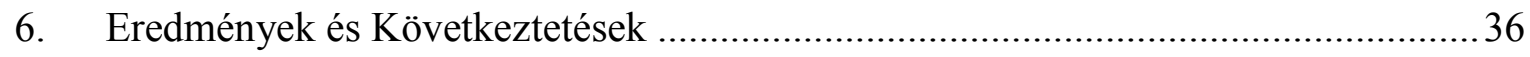




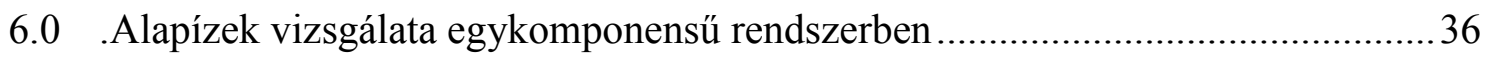

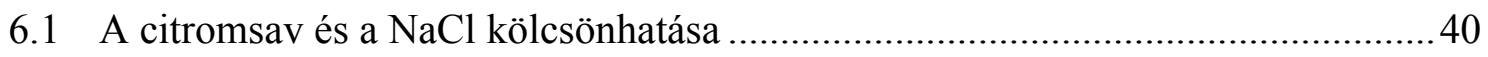

$6.2 \mathrm{~A} \mathrm{NaCl}$ és a Na-glutamát kölcsönhatása ................................................................ 48

6.3 A koffein és a szacharóz kölcsönhatása más anyagokkal ....................................54

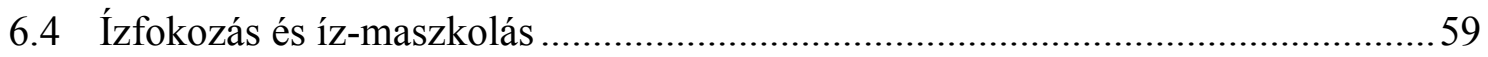

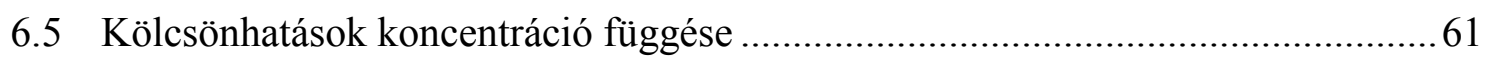

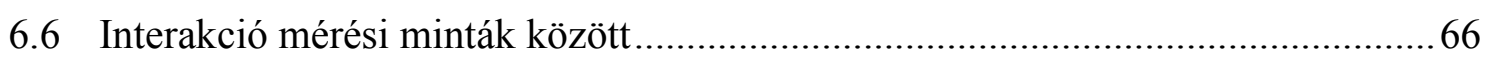

6.7 Módszer elektronikus nyelvvel mért oldatok összetevői közötti kölcsönhatások

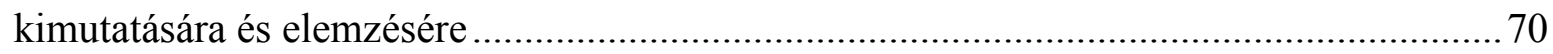

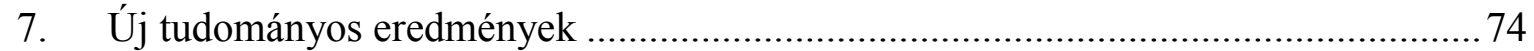

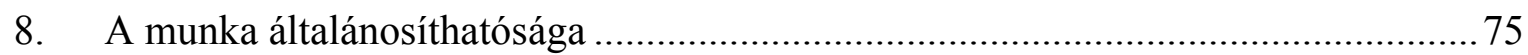

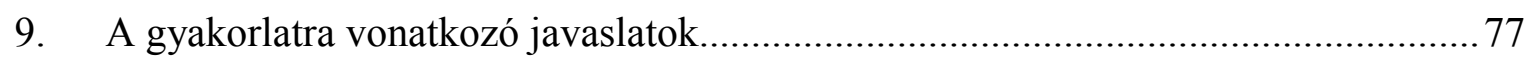

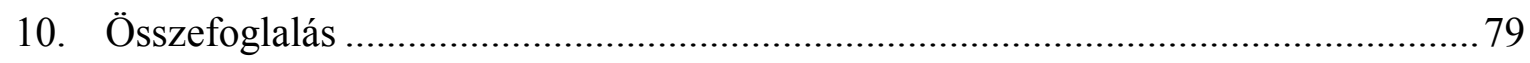

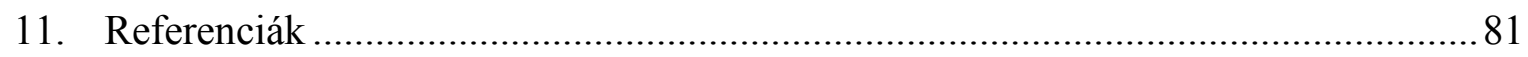

Melléklet - A dolgozat főrészéből kimaradt ábrák .......................................................... 88

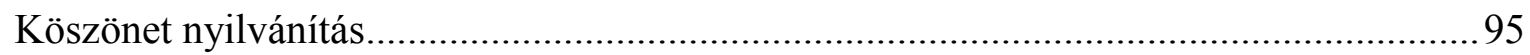




\title{
1. Rövidités és jelölés jegyzék
}

\author{
1.1 Röviditések \\ DV desztillált víz \\ DA Discriminant Analysis; diszkriminancia analízis \\ PLS Partial Least Squares (regression); parciális legkisebb négyzetek \\ (regressziója) \\ ISE Ion Selective Electrode; ion-szelektív elektród \\ MOSFET Metal-Oxid Semiconductor Field-Effect Tanzistor; fém-oxid \\ térvezérlésű tranzisztor \\ PVC poli(vinil-klorid)

\subsection{Jelölések} \\ centrum a mérések során alkalmazott kontroll minta, mely az öt alapíznek \\ megfelelő vegyületek keverékéböl állt össze és a mérések \\ összevethetőségére és korrekciójára használtam \\ citromsav $\mid \mathrm{NaCl}$ a minta, mely egyszerre tartalmazott citromsavat és NaCl-ot; a \\ kombináció voltát a '|' jelöli, az arányokat az Anyagok és Módszerek \\ fejezet (5.2.) részletezi
}




\section{Bevezetés}

Az élelmiszeriparban és kereskedelemben egyre nagyobb szerepe van a minőséget mérni és ellenőrizni képes módszereknek és eszközöknek. Ez jellemzően a fogyasztó és az ellenőrző szervek elvárása, de a gyártó számára is fontos tudni a félkész és kész termékek minőségi jellemzőit. A minősége egy élelmiszernek nagyon sokféle lehet, tulajdonképpen minden érzékszervünkhöz kapcsolhatunk pár jellemzőt és ennek megfelelően az ezt megmérni kívánó módszerek is számosak. A minőségi jellemzők között vannak olyanok is, melyeket gyártás közben vagy utána nem lehet megmérni, például azért mert a termék roncsolódik vagy egyszerüen müszeresen nehezen mérhető. Ilyen az élelmiszerek íze is. Bár analitikai módszerekkel nagyon sokféle komponenst pontosan meg lehet határozni, a meghatározáshoz ismernünk kell a mérendő összetevőt és célzott módszereket kell alkalmaznunk. Ráadásul az élelmiszerek nagyon komplex keverékek, melyeknél néhány összetevő pontos ismerete is csak távolról jellemzi a minta ízét. Erre a problémára nyújt egy lehetséges megoldást az elektronikus nyelv.

Az elektronikus nyelv koncepció eleve nem kívánja a mintát összetétel szinten leírni, hanem más mintákkal való összefüggésben a hasonlóságokról, de még inkább a különbségekről ad felvilágosítást. A müszer segítségével, ha csak egy mintát mérünk meg, jobbára nem tudunk semmit sem mondani. Azonban ha lemérünk néhány ismertnek tekinthető referencia mintát vagy egyéb információnk van a minták egymáshoz való viszonyáról (pl.: valamilyen sorozatot alkotnak), akkor a kapott eredmények értelmezhetővé válnak. A mérés elve lehetővé teszi akár absztrakt tulajdonságok mérését is, mint amilyen a fogyasztói kedveltség, hisz ismert kedveltségű mintákkal kalibrált modellből egy ismeretlen (de nem túlságosan különböző típusú) minta kedveltsége becsülhető.

Az elektronikus nyelvvel kapcsolatban (főleg az alkalmazások terén) jelenleg is igen aktív kutatás folyik, a Web of Science 2015 decemberében az 'electronic tongue' kereső kifejezésre 5192 tudományos mủvet talált (1226-ot, ha csak a címben keresünk) és a publikációk száma évről évre egyre nő. A terület fontosságát jellemzi, hogy igen szerteágazó és számos alkalmazási lehetőségeit írták már le, ezek főleg az élelmiszer- és gyógyszeripar, valamint a környezetvédelem területéhez kapcsolódnak.

Az elektronikus nyelvről rendelkezésünkre álló ismereteknek egy fontos és egyben érdekes szelete a mért mintákban található összetevők közötti, szenzorjeleket meghatározó kölcsönhatások jellege. Mivel az elektronikus nyelvvel mért minták szinte mindig egynél több oldott komponenst tartalmaznak (ezért is mérik elektronikus nyelvvel és nem valamelyik 
klasszikus analitikai módszerrel) magától értetődő a kölcsönhatások gyakori és meghatározó jelenléte vagy legalább is lehetősége. Az eddig publikált kölcsönhatásokkal foglalkozó müvekben jobbára csak a keserü íz különböző módú elfedését/maszkolását vizsgálták, mely leginkább a gyógyszeriparnak fontos.

Munkámban az Alpha Astree elektronikus nyelv mérési eredményeit befolyásoló íz kölcsönhatásokat igyekeztem felderíteni a hatások globális és szenzor szintű elemzésével. Az elektronikus nyelvet érintő mintaösszetevő kölcsönhatások vizsgálata jelentősen hozzájárul az elektronikus nyelvről szerzett elméleti tudásunkhoz. Ezen túlmenően hasznos gyakorlati javaslatokkal szolgál mind méréstechnikai, mind kiértékelési szempontból. A kölcsönhatások vizsgálatához az öt szabványosnak tekinthető, alapízeknek megfelelő vegyületekből készített tiszta és kombinált oldatokat és élelmiszer mintákat vizsgáltam egy, az ismert zavaró hatásokat minimalizáló mérési módszerrel.

A minta összetevők közötti kölcsönhatások elektronikus nyelvre gyakorolt hatásának vizsgálata egy viszonylag új kutatási irányvonalat képvisel a tanszéken folyó eddigi kutatásokhoz képest. A dolgozat egyfajta előzményének tekinthető egy 2013-as konferencián bemutatott munka, mely a glükóz hatását elemezte önmagában valamint citromsav, $\mathrm{NaCl}$ vagy koffein jelenlétében [Szöllősi és mtsai. 2013]. Már itt sejteni lehetet, hogy a glükóz hatása függ az egyéb oldatban jelenlévő összetevőktől is. A citromsav és a glükóz hatását almalevekre egy 2011-es cikkünkben elemeztük [Kovács és mtsai. 2011], igaz itt még az additívnál bonyolultabb kölcsönhatások nem merültek fel. Egy későbbi cikkünkben különböző klasszifikációs algoritmusokat összehasonlítottunk össze [Szöllősi és mtsai. 2012]. Ehhez az adatokat különböző szacharózzal kiegészített kóla ízű üdítők szolgáltatták. Ezen minták a nehéz megkülönböztethetőségük miatt kerültek fókuszba. 


\section{Irodalmi áttekintés}

\subsection{Alapízek}

Az alapízek ötletét elsőnek Hans Henning írta le 1916-ban. Négy alapízt különböztetett meg (édes, keserü, sós, savanyú) és egy térbeli tetraéder sarkaiként egyfajta íz-térként képzelte el egymáshoz képesti viszonyukat. Később, ehhez a négy alapízhez csatlakozott ötödiknek az umami íz is [Delwiche 1996]. Azt, hogy egy íz alapíz-e, többféle kritérium alapján is megpróbálták meghatározni. Egyrészt fiziológiai alapon, nevezetesen, hogy specializált receptora van a szájban (nem feltétlenül a nyelven), azonban erről később kiderült, hogy több ilyen is van mint négy vagy öt [Kinnamon és mtsai. 1992]. Mások inkább kulturális/nyelvészeti kritériumokat vettek figyelembe, azaz az alapízeknek a nevei alapvetőnek, etimológiailag más mélyebb gyökerekre nem visszavezethetőnek kell lennie. Ennek a kulturális kritériumnak az édes, keserü, sós és savanyú meg is felel (legalább is az angol nyelvben mindenképpen) [Lawless és mtsai. 2010]. Mindezek mellett az alapíz elmélet a mai napig vitatott és sok kritika éri [Erickson 2008].

Munkámban azért maradtam az alapízek mellett, mert a jelenleg hatályos érzékszervi elemzés szabványában a bírálók kiválasztására és felmérésére alapíz oldatokat használnak [ISO/FIDS_3972:2011 2011], tehát létezik szabványos édes (szacharóz), keserü (koffein), sós $(\mathrm{NaCl})$, savanyú (citromsav) és umami (Na-glutamát) íz. A dolgozatban későbbiekben ezekkel a szabványos anyagokkal leírható/előállítható ízeket nevezem alapízeknek és a savas íz esetében mindig citromsav savasságra gondolok, keserü íz esetében koffein keserüségre és így tovább. Választásomat indokolja, hogy számos elektronikus nyelvvel foglakozó tudományos müben modell oldatokként alapíz oldatokat használnak [Cole és mtsai. 2015, Kobayashi és mtsai. 2010, Tahara Y. és mtsai. 2013, Xiao és mtsai. 2012], melyeket sokszor a szabványban említett vegyületek felhasználásával állítanak elő. Ezen felül a kiválasztott vegyületek kémiai tulajdonságaikban (polaritás, oldhatóság, oldatbéli töltés) egy meglehetősen széles spektrumot ölelnek fel. Ha vannak az egyes ízzel rendelkező vegyületek között kölcsönhatások az elektronikus nyelv szempontjából, akkor ezen vegyületek között szinte biztosan tetten érhetjük azokat.

Az ízek vagy oldott komponensek kölcsönhatásán általánosságban egy a statisztikai kölcsönhatáshoz hasonló fogalmat kell érteni. Két oldott komponens kölcsönhatásban van egymással, ha a keverék minta szenzorjele nem állítható elő a tiszta minták szenzorjeleinek egyszerü összegzéséböl vagy átlagként. Ennek egyik következménye, hogy a tiszta minták 
szenzorjeleinek ismeretében nem tudjuk pontosan megbecsülni a keverék elektronikus nyelvvel kapható eredményét, csak ha már rendelkezünk a komponensek közötti kölcsönhatásokról információval. A kölcsönhatások lehetnek egymást erősítő (ízfokozás) vagy gyengítő (maszkolás) jellegüek, de elképzelhető, hogy egy keverék a szenzorjeleket a várttól teljesen eltérő módon módosítja, mintha nem egy keverékről, hanem egy teljesen új összetevőröl lenne szó.

\subsection{Az elektronikus nyelv története és müködési mechanizmusai}

\subsubsection{Az elektronikus nyelv kialakulása}

Az elektronikus nyelv az ion-szelektív elektródokkal kezdődött, melyek közül a legismertebb és máig leggyakrabban használt a $\mathrm{H}^{+}$ion szelektív $\mathrm{pH}$ szenzor. Nagyon sokáig az elektrokémiai szenzorok fejlesztésének fö iránya a szelektivitás és szenzitivitás növelése volt. Evvel szemben merült fel 1982-ben egy az emberi érzékelést utánzó koncepció, mely a szelektív szenzorok helyett párhuzamosan alkalmazott és csak részlegesen szelektív érzékelőket használ. Az első ilyen elven müködő rendszerek gáz szenzorokból épültek fel és mint ilyenek gáz fázisú keverékek (illatok) elemzésére voltak alkalmasak [Persaud és mtsai. 1982]. A folyadékokban használható, mérési elvében teljesen különböző, de koncepciójában azonos érzékelő sorok a 90-es évek elején jelentek meg [Hayashi és mtsai. 1990] és csak 1996-tól nevezték ezeket elektronikus nyelvnek (electronic tongue) vagy íz-elemzőnek (taste analyzer) [Toko 1996]. Az elképzelés egyik motivációja, hogy nem lehetséges (ésszerü költségek mellett) a mérendő minta minden egyes komponensét megmérni [Tahara Y. és mtsai. 2013]. Másik előnye a multiszenzor rendszernek, hogy érzékenyen képes különbséget tenni olyan oldatok között is ahol szelektív elektródok nem használhatóak.

A több szenzorból álló mérőrendszer a lemért mintára nem egy számot eredményez, hanem egy jelmintázatot (fingerprint), mely az alkalmazott érzékelők számának megfelelő mérési érték sorozatot tartalmaz és mely jelmintázat jellemző az adott mintára. Az adatok mennyiségét tovább növelheti, ha egy adott mintára és szenzorra nem is csak egy adat pontot, hanem egy teljes 'spektrumot' veszünk fel, ahogy az az impedimetriás méréseknél történik (lsd. 3.2.2 fejezet). A kapott jelmintázat jellemző a lemért mintára, mint egyfajta ujjlenyomat [Tahara Yusuke és mtsai. 2013]. A jelmintázatok elemzése és összehasonlítása többváltozós statisztikai módszerekkel lehetséges és célszerü, melyre nagy mennyiségü példát mutatnak be Escuder-Gilabert és Peris összefoglaló munkájukban [2010].

Az elektronikus nyelvvel kapcsolatban Toko és kutató csoportja [Kobayashi és mtsai. 2010] két alapvető kritérium sorozatot fogalmaz meg a müszerek céljait illetően. Szerintük azt nevezzük elektronikus nyelvnek (Electronic Tongue), mely igen érzékenyen képes 
különbségeket tenni oldatok között, de képességei leginkább ebben a különbség tételben merülnek ki. Ezzel szemben az íz-érzékelö (Taste Sensor) mérési képességeiben a lehető legjobban kell, hogy hasonlítson az emberi íz érzékeléshez. Hasonló érzékenységgel (ízküszöb értékkel), konzisztens mérési eredményekkel rendelkezzen és ugyan azok az íz kölcsönhatások jellemezzék, mint az emberi érzékelést.

Vlasov és Legin [2005] akik vezető kutatói a területnek az elektronikus nyelvet a következőképpen definiálják: „az elektronikus nyelv egy olyan analitikai müszer, mely tartalmaz egy részleges specificitású és nem szelektív kémiai szenzor sorozatot, melynek jelei a megfelelő mintázat felismerő algoritmus felhasználása után alkalmasak egyszerü és komplex oldatok kvalitatív és kvantitatív elemzésére". A részleges specificitáson és a szelektivitás hiányán azt kell érteni, hogy az oldatok összetevői egyszerre több érzékelőre is hatnak eltérő mértékben.

\subsubsection{Az elektronikus nyelv típusai}

A fenti definíció igen sokféle berendezéssel megvalósítható, tekintve, hogy az egyetlen elvárás, hogy több kereszt-érzékeny érzékelő legyen a müszerben. Az alábbi felsorolás bemutat néhány föbb megvalósítási elvet.

Potenciometriás elv: Ez a típus feszültség mérésen alapszik. A szenzorok között nem folyik áram így a mérés által kiváltott elektrokémiai reakciók sem játszódnak le. Viszonyítási pontként leggyakrabban $\mathrm{Ag} / \mathrm{AgCl}$ referencia elektródot használnak. A szenzorok érzékenységét felületi bevonatuk határozza meg, mely leggyakrabban polimer membránba ágyazott különféle lipid összetevőket jelent [Winquist és mtsai. 2004]. Az érzékelő-membrán felületén a membrán összetételének megfelelő szelektivitással létrejön a kapcsolat a mért oldattal és az eltérő összetételü oldatok különböző potenciált alakítanak ki a felületen, melyet a müszer detektál. Ebbe a csoportba tartoznak az ion-szelektív elektródokra (ISE) alapuló elektronikus nyelvek is [Bratov és mtsai. 2010]. Erről a típusról részletesen szólunk még a következő fejezetben (3.2.3), mivel az általam használt műszer is ebbe a kategóriába tartozik.

Voltammetriás elv: Ebben a típusban a mérés során nemesfém elektródok és egy kellően nagy vezetőképességű referencia elektród közé ismert időbeni lefutású és nagyságú feszültséget kapcsolnak, miközben az átfolyó áramokat mérik. A feszültség időbeni lefutása lehet impulzus (pulse voltammetry), ciklikus (cyclic voltammetry) és visszaoldásos (stripping voltammetry) típusú [Winquist 2008, Winquist és mtsai. 2004]. Az elektródokra kapcsolt feszültség hatására a felületen redox reakció játszódik le, melynek eredményeként áram folyik át az elektródokon. Emiatt csak kellően nagy vezetőképességű oldatokban használható sikerrel a technika. A kapcsolt feszültségek hatására átfolyó áram a mintaoldat összetételétől függ, hisz minden egyes redox reakciókra képes összetevő a rájellemző feszültségen lép 
reakcióba és járul hozzá a mérhető áramhoz. A rendszer érzékenysége igen nagy, szelektívvé tehető és felépítése robosztus. A mért jel karakteréből egyszerre lehet következtetni az oldatban található töltött és elektromosan aktív komponensekre, valamint azok diffúziós állandójára.

Konduktometriás elv: A konduktometriás (vagy impedimetriás) rendszerekben a szenzorok oldatokban mérhető váltakozó áramú ellenállását mérik. Az alkalmazott váltakozó áram frekvenciája lehet fix vagy változhat széles határok között $\left(10-10^{6} \mathrm{~Hz}\right)$, így minden szenzor, minden mintára egy teljes impedancia spektrumot szolgáltathat. Az érzékelők érzékenységét meghatározó felületet valamilyen vezetőképes polimerből alakítják ki [Escuder-Gilabert és mtsai. 2010, Winquist és mtsai. 2004]. A polimer oldatbéli felülete biztosítja a szelektivitást és a kialakuló elektromos kettősréteg jelentős kapacitással rendelkezik, ami meghatározza a mérhető impedanciát [Grimnes és mtsai. 2008]. Ez a rendszer is igen érzékeny, képes alapíz oldatokat (kinin, szacharóz, $\mathrm{HCl}$ és $\mathrm{NaCl}$ ) felismerni ppb koncentrációban [Winquist és mtsai. 2004]. A műszer további előnye, hogy nem szükséges, hogy a mérendő komponens elektromosan aktív legyen, illetve különleges referencia elektródra sincs szükség.

Piezzo-elektromos elv: Egy tisztán fizikai elven müködő elektronikus nyelv a Cole és munkatársai által készített, a felületi akusztikus rezgések (Surface Acoustic Wave) elvén működő szenzor [Cole és mtsai. 2015]. Az érzékelő egy folyadékba merített piezzo rezonátor melyet $\sim 434,7 \mathrm{MHz}$-es frekvencián, elektromosan hoznak rezgésbe. A szenzor rezonancia frekvenciája a szenzor felületével érintkező folyadék tulajdonságaitól függ. Az érzékelő elektro-akusztikus mérési elve miatt, egyszerre érzékeny a vizsgált folyadék vezetőképességére, dielektromos permittivitására, sűrűségére és viszkozitására (és természetesen a hőmérsékletére). A szenzor felületén nincs érzékenyítő bevonat. A müszer segítségével mind az alapíz oldatokat $(0,1 \mathrm{M})$, mind bináris keverékeiket meg tudták különböztetni, valamint koncentráció sorozatokat jó eredményekkel mértek. További előnyének tartják a műszer gazdaságos előállíthatóságát.

Biológiai elv: $\mathrm{Wu}$ és mtsai. összefoglalójukban egy íz-receptor sejtek segítségével készített elektronikus nyelvet tárgyalnak [2014]. Az ilyen módon készített elektronikus nyelv a sejtekben található szelektív receptorok révén eleve a megfelelő érzékelési spektrummal rendelkezik. A legnagyobb nehézséget a sejtek megfelelő előkészítése és valamilyen mérőátalakítóhoz kapcsolása jelenti. A sejteket állatokból vagy sejt vonalakból (melyek esetenként genetikailag módosítottak) nyerik és többnyire valamilyen potenciometriás elven működő rendszerhez csatolják, mely képes a sejt által keltett ingerületet érzékelni. 
Molekuláris 'imprinting': Xiao és mtsai. $\mathrm{TiO}_{2}$ membránba ágyaztak citromsav, D-glükóz, kinin, $\mathrm{HCl}$ és Na-glutamát molekulákat, melyeket később a megszilárdult membránból kimostak. Az így kapott molekuláris lenyomatokkal sikeresen tudták érzékelni és megkülönböztetni a fent sorolt vegyületekből készített oldatokat. A jelet potenciometriás elven észlelték [Xiao és mtsai. 2012].

\subsubsection{Az $\quad \alpha$-Astree potenciometriás elektronikus nyelv müködési mechanizmusa}

Munkámban az Alpha M.O.S. Alpha Astree 2 elektronikus nyelvvel dolgoztam, mely egy potenciometriás elven müködő elektronikus nyelv. A müszerben használt érzékelő szenzorok egy $\mathrm{Ag} / \mathrm{AgCl}$ referencia elektródhoz képest mérik a szenzor felületén kialakuló potenciált. A hét munkaelektród mindegyike tartalmaz egy speciális PVC alapú membránt, melybe szenzoronként eltérő lipid összetevőket ágyaztak és melynek pontos összetétele általunk nem ismert. Az egyes szenzorok felépítése a következő: A szenzor alapját egy kapu kivezetés nélküli MOSFET (Metal-Oxid Semiconductor Field-Effect Tranzistor; fém-oxid térvezérlésü tranzisztor) chip alkotja, mely az 1. ábra közepén, mint sötétebb négyzet jól megfigyelhető. A MOSFET kapu régiójára (az ábrán középen, egészen sötét négyzet), egy speciális lipidekkel kiegészített PVC membrán található (a kissé opálos bevonat a felületen), mely a szenzor szelektivitásáért felel [AlphaM.O.S. 2002b].

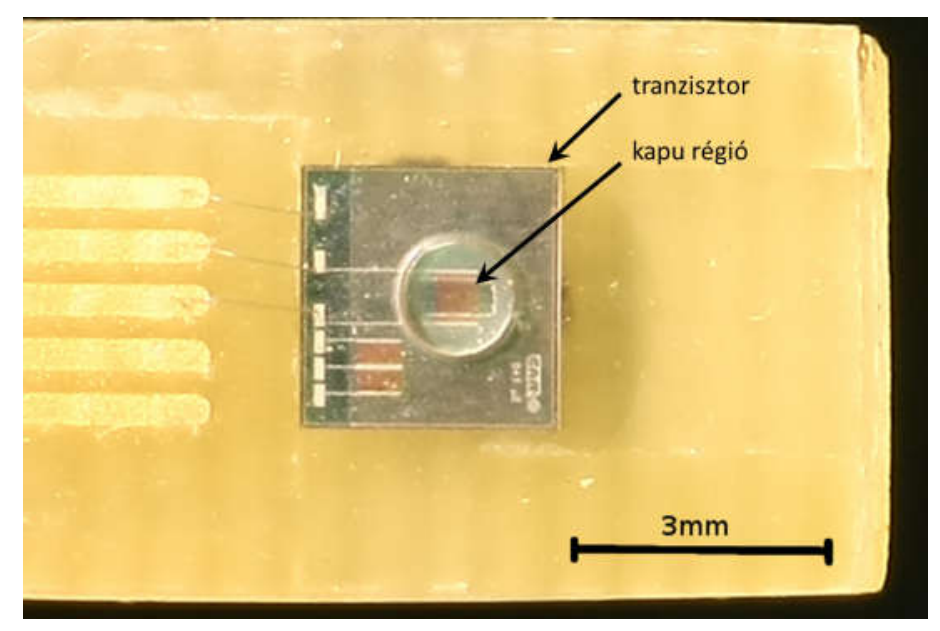

1. ábra Az $\alpha$-Astree elektronikus nyelv egy szenzora.

A szenzorok felépítését (mely a PVC membrán kivételével teljes mértékben megegyezik egyes ion-szelektív elektródokéval) és egyben elektronikai működési mechanizmusát mutatja összevetve egy MOSFET-tel a 2. ábra, melyet Bergveld összefoglaló munkájából vettem át [Bergveld 2003]. A MOSFET tranzisztor átfolyó áramát a Gate (kapu) kivezetésen található feszültség határozza meg. Mivel a Gate egy $\mathrm{SiO}_{2}$ szigetelő réteggel van elválasztva a tranzisztor többi részétől ezért áram rajta nem folyik keresztül és így az éppen vizsgált 
oldaton keresztül sem folyik át áram, tehát az áram hatására végbemenő elektrokémiai reakciókkal nem kell számolni. Mivel az elektronikus nyelv szenzorokban a Gate kivezetés helyén a szelektív membrán és azon túl pedig a mérendő folyadék található, a mérö-átalakító tranzisztoron (a Source (forrás) és Drain (nyelő) között) átfolyó áramot a membrán felületén kialakuló potenciál határozza meg. Így árammérés segítségével (melyet igen pontosan lehet kivitelezni) határozhatjuk meg a szenzor felületén kialakult potenciált. Mivel a felületi potenciált a membrán közvetlen közelében jelenlévő folyadék összetevők határozzák meg, a mérés a folyadék összetételéről nyújt információt. A különböző összetételü membránok eltérő típusú anyagok kapcsolódását teszik lehetővé. Több szenzor együttes alkalmazásával egy feszültség mintázatot kapunk minden egyes lemért oldatra és a mintázat az adott oldatra ujjlenyomat (fingerprint) szerűen egyedi lesz.

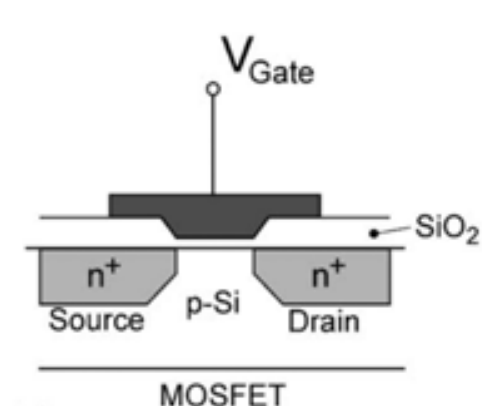

(a)

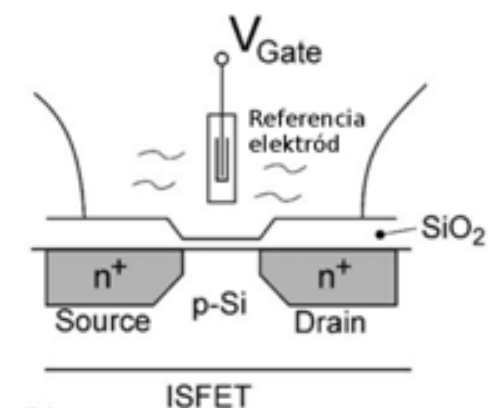

(b)

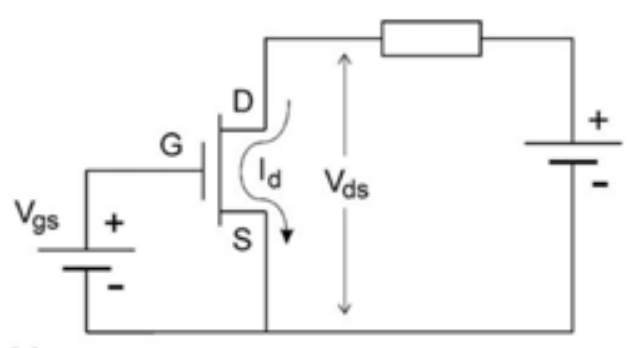

(c)

2. ábra MOSFET és ISFET összehasonlítása [Bergveld 1970]. p-Si: P típusú félvezető szilikon; D: Drain; S: Source, G: Gate; VGs: Gate feszültség; VDs: Drain feszültég; IDS: Drain áram

Egy másik szintén potenciometrikus elektronikus nyelvben a következő lipideket alkalmazták érzékenyítő anyagként: n-decil-alkohol, olajsav, dioktil-fosztát-bisz-2-etilhexilhidrogén-foszfát (DOP), trioktil-metil-ammónium-klorid (TOMA) és oleil-amin esetenként akár keverékben is [Delwiche 1996]. Az általunk használt elektronikus nyelv szintén lipid összetevőket használ a szenzorok érzékenyítésére, azonban az összetételt szabadalom védi és azt nem ismerjük [AlphaM.O.S. 2002b]. Ezen ismeret hiánya abból a szempontból nem okoz gondot, hogy jelenlegi ismereteink szerint még a pontos összetétel tudatában sem tudjuk elöre megmondani, hogy az érzékelö felületén milyen potenciálnak kell egy adott oldat esetében 
kialakulni [Vlasov és mtsai. 1997]. Az irodalomban a következő ismeretek lelhetőek fel a témával kapcsolatban.

Grimnes [2008] Bioimpedance \& Bioelectricity c. könyvében a folyadékba merülő szilárd felületen lejátszódó folyamatokat az általánosított Stern elmélettel írja le (General Theory of Stern). Az elmélet szerint a felületen kialakul egy viszonylag stabil ion réteg, mely a disszociált szilárd felület polaritásának megfelelően alakul ki és ezt hívja Stern rétegnek (3. ábra). A Stern rétegbe tartoznak a felületen adszorpcióval kötődő összetevők is, az adszorpciós jelenségeket a Langmuir adszorpciós izoterma írja le. A Stern réteg vastagsága nagyjából megegyezik a felületen kötődő hidratált ionok sugarával $(\delta)$. A Stern réteg után a Gouy réteg található, mely többé-kevésbé szabadon mozgó, a Stern rétegben található ionokkal ellentétes töltésü ionokból áll. A Stern réteg határán kialakuló feszültséget $\zeta$ potenciálnak nevezik, mely megegyezik a kísérletesen meghatározható (és az elektronikus nyelv szempontjából mérhető) elektrokinetikus potenciállal. A könyvben közölt egyenletek megoldása még igen egyszerü oldatokra ( $\mathrm{pl}$.: híg $\mathrm{NaCl}$ oldat) is meglehetősen bonyolult, melyet a szerző is elismer.

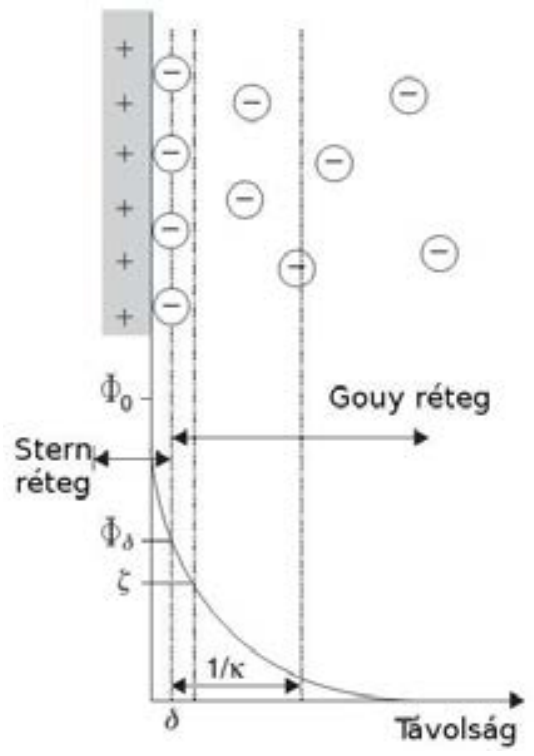

3. ábra A Stern elmélet régiói [Grimnes és mtsai. 2008].

Empirikusan közelítve a témához Oohira és mtsai. szerint a mérhető potenciál a felületi potenciál és a diffúziós potenciál összegeként jön létre. Fontos itt megjegyezni, hogy a csoport által kifejlesztett elektronikus nyelvben a membrán mögött nem egy félvezető, hanem egy telített $\mathrm{KCl}$ oldat foglalt helyet, így volt tere a diffúziónak. Kifejtik továbbá, hogy a felületi potenciált az oldott ionok mennyisége, valamint az összetevők hidrofobicitási viszonyai határozzák meg, mely utóbbit a membránban található lipidek nagyban befolyásolják [Kinnamon és mtsai. 1992]. 
Tahara és munkatársai az elöbbi elméletet fejlesztették tovább és külön jelentőséget tulajdonítanak a felületi adszorpció által létrehozott potenciál változásnak (olyannyira, hogy mérési metodikájukban külön mérték ezt egy tisztító oldat segítségével). Szerintük az egyes érzékelőket specializálni lehet az egyes alapízekre, ha a hidrofobicitási viszonyokat megfelelően beállítják a membrán összetétellel. Példának a többnyire hidrofób keserü vegyületeket hozzák fel, melyeket szerintük egy kevés töltéssel rendelkező lipidet tartalmazó szenzorral érdemes mérni [Tahara Y. és mtsai. 2013].

Kobayashi és mtsai. szerint az elektronikus nyelvben használt szenzorok szelektivitását a membrán hidrofóbicitása és folyadékban kialakuló töltés sürüsége határozza meg [Kobayashi és mtsai. 2010]. Munkájukban a Grimnes által részletesen tárgyalt [2008] Gouy-Chapman és Poisson-Boltzmann egyenletekre hivatkoznak. A számított és kísérletekben meghatározott eredmények alapján az alábbi következtetésekre jutottak (4. ábra):

1. A vízbe merülő szenzor felületén a membránba ágyazott lipidek disszociálnak evvel egy negatívan töltött felületet hozva létre (A).

2. Savas jellegű anyagok gátolják a disszociációt és ezáltal módosítják a felületi potenciált (B). Eredményeik itt jó egyezést mutattak a számított értékekkel.

3. A NaCl egyfajta árnyékoló hatást (screening effect) fejt ki a membrán felületének közelében és így módosítja a felületi potenciált $(\mathbf{C})$. Eredményeik itt is jó egyezést mutattak a számított értékekkel.

4. Kinin esetében a kísérletesen meghatározott potenciál változás kisebb volt, mint az elméletileg meghatározott érték, ami állításuk szerint a modellben meghatározottól eltérő hatás mechanizmus miatt történt. Ebben az esetben azt is kimutatták, hogy a kinin adszorbeálódott a membránba és így módosította annak töltés sűrüségét (D).

5. Na-glutamát esetében más eredményeket kaptak elméleti és kísérleti úton. A mért membrán potenciál a várttal ellentétben negatívabb volt, mint desztillált víz esetében. 
(A) Normál állapot

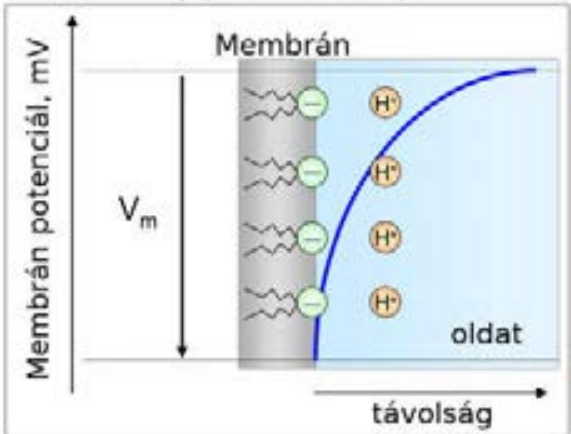

(C) $\mathrm{NaCl}$ oldatban

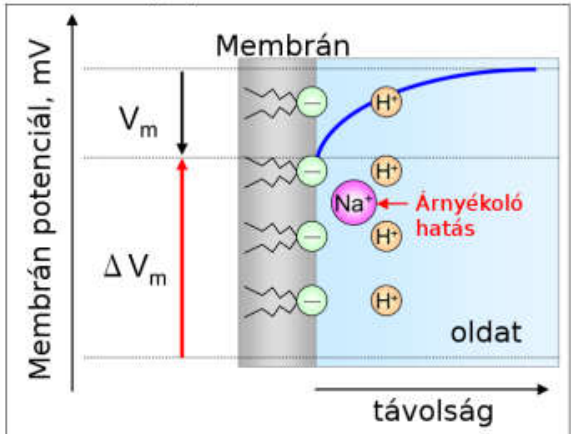

$\Theta$ : negatívan töltött lipid
(B) $\mathrm{HCl}$ oldatban

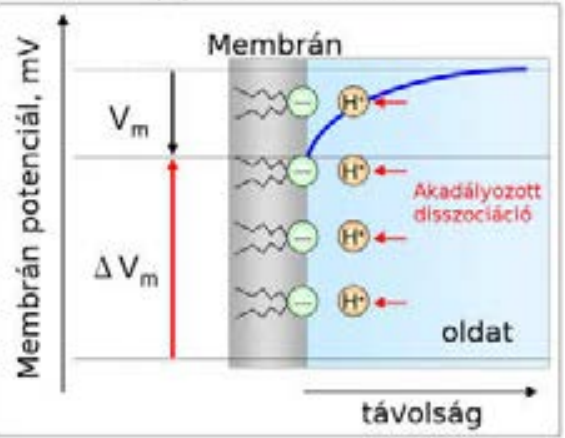

(D) Kinin oldatban

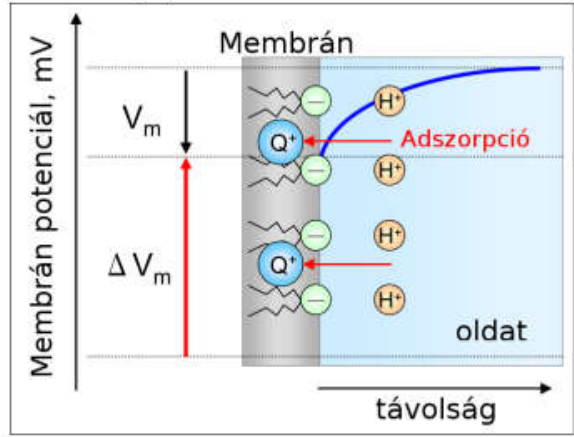

4. ábra Az elektronikus nyelv érzékelőinek membránján lejátszódó folyamatok különböző komponensek hatására Kobayashi és mtsai. nyomán [Kobayashi és mtsai. 2010].

Az ion-szelektív elektródok esetében [Bergveld 1970] és a müködési mechanizmusukban hasonló potenciometriás elektronikus nyelvek esetében is a mérhető jel és egy adott vegyület oldatának koncentrációja között logaritmikus jellegü összefüggést írtak le [Kinnamon és mtsai. 1992, Vlasov és mtsai. 2002, Yasuura M. és mtsai. 2014]. Azonban részlegesen szelektív elektródokra a koncentráció - szenzorjel fizikai összefüggést sajnos még nem adta meg senki. A logaritmikus kapcsolat megfelel saját korábbi tapasztalataimnak is.

\subsection{Alkalmazási területek}

Az elektronikus nyelv lehetséges alkalmazásaival nagyszámú publikáció foglalkozik, csak a címben keresve az 'electronic tongue' és 'application' kifejezésekre 445 találatot adott a Web of Science 2015 decemberében. Emellett több igen nagyszerü összefoglaló munka is megjelent a témában, melyek részletes táblázatokban foglalják össze az alkalmazott elektronikus nyelvek típusát, az alkalmazás célját, a mintákat és a kiértékelés módját.

Az élelmiszer ipari alkalmazásokat Escuder-Gilabert és munkatársa [2010] foglalta remekül össze. A területet hat részre osztotta: folyamat követés, frissesség vizsgálat és 
eltarthatóság, eredetiség vizsgálat, élelmiszer jellemzés, kvantitatív elemzések és végül egyéb vizsgálatok.

Az elektronikus nyelv egy másik ígéretes alkalmazási területe a gyógyszeripar, mivel a müszerrel különösebb egészségügyi kockázat nélkül tesztelhető kísérleti gyógyszerek íze. A terület releváns összefoglalását Woertz és munkatársai készítették el [2011b]. A következő lehetséges alkalmazási területeket írják le: minőség ellenőrzés, az aktív komponensek jellemzése, formula (összetétel) fejlesztés és a piacon található termékek összehasonlítása.

A harmadik nagyobb lehetséges alkalmazási terület a környezet védelem témájában adódik, melyre az elektronikus nyelvet nagy érzékenysége teszi képessé. Nehézfém ionok detektálásával foglakozott Di Natale és munkatársai [1995, 1996, 1997]. Szintén nehézfém ionok valamint ammónium és alkáli ionok elektronikus nyelvvel történő mérési lehetőségeit tárgyalja Mimendia és mtsai. [2007]. Az utóbbi szerzők az elektronikus nyelvet egy nagyobb környezetfigyelő rendszer részeként képzelik el.

Az elektronikus nyelvet többen is használták mikrobák detektálására [Soderstrom és mtsai. 2003], megkülönböztetésére [Soderstrom és mtsai. 2005] és fermentációs folyamatok nyomon követésére [Esbensen és mtsai. 2004, Pourciel-Gouzy és mtsai. 2008, Turner és mtsai. 2003, Vojinovic és mtsai. 2006]. Mivel a mikrobiológiai életfolyamatok során felszabaduló anyagcsere termékek az elektronikus nyelv szempontjából többnyire jól mérhető komponensek (savak) a müszer különösen alkalmas a feladatra. Ezen felül az élelmiszerek eltarthatóságának vizsgálata és mikrobák detektálása esetenként ugyan annak az éremnek két oldala.

\section{4Íz-kölcsönhatások az elektronikus nyelvvel kapcsolatban}

Toko és kutató csoportja egy általuk íz szenzornak (Taste Sensor) nevezett, az elektronikus nyelv definíciót teljes mértékben kielégítő müszert készítettek és vizsgáltak. Szerintük az íz szenzornak pontosan ugyan úgy kell viselkednie az egyes oldatokkal szemben, ahogy azt az emberi ízlelés tenné, vagyis konzisztens módon, hasonló íz-küszöb értékekkel és ami számunkra fontos, hogy az ember számára érzékelhető kölcsönhatásokat is érzékelve [Kobayashi és mtsai. 2010]. Egy ilyen kölcsönhatás például, hogy a keserü kávét cukorral (és tejjel) tesszük kevésbé keserűvé.

Az elektronikus nyelvvel kapcsolatban eddig leírt íz-kölcsönhatások jobbára a keserü íz elfedését, maszkolását vizsgálja és ezek szinte mindegyike gyógyszeripari alkalmazás. Az esetek igen jelentős részében a müszert egyfajta keserű detektorként használják és nem foglalkoznak a háttérben megbújó müködési mechanizmussal [Guhmann és mtsai. 2015, 
Haraguchi és mtsai. 2014, Henning 1916, Maniruzzaman és mtsai. 2015, Mennella és mtsai. 2013, Monteagudo és mtsai. 2014, Preis és mtsai. 2014, Wei és mtsai. 2015, Yi és mtsai. 2014]. Ennek egyik kézenfekvő oka, hogy az imént hivatkozott tanulmányok egy jelentős részében az íz-maszkolás fizikai úton történik, azaz a keserü összetevőt becsomagolják valamilyen gyomorban oldódó polimerbe például Eudragitba®.

A kölcsönhatás mibenlétével részletesebben foglakozó publikációk egyike Newman és munkatársainak müve [2015]. Kutatásukban Na-kazeinát hidrolizátumok keserüségét próbálták elfedni különféle édes és aromás anyagokkal, mint például szukralózzal vagy vanília aromával. Az elektronikus nyelv esetében az édesítőszerek keserüséget csökkentő hatását jól meg tudták figyelni, azonban az aromák íz-fedő hatásának kimutatására nem volt alkalmas a müszer.

Zakaria és mtsai. művében [2014] gyógyteák keserü ízének maszkolásával foglalkozik különböző adatfeldolgozási technikák elemzése mellett. Az íz-maszkolást úgy definiálja, hogy minél jobban eltér a maszkoló anyaggal kiegészített minta az eredetitől (minél könnyebb klasszifikációval megkülönböztetni őket egymástól), annál hatékonyabb a maszkolás. Ezzel csupán az a probléma merül fel, hogy nem foglalkozik a változás 'irányával' és így nem feltétlenül jó irányba módosítja a kiegészített minta ízét, hisz ezek alapján az akár még keserübb is lehet.

Choi és munkatársai [2014] részletesen vizsgálták különféle édesítőszerek (neoheszperidin-dihidro-kalkon, szacharóz, szukralóz és aszpartám) kölcsönhatását modell gyógyszerekkel (acetaminofen, ibuprofen, tramadol-hidroklorid, és szildenafil-citrát; egytől egyig 20 mM koncentrációban). Méréseik azt mutatták, hogy az íz-fedő anyagok hatása nem csak a koncentrációtól, de a maszkolni kívánt vegyülettől is függött, mely magába foglalja azt a megállapítást, hogy a kölcsönhatások vegyület páronként különböznek.

Ito és mtsai. [2013] egy Alpha Astree elektronikus nyelvvel dolgozott, melyhez egy kifejezetten gyógyszeripari mérésekhez kifejlesztett szenzor sort használt. Kinin és nyolc keserü ízü anti-hisztamin maszkolhatóságát vizsgálta aceszulfám-K és aszpartám édesítőszerekkel és méréseit érzékszervi elemzéssel is kiegészítette. A maszkoló hatást akkor tekintették sikeresnek, ha a keserü komponenst tartalmazó (aktív) és anélküli keveréket (placebó) az elektronikus nyelv nem különbözteti meg. Ezt az elektronikus nyelv szenzorai által kifeszített térben meghatározott euklideszi távolsággal jellemezték. A sikeresen maszkolt keverékek placebótól számított euklideszi távolsága 40 intenzitás egység volt, mely valóban elég kis különbség tekintve a müszer $\pm 10^{4}$ szélességü skáláját. A maszkolási eredmények erős korrelációt mutattak $(\mathrm{r}=0,97)$ az érzékszervi elemzés során kapott eredményekkel. Bár a cikk szerzői nem térnek ki rá, a közölt fökomponens elemzés ábrákból látszik, hogy a 
koncentrációk növelése konzisztensen azonos irányba módosította az elektronikus nyelv jeleit (azaz a koncentrációk balról jobbra növekedtek, vegyülettől függetlenül). Ez azért érdekes, mivel a cikkben elsőnek elkészített keserüségi skálát figyelembe véve az édesítő szerekkel kiegészített oldatoknak még keserübbnek kellene lennie. Feltehetően ez az oka, hogy az utolsó fejezetben bemutatott elektronikus nyelv - érzékszervi elemzés összevetést az aktív placebo minták euklideszi távolságokra alapozzák és nem nyers vagy származtatott (pl.: fökomponensek) szenzorjelekre.

Campbell és mtsai. [2012] egy Alpha Astree típusú elektronikus nyelvvel gyógyszer formulákat vizsgáltak. Céljuk a legjobb íz-maszkoló aroma anyag megtalálása volt. Kísérleteik során arra a következtetésre jutottak, hogy az egyes aroma anyagok eltérö mértékben voltak képesek hatni a formula ízére attól függően, hogy az aktív komponens szuszpenzióban vagy oldatban volt. Itt a különbségeket feltehetően az aktív (keserü) komponens hozzáférhetősége, oldottsága okozta.

Woertz és munkatársai [2011a] egy TS-5000Z típusú, japán fejlesztésű elektronikus nyelv segítségével értékelték 11 generikus és 3 saját fejlesztésű gyógyszerkészítmény ízét. Megközelítésük lényege, hogy a piacon már sikeresnek bizonyult termékek (az íz-maszkolás megfelelő és kipróbált) ízét próbálják lemásolni. Állításuk szerint a már kész formulák és az egyes potenciális íz-maszkoló anyagok ismeretében közelítőleg megtervezhető a megfelelő ízfedő képességgel rendelkező receptúra az elektronikus nyelv mérési eredményei alapján. Azonban a publikációban nem célirányosan módosítják az összetételt, hanem a már bevált összetétel komponenseiből készítettek változatokat és hasonlították az eredeti készítményhez. Ez a módszer inkább letapogatja a lehetséges összetétel változatokat, mint megjósolja, hogy egy adott összetevő koncentrációjának módosítása milyen ízbéli változást okoz.

Legin és munkatársai [2009] egy gyógyszer hatóanyag keserü ízének maszkolását vizsgálták. Ehhez felállítottak egy keserüségi skálát, melyet kinin oldatok hígítási sorozatára $\left(0,4-360 \mathrm{mgL}^{-1}\right)$ épített, többváltozós lineáris regressziós modellel értek el. Ezen a skálán értékelték kinin, Bitrex ${ }^{\circledR}$ (denatonium, egy keserü modell, a legkeserübbnek ismert vegyület) és az aktív hatóanyag oldatainak keserüségét. Ezek után az oldatokat kiegészítették szukralózzal, aszpartám és aceszulfám K keverékével vagy szőlőlével és megfigyelték az ízmaszkolást. A hatást egyrészt a korábban már említett placebo - aktív több dimenziós euklideszi távolságokkal értékelték, másrészt az íz-fedő anyagokkal kiegészített oldatok kinin keserüségét megbecsülték a korábban felállított modell segítségével. Mindkét értékelési módszer alapján a szőlőlé bizonyult a leghatékonyabb íz-maszkolónak. Fontosnak tartom megjegyezni, hogy a felhasznált maszkoló anyagok közül a szőlőlé volt az egyetlen, mely számottevő $\mathrm{pH}$ befolyásoló képességgel rendelkezett. A hatékony maszkolás lehet egyszerüen 
a mérőmüszerre gyakorolt erősebb hatás következménye, hisz az elektronikus nyelvek igen érzékenyen tudják a savas komponenseket mérni.

Egy igen érdekes munka került ki Nagamori és munkatársai [1999] keze közül. Kísérleteikben a sós $(\mathrm{NaCl})$ íz Na-glutamáttal történő elnyomását vizsgálták potenciometriás elektronikus nyelv segítségével. Készítettek egy sóssági skálát főkomponens elemzés segítségével. Eredményeik alapján a Na-glutamát gyengítette a mérhető sósságot.

Egy kompozit vezetőképes polimer-film bevonatú szenzorokkal felépített, impedimetriás elektronikus nyelvvel Riul és munkatársainak [2003] sikerült kimutatniuk $\mathrm{HCl}$ (1 mM) ízmaszkolását szacharózzal $(17,1$ - 102,6 g/L). Emellett sikeresen megkülönböztettek különböző ízzel rendelkező vegyületek híg oldatait víztől valamint ásványvizeket, és borokat egymástól. A szacharóz maszkoló képessége ebben a koncentrációban nem feltétlenül anyagi minőségétől, mint inkább mennyiségétől származhat.

Kobayashi és munkatársai [2010] az íz-maszkoló hatásra többféle lehetséges magyarázattal is szolgálnak:

- A keserü vegyületek hatása csökkenhet, ha az illető komponenseket komplexálják más anyagok. Ezt ciklodextrin esetében figyelték meg, ahol az elektronikus nyelv érzékenyebb volt a kinin keserüségét maszkoló hatásra, mint az emberi bírálók.

- Az oldatban található ellenionok semlegesítik a keserü komponens (pl.: kinin) töltését és ezáltal csökken a vonzás a töltött membrán felülethez.

- A cukrok (pl.: szacharóz) vélhetően kapcsolódnak a membrán felületéhez és mivel maguk meglehetősen hidrofil tulajdonságúak, ezért csökkentik a hidrofób (pl.: kinin) anyagok adszorpcióját a membránon, gyakorlatilag kiszorítják őket. Ez utóbbinak kissé ellent mond, hogy a cukrok potenciometriás mérése a mai napig nehézségekbe ütközik, holott az elképzelés alapján igen kiválóan kapcsolódnak a membránhoz és módosítják annak polaritását.

- Az olajok szelektíven elnyomják a keserü és fanyar komponensek ízét. Ezt feltehetően az okozza, hogy a hidrofób vegyületek a vizes fázisból az olajosba kerülnek és ezáltal az elektronikus nyelv szenzorok számára nem hozzáférhetőek.

Ugyanezen munkában a szerzők mellékesen említik, hogy egy bizonyos szenzor prototípusnál, ha az érzékelőt előzőleg $0,05 \%$ galluszsavba merítik, akkor az érzékennyé válik édes vegyületekre (glükóz, fruktóz és szacharóz 1M-os koncentrációban). Mindebből arra következtettek, hogy a galluszsav adszorbeálódott a szenzor membránjába és mint szelektív érzékenyítő hatott. A jelenséget felfoghatjuk ízfokozásnak is, hisz a korábban nehezen érzékelhető (kicsi szenzorjel különbséget produkáló) cukrok könnyebben mérhetővé válnak. 
Ízfokozásra való utalás egyedül ebben a cikkben található, a jelenséggel nem foglalkoztak eddig.

Az eddig bemutatott publikációk jól mutatják, hogy az elektronikus nyelv lehetséges alkalmazási területei igen szerteágazóak. Az íz-kölcsönhatásokat tekintve a keserü íz csökkentésével kapcsolatos munkák elsöprő többségben vannak. Azonban már ezekben a munkákban is helyenként feltünik, hogy a kölcsönhatások nem követik mindenhol az emberi érzékelést [Ito és mtsai. 2013]. Továbbá láthattuk, hogy az interakció függhet a koncentrációtól és a kölcsönhatásban résztvevő anyagoktól [Choi és mtsai. 2014]. Azt sem szabad elfelejteni, hogy a mérési eredményeket befolyásoló kölcsönhatások bárhol felléphetnek, ahol egynél több komponensü oldatokat mérnek és nem csak a keserü vegyületekkel kapcsolatban. A bemutatott munkák általában csak megállapítják a kölcsönhatás létét és erősségét például euklideszi távolságok alapján. A kölcsönhatás részleteivel (például a hatás az egyedi szenzorokon keresztül hogyan fejeződik ki a többváltozós elemzésekben) nem foglalkoznak és így a lehetséges következményeket sem tudják megállapítani. Egyes munkák [Nagamori és mtsai. 1999, Woertz és mtsai. 2011a] a kölcsönhatások additív természetéböl indulnak ki, azonban ennek vizsgálata még meglehetősen hiányos. 


\section{Cél}

Az elektronikus nyelvvel vizsgált oldatok elsöprő többsége egynél több összetevőből áll nem számítva ide az oldószert. Ebből kifolyólag az elektronikus nyelvvel végzett mérések ugyanekkora részében az oldott komponensek közötti kölcsönhatásokkal is számolni kell és a kölcsönhatások megértése szinte minden elektronikus nyelv mérési eredmény értelmezését érinti. Munkámban azt tűztem ki célul, hogy modell oldatok és néhány folyékony élelmiszer minta segítségével felderítsem az Alpha Astree elektronikus nyelvet érintő lehetséges ízkölcsönhatásokat és megállapítsam azok következményeit.

Az irodalomban található adatokra alapozva és azokat kiegészítve vizsgálataimat a lehető legszélesebb spektrumban kell folytatnom. Ennek érdekében az alábbi rész célokat tartottam szem előtt:

- A kölcsönhatások vizsgálatát ki kell terjeszteni minden alapízre és azok különféle kombinációira.

- A kölcsönhatásokat kvalitatív és kvantitatív módon szükséges jellemezni a szokásos többváltozós elemzések és az egyedi elektronikus nyelv érzékelők szintjén is.

- A cél elérésének érdekében létre kell hozni egy mérési módszert, mely minimalizálja az elektronikus nyelv ismert zavaró hatásait.

- A megfigyelt jelenségek alapján következtetéseket és javaslatokat fogalmazok meg, melyek a későbbi elektronikus nyelvvel végzett mérések tervezését és értelmezését segítik. 


\section{Anyagok és Módszerek}

\subsection{Az elektronikus nyelv}

\subsubsection{Az elektronikus nyelv felépítése és használata}

Méréseim során az Alpha M.O.S. (Toulouse, Franciaország) Alpha Astree 2 típusú potenciometriás elven müködő elektronikus nyelvét használtam [AlphaM.O.S. 2003] (5. ábra). A müszer lelke a mérőfej, mely 7 munkaelektródból (azonosítóik: ZZ, JE, BB, CA, GA, HA és JB), egy $\mathrm{Ag} / \mathrm{AgCl}$ referencia elektródból és egy keverőből áll. Ha párhuzamot vonunk az emberi íz-érzékeléssel, akkor ez az elem megfeleltethető az emberi nyelvnek.

Az érzékelősor egy automatikus mintavevő egységhez csatlakozik (Metrohm, USA), mely 16 mintatartó hellyel rendelkezik, tehát egy mérési alkalommal 16 minta mérhető le. A mintavevő végzi el a minták pozícionálását és a szenzorsor mozgatását.

A szenzorsor szolgáltatta jelek az elektronikus feldolgozó egységbe kerülnek, ahol a jelek elö-feldolgozása és digitalizálása történik és ez az egység kapcsolódik a számítógéphez. A szenzorjeleket egy $-10^{4}$-től $10^{4}$-ig tartó mértékegység nélküli, intenzitás skálán kapjuk, mely a szenzorok felületén mérhető potenciálnak feleltethető meg. A számítógépen futó AlphaSoft szoftver (ver. 12.4) gyüjti, tárolja és dolgozza fel az adatokat, valamint vezérli a mintavevőt és az elektronikus egységet.

Egy mérés kivitelezéséhez az AlphaSoft szoftverben egy szekvenciát kell összeállítani, mely leírja, hogy az egyes mintákat hányszor, milyen sorrendben és módszer alapján mérjen meg a müszer. A módszer a mintavételezés időtartamát (esetemben mindig $120 \mathrm{~s}$ ) gyakoriságát (1 s) és a keverő elem sebességét (4 egység egy 15 fokozatú skálán) határozza meg. A gyártó által javasolt mérési eljárásban az egyes mérendő minták közé egy-egy tisztítást kell beiktatni, ami az egyik mintatartó helyen elhelyezett desztillált vizet jelent, melyben a szenzorok 15-20 s-ot tartózkodnak viszonylag magas keverőelem fordulatszám mellett (6 egység). Ideális esetben minden minta 'saját' tisztítással rendelkezik, ami azt jelenti, hogy a 16 mintahelyből csak 8 helyre kerül lemérendő minta. Egyes esetekben elkerülhetetlen nagyobb számú minta mérése, ilyenkor a tisztításra használt helyek számát kell ésszerü mértékben csökkenteni. 


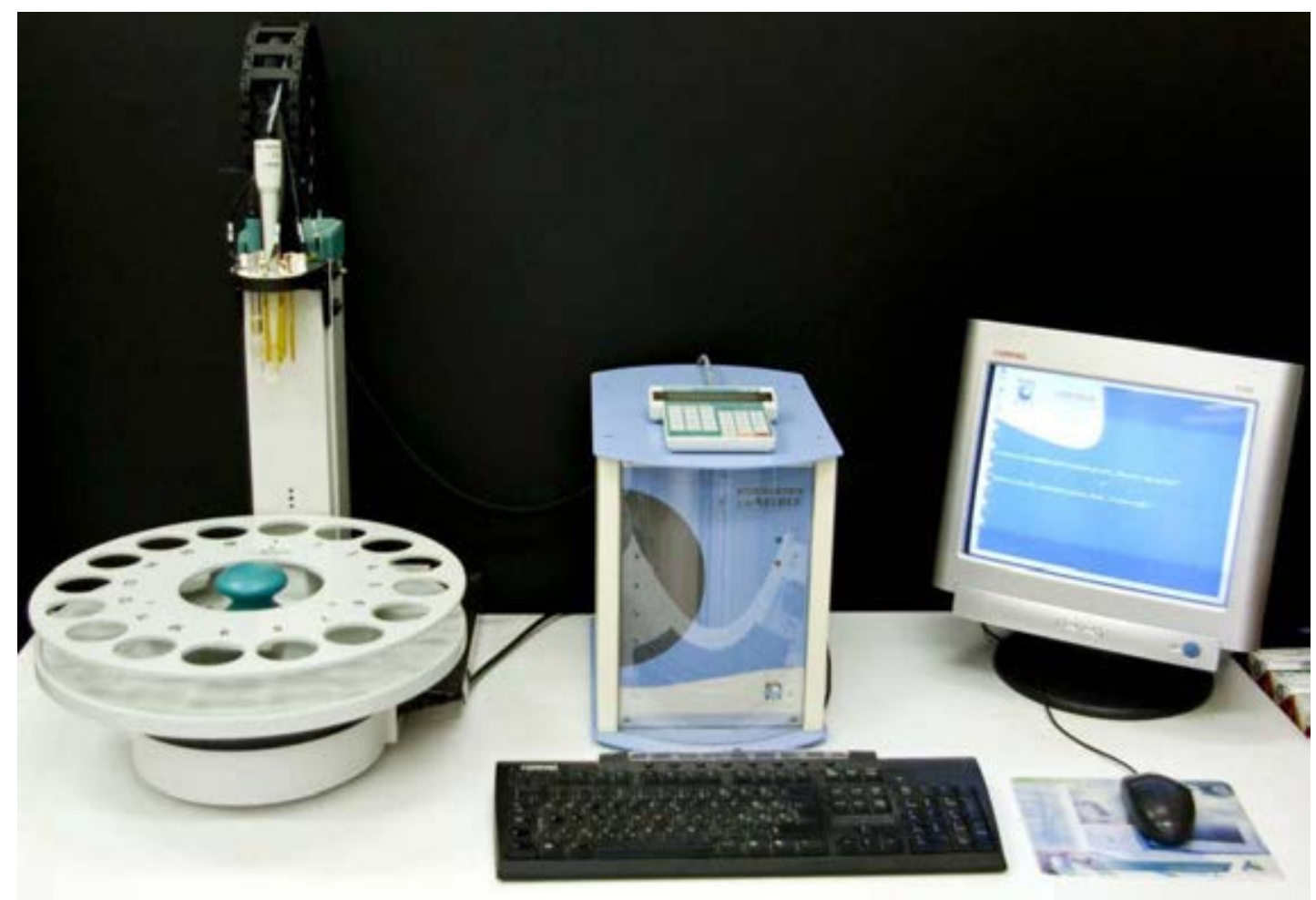

5. ábra Az Alpha Astree elektronikus nyelv

Az érzékelők a mérések közötti periódusban szárazak, ezért mérés elött szükséges a mérendő minta mátrixszal (esetemben desztillált víz) telíteni a szenzorokat. Ezt a folyamatot kondicionálásnak nevezik, hozzá híg $(0,01 \mathrm{M})$ sósavat használtam a gyártó ajánlása szerint. A kondicionálás során a szenzorok felülete hidratálódik, közben a müszer folyamatosan méri a szenzorjeleket. Az érzékelők kondicionáltságát a szenzorjelek kellő stabilitása és szintje jelzi, ekkor következik a kalibráció. A kalibrációhoz szintén 0,01 M-os HCl-ot használtam (a gyártó ajánlásának megfelelően) és ennek során minden szenzornak egy előre definiált jelszintre történő beállítása történik. Ez a gyakorlatban egy elektronikus offszet eltolást jelent, tehát a szenzorok egy egy-pontos kalibráción mennek keresztül. Bár lehetséges lenne két pontra kalibrálni egy második kalibráló oldat kiválasztásával, azonban az elektronikus nyelv szenzorok az eltérő vegyületekre eltérő érzékenységgel rendelkeznek így a helyes érzékenység csak az adott oldatpárra lenne igaz [Kovács 2012]. A kalibráció sikeres, ha az egyes szenzorok jelei kellően megközelítik a nekik megfelelő kalibrációs értéket és ez stabilan tartják is mintavételezés alatt és minták között is. Ha minden feltétel teljesül, a kalibráció sikeres és kezdődhet maga a mérés. Az elektronikus nyelvet a mérések megkezdéséhez minden tekintetben a gyártó utasításainak megfelelően készítettem elő [AlphaM.O.S. 2003, 2006]. 


\subsubsection{Az elektronikus nyelv szenzorjel stabilitása}

Az elektronikus nyelv egy mindmáig csak kevéssé kutatott, mégis igen fontos mérést megnehezítő tulajdonsága, hogy a munkaszenzorok a mérési alkalmak között és sajnos valamilyen mértékben a mérés alatt is ún. drift (csúszás) jelenséget mutatnak [Kovács 2012]. A drift hatása és egyben definíciója is, hogy egy szenzor még azonos előkészítő műveletek után is (tehát kalibrációt követően) csak némi különbséggel képes ugyanazon oldat, időben eltérő mérési eredményét reprodukálni. A drift oka a szenzorok érzékenységének változása, melyet szennyeződés, elhasználódás és a mintaoldatok egyes összetevőinek tartós adszorpciója is okozhat [Artursson és mtsai. 2000]. Holmin és munkatársai lineáris drift korrekciós módszerekkel igyekeztek a csúszás okozta hatásokat kiküszöbölni [Holmin és mtsai. 2001]. A technika lényege, hogy a mérési alkalmak során állandó referencia oldatokat jelölnek ki, melyek szenzorjeleinek azonosnak kellene lennie minden mérésnél, ha nem lenne drift. A referencia oldatok jelmintázatának csúszása jellemzi a drift irányát és nagyságát és lehetőséget ad a korrekcióra. A módszer implicit módon feltételezi, hogy a drift az egyes minták esetében azonos irányú és nagyságú. A drift okozta hibák minimálisra csökkentésének legjobb módja, ha az összehasonlítani kívánt mintákat egy mérési alkalommal mérjük meg. Arra az esetre, ha mégis szükséges eltérő időben végzett méréseket összevetni, kidolgoztam egy mérési módszert és matematikai korrekciót (5.3.1 fejezet), mely mind a mérésen belüli, mind a mérések közötti driftet igyekszik kompenzálni. A módszer lényege, hogy beiktattam egy 'centrum' mintát, melyet minden mérés elején és végén is lemértem. A centrum mintát igyekeztem minden méréshez kompatibilissé tenni azzal, hogy a vizsgált alapízeknek megfelelő vegyületek mindegyikének alacsonyabb koncentrációjú keveréke. Mivel a centrum minta a mérés elején és végén is szerepel, a kapott szenzorjelek megváltozásából következtethettem a mérés során végbement driftre, valamint az eltérő időben készült méréseket is összevethettem. A korrekció ellenőrzéséhez és következtetéseim megfogalmazásához minden mérésben a mérések elején és végén lemértem egy tiszta desztillált vizet tartalmazó mintát is (DV). Helyes korrekció esetén a mérés két 'végén' elhelyezkedő desztillált víz minta jeleinek hasonlónak kell lennie.

\subsubsection{Az elektronikus nyelv mérések beállításai}

Következtetéseimet többféle szenzorsorral készült mérésekre alapoztam, mivel úgy gondolom a lehetséges kölcsönhatások feltérképezésére így nyílik leginkább lehetőség. A legtöbb esetben a legújabb 2013-ban beszerzett, a gyártó által élelmiszer mintákhoz ajánlott szenzorsort használtam. Amennyiben külön nem jelöltem, akkor ezt a szenzorsort használtam a méréshez. Ez a szenzorsor a méréseim előtt és alatt más, a munka témájához nem kapcsolódó mintákhoz nem került felhasználásra. Ezen felül egyes tézisek megalapozottabb 
bizonyításához korábbi méréseket is felhasználtam, mely eltérő szenzorsorokkal készültek, ezek a következők voltak:

- Sor2007 - élelmiszerek méréséhez ajánlott szenzorsor, szenzorok: ZZ, BA, BB, CA, GA, HA, JB

- Sor2012 - élelmiszerek méréséhez ajánlott szenzorsor, szenzorok: ZZ, BB, CA, GA, HA, JB

- Specifikus szenzorsor: Ennek a szenzorsornak egyes érzékelői a gyártó szerint rendelkeznek némi specificitással bizonyos alapízekre. SRS - savanyú; BRS keserü; UMS - umami; STS - sós; SWS - édes. Ezen felül a sorban két alapízhez nem kötött globális érzékenységü szenzor is volt az SPS és a GPS.

A modell oldatokkal végzett kísérleteimben kétféle mérési szekvenciát alkalmaztam. Az egyik esetben a szekvencia öt modell oldatot a korrekcióhoz szükséges centrum és desztillált víz mintát (DV) és mindegyikhez saját tisztítást tartalmazott (1. táblázat 2. oszlop). Ezt a szekvenciát tekinthetjük a klasszikus mérési szekvenciának is, mivel a gyártó is ehhez hasonlót ajánl és a tanszéken folytatott korábbi munkáinkban is ehhez hasonlókat használtunk [AlphaM.O.S. 2003, Kovács és mtsai. 2010, Kovács és mtsai. 2011, Kovács és mtsai. 2009, Szöllősi és mtsai. 2012].

A másik esetben (kibővített elrendezés) tíz modell oldatot mértem le a korrekcióhoz szükséges oldatokkal együtt, így itt három mintához tartozott egy tisztítás (1. táblázat 3. oszlop). A müszer érzékelői minden minta oldat után a mintához tartozó tisztító oldatba került, mely a szekvenciában sorban előtte található első tisztító folyadék.

A mérési sorrend mind a két szekvencia esetében a következő volt: Az elektronikus nyelv elsőnek a DV mintát mérte 9 ismétlésben, majd a centrum mintát 9 ismétlésben. Ezek után a modell oldatok következtek véletlenszerü sorrendben, de összesen 9 ismétlésben. A mérés végén újra a centrum minta kerül 9-szer lemérésre, majd a DV minta 9 ismétlésben.

A bemutatott mérési szekvenciától néhány esetben eltértem. Ilyenkor minden esetben a klasszikus elrendezéshez hasonló mérési sorrendet használtam (tisztítás, minta1, tisztítás, minta $2 . .$.$) referencia oldatok nélkül. A mintákat egymás után, sorban mértem és az ismétlések$ (itt is kilenc) egy 'teljes kör' után következtek.

A másik eset (csak egy ilyen volt) mikor a centrum mintát kihagytam a mérésből melynek oka, hogy a mérésből a citromsavat, NaCl-ot vagy Na-glutamátot teljesen ki akartam hagyni, mivel ekkor azt is teszteltem a mérésben, hogy az említett vegyületek puszta jelenléte hatással van-e a mérésben résztvevő más minták elektronikus nyelvvel kapott szenzorjeleire. 
1. táblázat Minták pozíciói az automata mintavevőben.

\begin{tabular}{lll}
\hline Minta pozíció & klasszikus szekvencia & kibővített szekvencia \\
\hline 1 & tisztítás (DV) & tisztítás (DV) \\
2 & DV & DV \\
3 & tisztítás (DV) & Centrum \\
4 & Centrum & modell oldat 1 \\
5 & tisztítás (DV) & tisztítás (DV) \\
6 & modell oldat 1 & modell oldat 2 \\
7 & tisztítás (DV) & modell oldat 3 \\
8 & modell oldat 2 & modell oldat 4 \\
9 & tisztítás (DV) & tisztítás (DV) \\
10 & modell oldat 3 & modell oldat 5 \\
11 & tisztítás (DV) & modell oldat 6 \\
12 & modell oldat 4 & modell oldat 7 \\
13 & tisztítás (DV) & tisztítás (DV) \\
14 & modell oldat 5 & modell oldat 8 \\
15 & - & modell oldat 9 \\
16 & - & modell oldat 10 \\
\hline
\end{tabular}

\subsection{Minta oldatok}

A modell oldatokban használt anyagokat és koncentrációjukat az érzékszervi analízis számára készült szabvány [ISO/FIDS_3972:2011 2011] alapján határoztam meg. A szabványban a bírálók íz-felismerésének értékelésére használt tesztben (8. pont) a következő anyagok és koncentrációk olvashatóak: citromsav 0,28 g/L, NaCl 1,19 g/L, Na-glutamát 0,29 $\mathrm{g} / \mathrm{L}$, koffein 0,195 g/L és szacharóz 5,76 g/L. Kísérleteimben ezeket a koncentrációkat alkalmaztam. A 2. táblázat a modell vegyületek általam alkalmazott koncentrációit és az adott vegyület íz-küszöb értékeit tünteti fel, mind emberekre mind az elektronikus nyelvre vonatkoztatva az elektronikus nyelv gyártója szerint. Amennyiben a mérések kiértékelésénél nem jelöltem külön, úgy az adott modell oldat koncentrációja az anyagnak megfelelő 2 . táblázatban látható koncentrációban szerepelt a mérésben. Koncentráció sorozatok mérése esetén pedig ettől a koncentrációtól tértem el hígabb és töményebb irányba. Ezek a koncentrációk mind az emberi érzékelés mind az elektronikus nyelv szempontjából már jól érzékelhetőek [AlphaM.O.S. 2002a], viszont kellően alacsonyak ahhoz, hogy a minta áthordás és a memória effektus a lehető legkisebb mértékben befolyásolja a mérési eredményeket [Kovács 2012].

Az összehasonlítás során nemcsak egymáshoz viszonyítottam a mintákat, hanem egy semlegesnek tekintett mintához is. Erre a célra kétféle oldatot használtam: desztillált vizet 
melyet a szövegben és ábrákon 'DV' jelöl és egy minden modell anyagot (citromsav 0,089 $\mathrm{g} / \mathrm{L}, \mathrm{NaCl}$ 0,376 g/L, Na-glutamát 0,092 g/L, koffein 0,062 g/L és szacharóz 1,821 g/L) tartalmazó keveréket melyet 'centrum' mintaként említek. A centrum minta összetételének meghatározásánál fontos szempont volt, hogy ne legyen a minta túl intenzív, az elektronikus nyelv számára azonban biztosan jól mérhető legyen. Mivel a szenzorjel a koncentráció logaritmusával arányos (3.2.3 fejezet), ezért a fent leírt modell oldat koncentrációk 3,16-od részét vettem, ami egy tízes alapú logaritmikus skálán az eredeti koncentrációknak a fele $\left(\log _{10}(3,16)=0,4997\right)$.

2. táblázat Modell oldatok koncentrációi és íz-küszöb értékei.

\begin{tabular}{lccccc}
\hline \multirow{2}{*}{$\begin{array}{l}\text { Vegyületek } \\
\text { Koncentráció*, } \\
\mathrm{g} / \mathrm{L}\end{array}$} & $\begin{array}{c}\text { Koncentráció, } \\
\mathrm{M}\end{array}$ & $\begin{array}{c}\text { Centrum } \\
\text { koncentráció, } \\
\mathrm{g} / \mathrm{L}\end{array}$ & $\begin{array}{c}\text { Emberi } \\
\text { íz-küszöb**, }\end{array}$ & $\begin{array}{c}\text { Elektronikus nyelv } \\
\text { íz-küszöb**, }\end{array}$ \\
\hline citromsav & 0,280 & 0,0015 & 0,0885 & 0,0001 & 0,0000001 \\
$\mathrm{NaCl}$ & 1,190 & 0,0204 & 0,3763 & 0,001 & 0,000001 \\
$\mathrm{Na-glutamát}$ & 0,290 & 0,0017 & 0,0917 & 0,0005 & 0,0001 \\
koffein & 0,195 & 0,0010 & 0,0617 & 0,0005 & 0,0001 \\
szacharóz & 5,760 & 0,0168 & 1,8215 & 0,00065 & 0,00001 \\
\hline
\end{tabular}

*[ISO/FIDS_3972:2011 2011]**[AlphaM.O.S. 2002a]

A DV minta gyakorlatilag az íz-mentes állapotot jelzi, a centrum minta pedig egyfajta összegzett, minden hatást magába foglaló mintát. Ez utóbbi két minta további haszna, hogy felhasználhatóak utólagos matematikai korrekciók elvégzésére és a mérés jóságának ellenörzésére is.

Modell oldataimból két és háromkomponensű kombinációkat is megvizsgáltam az elektronikus nyelvvel. A kombinációk jelölésében a komponenseket rendre feltüntettem '|' jellel elválasztva, így például a citromsav és a $\mathrm{NaCl}$ keverékét 'citromsav| $\mathrm{NaCl}$ ' ként jelöltem. A kombinált oldatoknál néhány esetet kivéve mindig a 2. táblázat koncentrációit alkalmaztam. Az egyik kivételes esetben koffein több koncentrációjú sorozatát mértem le tisztán és Naglutamáttal kiegészítve. A koffein koncentrációk 1,95; 3,47;6,17;10,96;19,5 g/L voltak a hozzáadott Na-glutamát mennyisége $0,29 \mathrm{~g} / \mathrm{L}$.

NaCl-ból és koffeinből készítettem egykomponensü koncentráció sorozatot is, mivel egyes következtetéseimet becslő modellek elkészítésével tudtam megfogalmazni. A koncentrációkat tízes alapú logaritmikus skálán határoztam meg úgy, hogy a fent leírt modell oldat koncentráció a 'középső' (medián) koncentráció legyen. Ennek megfelelően az alábbi 
oldatokat készítettem el: $\mathrm{NaCl}: 0,00119 ; 0,0119 ; 0,119 ; 1,19 ; 11,9$ g/L; Koffein: 0,00195; 0,$0195 ; 0,195 ; 1,95 ; 19,5 \mathrm{~g} / \mathrm{L}$

A citromsav és $\mathrm{NaCl}$ viszonyában, valamint a $\mathrm{NaCl}$ és Na-glutamát kölcsönhatásainak elemzéséhez a két modell vegyület több féle koncentráció kombinációi voltak jelen. Ezen esetekben is a 2. táblázatban látható koncentrációk képezték a közepes koncentrációt és ehhez képest tízszeres valamint tized akkora koncentrációkat alkalmaztam. Az egyes vegyületek koncentrációit az ábrázolás során A, B, C-vel (először a citromsavnál majd a Na-glutamátnál) és 1, 2, 3-mal $(\mathrm{NaCl})$ jelöltem, így például a közepes koncentrációk jele a 'B2' lett. Törekedtem arra, hogy az összehasonlítandó minták egy mérésben, egyszerre legyenek jelen, azonban így is kénytelen voltam az összes lehetséges kombinációból egyet kihagyni, hogy a szükséges kontroll minták (DV, centrum, tiszta komponensek) is jelen lehessenek a mérésben. Úgy gondolom, hogy ez a kihagyás nem befolyásolja hátrányosan a következtetéseim helyességét, mivel a kihagyott keverék az egyik komponens leghígabb, míg a másik komponens legtöményebb koncentrációját tartalmazta és várhatóan a kis koncentrációban jelenlévő komponens nem tudott volna számottevő hatást kifejteni, (korábbi mérési tapasztalatokból kiindulva) mivel a szenzorok a tömény komponens által telítésbe kerülnek.

Az édes és keserü ízü vegyületek különös fontossággal bírnak az elektronikus nyelv szempontjából, mivel kémiailag igen sokféle vegyületről van szó és az íz-maszkolás leggyakoribb célja a keserü íz elfedése. Ebből az okból nem csak koffeint és szacharózt, hanem kinint és aszpartámot is megvizsgáltam tisztán és kettős kombinációkban is (koffein 0,195 g/L, szacharóz 5,76 g/L kinin 0,00269 g/L, aszpartám 0,0288 g/L). A kinin koncentrációt az emberi íz-küszöb értékének megfelelően határoztam meg [Mojet és mtsai. 2005]. Az aszpartám az alkalmazott (5,76 g/L) szacharózzal ekvivalens édességü koncentrációban került a mérésbe [Magnuson és mtsai. 2007].

Vizsgálataimba bevontam élelmiszer mintákat is:

- Kereskedelmi forgalomból származó 100\%-os paradicsomlevet, mely tartalmazott hozzáadott NaCl-ot és citromsavat. A paradicsomléből koncentráció sorozatot készítettem, mivel a koncentráció interakciókra gyakorolt hatását vizsgáltam. A koncentrációkat mL/L egységben adom meg, mivel ez felel meg a leginkább a dolgozatban használt g/L koncentrációnak. Az egyes koncentrációk tízes alapú logaritmus szerint következnek és a következőek voltak: 0,$01 ; 0,1 ; 1 ; 10 ; 100$ $\mathrm{mL} / \mathrm{L}$.

- Felhasználtam egy 2009-ben lemért szójaital hígítási sor eredményeit. Az ital kereskedelmi forgalomból származott. Koncentrációi: 0,0001 - $1000 \mathrm{~mL} / \mathrm{L}$, tízszeres koncentrációs lépésekben követve egymást [Kovács és mtsai. 2009]. 
- Felhasználtam továbbá két kereskedelmi forgalomból származó 100\%-os almalé eredményeit (2012). Az almalevek tízszeres hígításban voltak a mérésben tisztán, valamint 5,0 g/L NaCl-dal kiegészítve, tehát összesen négy minta volt a mérésben.

- Egy másik almalével végzett mérésben (2010) egy kereskedelmi forgalomból származó 100\%-os almalevet mértem tisztán és glükóz - fruktóz 1:3 arányú keverékével kiegészítve. Az almalé tízszeres hígításban volt, a hozzáadott cukor keverék mennyisége a következők voltak: $1 ; 2,5 ; 5 ; 10 ; 20 \mathrm{~g} / \mathrm{L}$

\subsection{Statisztikai módszerek}

\subsubsection{Korrekció}

Mivel egy-egy mérés meglehetősen hosszú időt vesz igénybe ( 4 óra) ezért elkerülhetetlen a szenzorjelek fent leírt driftje [Kovács 2012]. Ezt a driftet a mérés elején és végén lemért centrum minta segítségével mértem és korrigáltam a 6 . ábra által szemléltetett mértékben, feltételezve, hogy a drift egy mérési alkalmon belül lineáris. A drift korrekcióhoz meghatároztam a centrum minta (az ábrán pirossal jelölve) mérési alkalom elején lemért kilenc ismétlésének és a végén lemért kilenc ismétlésének érzékelőnkénti átlagát, majd ennek különbségét, azaz minden szenzorhoz tartozott egy korrekciós érték. A kapott különbségekkel korrigáltam az egyes minták eredményeit, méghozzá a mérési sorrendjük szerinti mértékben, ezt jelöli az ábra alsó zöld sávja. A mérés elején lemért mintákat kisebb mértékü korrekciónak vetettem alá, mint a mérés végén lemérteket. A korrekció mechanizmusából adódóan, mivel minden mintát a centrum minta első előfordulásához korrigáltam, a DV mintából pedig ez előtt is található egy (az ábrán fekete) ezért a korrekció előjele itt ellentétes.
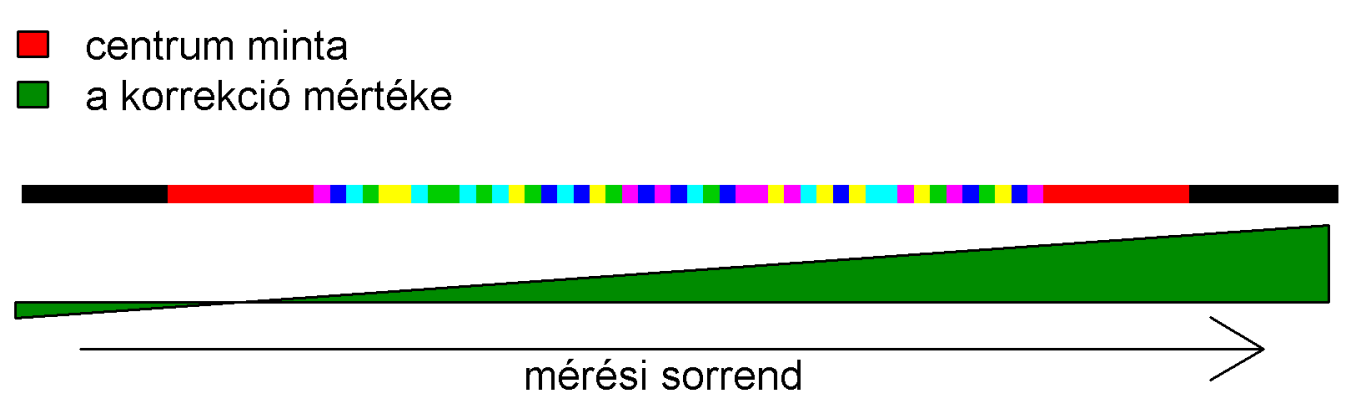

6. ábra A drift korrekció mintákra alkalmazott mértékének szemléltetése.

Amennyiben eltérő mérési alkalmak során készült eredményeket vetettem össze, úgy a fenti korrekción kívül és után, minden minta jeléből kivontam a centrum minta átlag jelét, ezzel a mérések közötti 'offset' jellegü hibát korrigáltam. A korrekció sikerességét a minden mérés elején és végén lemért DV mintákkal ellenőrizztem. 
$\mathrm{Az}$ elektronikus nyelv mérési eredményeit $\mathrm{R}$-project segítségével értékeltem ki [R Development Core Team 2012].

\subsubsection{Az adatok felépítése}

A mérési eredmények minden esetben egy 8 oszlopot és minták száma $\times 9$ (ismétlések) számú sort tartalmazó mátrixba kerültek. Az első oszlop a minta nevét tartalmazta, pl.: centrum, $\mathrm{NaCl}$. A további oszlopok az elektronikus nyelv szenzorok által mért mértékegység nélküli intenzitás értékeket tartalmazták.

\subsubsection{Minták közötti különbség: t-próba és euklideszi távolság}

Két mintát az elektronikus nyelv szempontjából akkor tekintettem különbözőnek, ha legalább egy szenzor eredményei alapján szignifikáns különbséget lehetett kimutatni kétmintás nem egyenlő szórásokat feltételező t-próba segítségével (Welch-próba, p<0,01). A minták közötti különbség nagyságát a szignifikáns különbéget mutató szenzorok által kifeszített térben meghatározott, átlagos euklideszi távolsággal jellemeztem. A minták közötti különbségek euklideszi távolsággal történő jellemzését az elektronikus nyelv gyógyszeripari alkalmazásainál is használták már [Ito és mtsai. 2013].

\subsubsection{Diszkriminancia elemzés}

Az elektronikus nyelv eredményeit legtöbbször diszkriminancia elemzésnek vetettem alá. A diszkriminancia elemzés (DA) előnye, hogy úgy transzformálja a szenzorjelek által meghatározott hét dimenziós teret, hogy a minták közötti különbségeket kiemeli, míg az azonos mintán belüli szórás hatását csökkenti a modellben. Az így kapott látens változó tér változóit root-oknak nevezzük, melyek közül az első hordozza a legtöbb csoportok közti információt, majd a további rootok rendre egyre kevesebbet. Ennek köszönhetően az új térben ábrázolt mintapontok vizualizálhatóvá válnak, hisz többnyire elegendő csak az első 3 rootot ábrázolni. A minta csoportok diszkrimináns térbeli elhelyezkedése jellemzi a minták hasonlóságát, nevezetesen minél jobban különbözik két minta, annál távolabb helyezkednek el pontjaik a diszkrimináns térben egymástól. A diszkriminancia elemzés során létre jön egy modell, mely egyrészt tartalmaz egy modell egyenletet, mely a kezdeti változókat leképezi az új látens változókra. A modellbéli koefficiensek jellemzik a kezdeti változók (elektronikus nyelv szenzorok) és a látens változók (rootok) közötti korreláció mértékét és irányát. A diszkrimináns modell ezen felül a modellbe vetített adatokat besorolja valamilyen a modell építésekor megadott csoportba. Ennek megfelelően a kezdeti adatokat két részre osztva (kalibráció, becslés) ellenőrizhető a modell robosztussága, mivel a becsült mintákról ez esetben tudjuk, hogy mi a helyes besorolása. Esetemben a két részre osztás úgy történt, hogy a teljes adathalmazból kivettem egy mérési eredményt (egy sor az adatmátrixból), felépítettem a 
modellt a 'maradék' adatokból, majd a kivett elemet a modellbe vetítve ellenőriztem a besorolás helyességét. Ezt a technikát leave-one-out módszernek hívják [Brereton 2009]. A becslést és annak segítségével egy modellt úgy is ellenőrizhetünk, hogy ugyanazokat a mintákat egymástól függetlenül kétszer is lemérjük, majd az egyik mérés eredményei alapján készült diszkriminancia modellel megbecsüljük a másik mérés mintáinak csoport besorolását. A helyes csoportba sorolás aránya felvilágosítást ad a modell robosztusságáról és/vagy a mérés reprodukálhatóságáról.

\subsubsection{Parciális legkisebb négyzetek regressziója}

A parciális legkisebb négyzetek regressziója (Partial Least Squares, PLS) egy független változó együttes (elektronikus nyelv szenzorjelek) segítségével készít egy becslő modellt egy függő változóra, jelen dolgozatban ez mindig koncentrációt jelent. A modell optimalizálása során a független változókat úgy bontja sajátértékeire és saját vektoraira, hogy a saját vektorok maximálisan korreláljanak a függő változóval. A módszer optimális megoldást nyújt arra, hogy az elektronikus nyelv adatokból a lehető legtöbb információt felhasználja és a függő változót a legjobban becsülje [Næs és mtsai. 2002]. A PLS modellek építésekor a koncentrációkat logaritmikusan transzformáltam (log10), mivel az elektronikus nyelv szenzorjelek és adott vegyület oldatának koncentrációja között az összefüggés logaritmikus jellegü [Kinnamon és mtsai. 1992, Vlasov és mtsai. 2002, Yasuura M. és mtsai. 2014].

\subsection{Minták és mérési módszerek összefoglalása}

A vizsgálataim során lemért minták és mérési technikák, valamint az azokból származó mérési eredmények könnyebb összevethetősége érdekében röviden összefoglalom, mely eredményekhez, mely anyagokat és módszereket alkalmaztam.

\subsubsection{Az alapízek vizsgálatához}

Egykomponensű modell oldatokat (melyek az alapízeknek megfelelő vegyületekből készültek) mértem a 2. táblázatban látható koncentrációkban a klasszikus szekvenciával (1. táblázat) két egymástól független alkalommal. A nyers adatokat korrekciónak vetettem alá. Az eredményeket t-próbával és diszkriminancia elemzéssel elemeztem és becsültem.

\subsubsection{A citromsav és a $\mathrm{NaCl}$ interakciójának vizsgálatához}

Kétkomponensü modell oldatokat (melyek az alapízeknek megfelelő vegyületekből készültek, 2. táblázat) mértem a kibővített szekvenciával (1. táblázat), továbbá citromsav és $\mathrm{NaCl}$ különböző koncentrációjú keverékeit (citromsav: 0,028; 0,28;2,8 g/L; NaCl: 0,119; $1,19 ; 11,9 \mathrm{~g} / \mathrm{L})$ elemeztem szintén a kibővített szekvenciával. Az elemzésekhez felhasználtam $\mathrm{NaCl}$ hígítási sorának $(0,00119 ; 0,0119 ; 0,119 ; 1,19 ; 11,9 \mathrm{~g} / \mathrm{L})$ mérési eredményeit is, melyet 
a klasszikus szekvenciával mértem le. A nyers adatokat korrekciónak vetettem alá. A mérési eredményeket diszkriminancia elemezéssel és PLS regresszióval számoltam ki. Az elemzésekben felhasználtam a 6.0 fejezetben létrehozott lineáris diszkriminancia modelleket is.

\subsubsection{A NaCl és a Na-glutamát interakciójának vizsgálatához}

A kétkomponensü modell oldatok (2. táblázat) eredményeit itt is felhasználtam, továbbá ugyanezen modell vegyületek három komponensü változatait is, melyet a kibővített szekvenciával (1. táblázat) mértem le. Ezen felül Na-glutamát és $\mathrm{NaCl}$ különböző koncentrációjú keverékeit (Na-glutamát: 0,029;0,29;2,9 g/L; NaCl: 0,119;1,19;11,9 g/L) mértem a kibővített szekvenciával. Az elemzésekhez felhasználtam $\mathrm{NaCl}$ hígítási sorának $(0,00119 ; 0,0119 ; 0,119 ; 1,19 ; 11,9 \mathrm{~g} / \mathrm{L})$ mérési eredményeit is, melyet a klasszikus szekvenciával mértem le. A nyers adatokat korrigáltam. A mérési eredményeket diszkriminancia elemzésnek és PLS regressziónak vetettem alá. Az elemzésekben felhasználtam az 6.0 fejezetben létrehozott diszkriminancia modelleket is.

\subsubsection{A koffein és a szacharóz interakcióinak vizsgálatához}

A kétkomponensű modell oldatok mérési eredményein túl felhasználtam koffein, szacharóz, kinin és aszpartám tiszta és kombinált oldatainak (koffein 0,195 g/L, szacharóz 5,76 g/L kinin 0,00269 g/L, aszpartám 0,0288 g/L) kibővített szekvenciával (1. táblázat) készült mérési eredményeit, továbbá koffein különbözö koncentrációjú $(0,00195 ; 0,0195$; 0,195; 1,95; 19,5 g/L) sorozatát a klasszikus szekvenciával lemérve. A nyers adatokon korrekciót hajtottam végre. Az adatokat diszkriminancia elemzésnek vetettem alá és az elkészült diszkriminancia modellekkel becsléseket is végeztem.

\subsection{4 Ízfokozás és íz-maszkolás vizsgálatához}

Ehhez a fejezethez a két és három komponensü alapízeknek megfelelő vegyületekből készült modell oldatok kibővített szekvenciával mért eredményeit használtam fel természetesen korrekció után. Ezen felül felhasználtam két, kereskedelmi forgalomból származó 100\%-os almalé eredményeit, melyeket 2012-ben mértem le. Az almalevek tízszeres hígításban voltak jelen a mérésben tisztán, valamint $5 \mathrm{~g} / \mathrm{L} \mathrm{NaCl}$-dal kiegészítve. Az eredmények kiértékelésénél diszkriminancia elemzést használtam.

\subsubsection{Interakciók koncentráció függésének vizsgálatához}

Egy és kétkomponensű alapízeknek megfelelő vegyületekből készített modell oldatok eredményeit használtam elemzéseimhez (rendre a klasszikus és a kibővített szekvenciát használva), továbbá koffein hígítási sorát $(1,95 ; 3,47 ; 6,17 ; 10,96 ; 19,5 \mathrm{~g} / \mathrm{L})$ tisztán és 0,29 g/L Na-glutamáttal kiegészítve a kibővített szekvenciával lemérve. A nyers adatokat 
korrekciónak vetettem alá. Ezeken kívül felhasználtam kereskedelmi forgalomból származó 100\%-os paradicsomlé hígítási sorának $(0,01 ; 0,1 ; 1 ; 10 ; 100 \mathrm{~mL} / \mathrm{L})$ kibővített szekvenciával mért eredményeit, egy 2009-ben lemért kereskedelmi forgalomból származó szójaital hígítási sor eredményeit $(0,0001-1000 \mathrm{~mL} / \mathrm{L}$ tízszeres koncentrációs lépésekben) és egy 2010-ben lemért kereskedelmi forgalomból származó 100\%-os almalé tiszta valamint glükóz és fruktóz 1:3 arányú keverékével kiegészített mintáit. Az almalé tízszeres hígításban volt ez utóbbi esetben, a hozzáadott cukor keverék mennyisége: 1; 2,5; 5; 10; 20 g/L. Az elemzésekben a mérési eredmények egyszerü összehasonlítását alkalmaztam.

\subsubsection{Interakció mérési minták között}

A következtetéseket ebben az esetben az egykomponensü alapízeknek megfelelö vegyületekből készített modell oldatok (klasszikus szekvencia) mérési eredményeire, $\mathrm{NaCl}$ hígítási sorának $(0,00119 ; 0,0119 ; 0,119 ; 1,19 ; 11,9 \mathrm{~g} / \mathrm{L} ;$ klasszikus szekvencia) mérési eredményeire, továbbá a citromsav és $\mathrm{NaCl}$ (citromsav: 0,028;0,28;2,8 g/L; $\mathrm{NaCl}: 0,119$; 1,19; 11,9 g/L, kibővített szekvencia), valamint Na-glutamát és $\mathrm{NaCl}$ (Na-glutamát: 0,029; 0,29; 2,9 g/L; $\mathrm{NaCl}: 0,119 ; 1,19 ; 11,9$ g/L; kibővített szekvencia) különböző koncentrációjú kettős keverékeinek mérési eredményeire alapoztam. A nyers adatokat korrekciónak vetettem alá. Az eredményeket diszkriminancia elemzéssel vizsgáltam és becsléseime is ugyan ezzel a módszerrel készítettem. 


\section{Eredmények és Következtetések}

\subsection{Alapízek vizsgálata egykomponensü rendszerben}

Az íz interakciók vizsgálatához először is tisztában kell lennünk az egykomponensü oldatok adta jelekkel, íz-hatásokkal ezért ezt egyfajta nulladik fejezetként mutatom be. Méréseket végeztem a kiválasztott modell anyagok egykomponensű oldataival a 2 . táblázatban szereplő koncentrációkat alkalmazva.

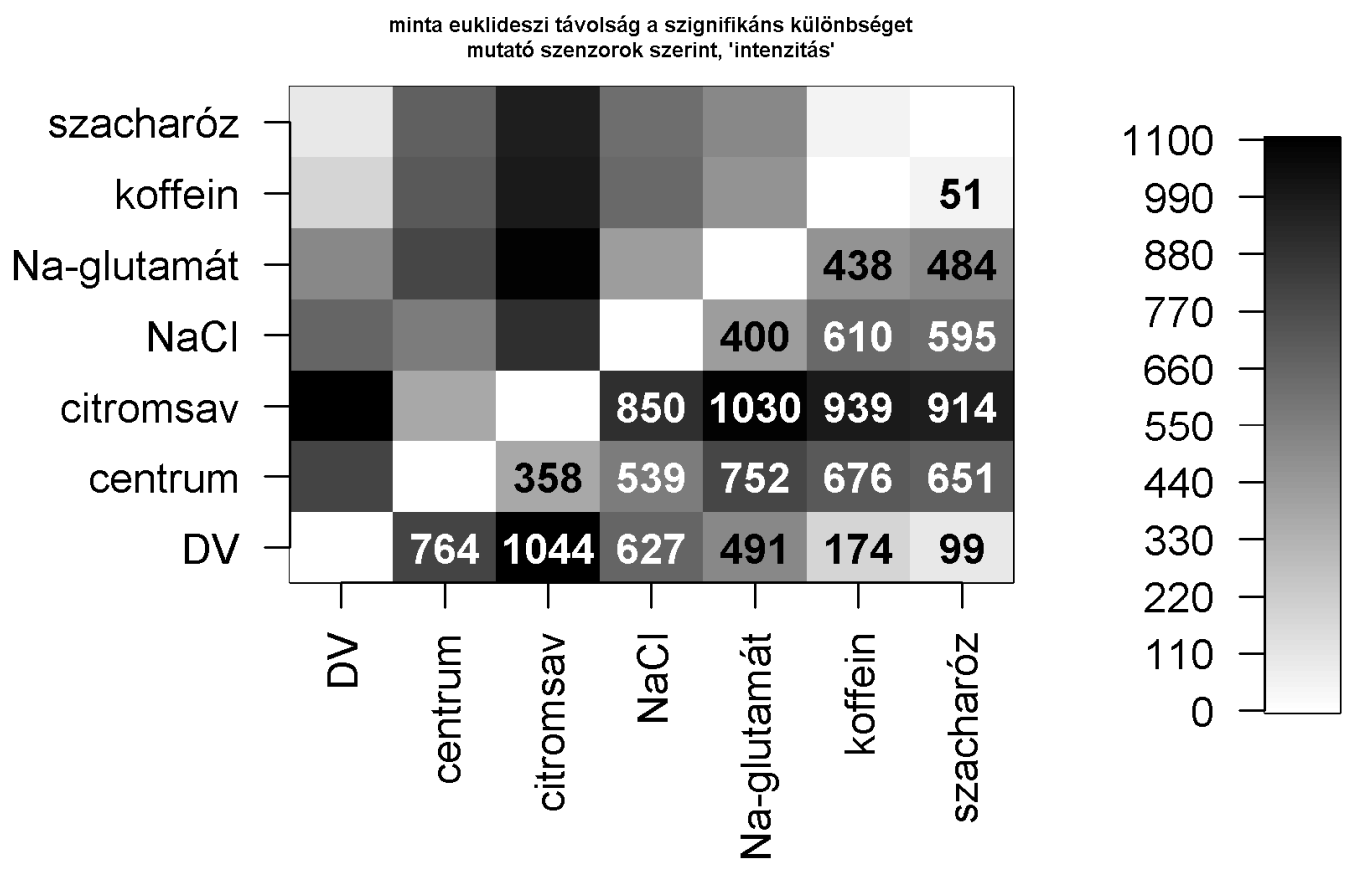

7. ábra Az egykomponensű modell oldatok páronkénti t-próbája és átlagos euklideszi távolságuk a szignifikáns különbséget adó szenzorok által kifeszített térben.

Az 7. ábra az egykomponensü modell oldatok összehasonlítását mutatja be. Két minta szignifikánsan különbözik, ha legalább egy szenzor szerint kimutatható szignifikáns különbség (Welch-próba, $\mathrm{p}<0,01$ ). A különbözés mértékét a mintapontok közötti átlagos euklideszi távolsággal jellemeztem, melyet a szignifikáns különbségért felelős szenzorok által kifeszített térben határoztam meg. Az ábrán megfigyelhetjük, hogy a DV-től minden minta szignifikánsan különbözik, bár a koffein és szacharóz minták csak kis mértékben. Érdekes módon a koffein és a szacharóz nem csak a DV-hez, de egymáshoz is hasonlít a szenzorjelek szerint. Megfigyelhetünk hasonlóságot a centrum és citromsav minták között is, ami arra utal, hogy az öt itt vizsgált komponenst tartalmazó keverék jel-válaszát az elektronikus nyelv szempontjából a citromsav határozza meg leginkább. Ezek után a legjobban a $\mathrm{NaCl}$ és $\mathrm{Na}-$ glutamát minták hasonlítanak. 
A legmarkánsabb különbséget a citromsav minta mutatta a DV és a Na-glutamát mintákhoz képest. Az elemzést standardizált szenzorjelekre elvégezve nagyon hasonló eredményt kapunk.

Az egykomponensü minták egymáshoz képesti elhelyezkedését jól szemléltethetjük diszkriminancia elemzéssel (8. ábra), ahol az egyes elektronikus nyelv szenzorok egymáshoz viszonyított súlyát is megfigyelhetjük a kapott modellben (szenzor nevekkel ellátott nyilak). A minták fökomponens elemzése nagyon hasonló képet mutat, azonban a mintán belüli szórások jobban megjelennek, ami nehezebbé teszi az értelmezést, ezért itt nem mutatom be.
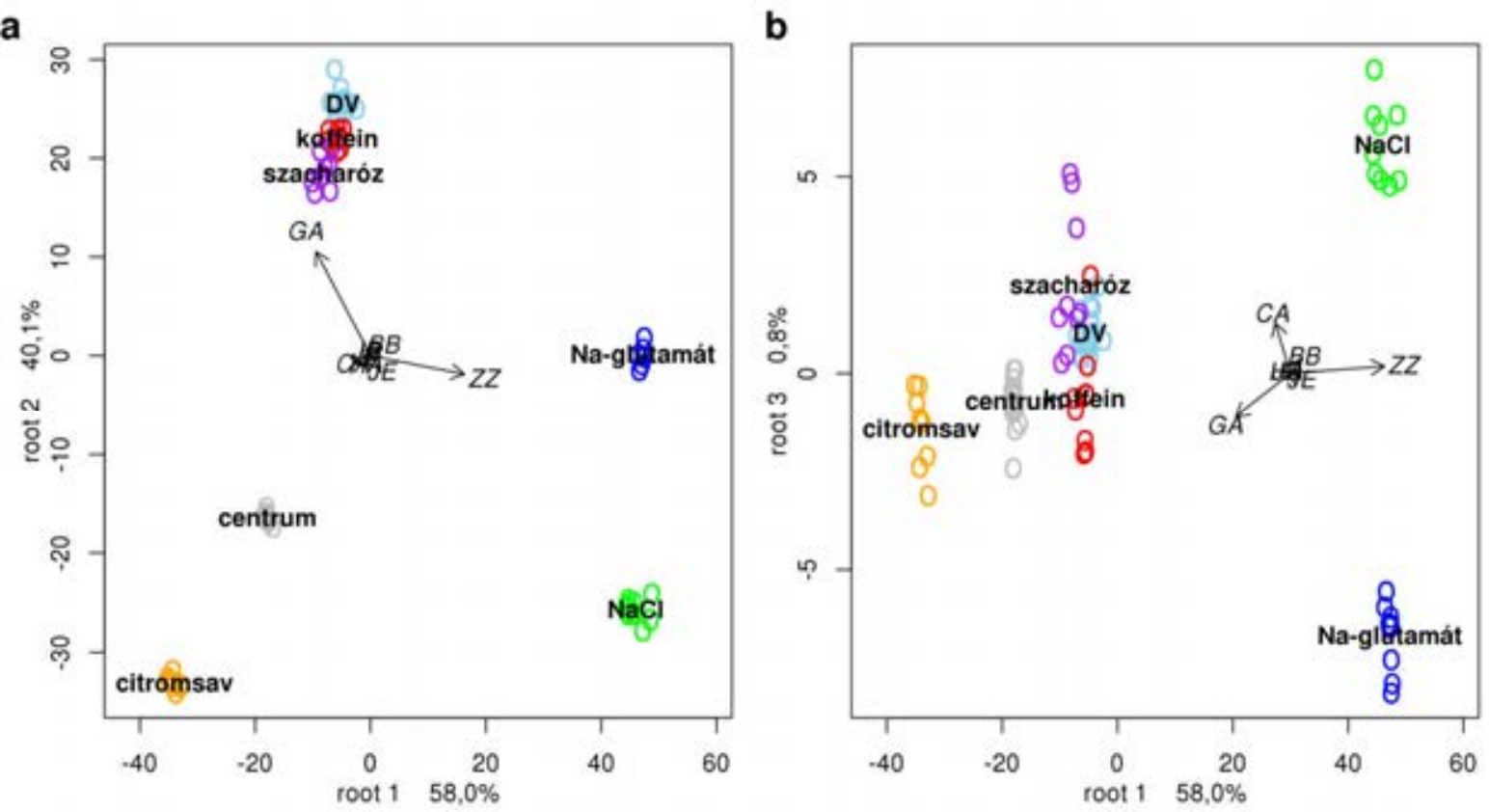

8. ábra Az egykomponensủ modell oldatok diszkriminancia elemzésének ábrái, a) root1 és root 2 szerint valamint $b$ ) root 1 és root 3 szerint. Az ábrákon bemutatott variancia a teljes (csoportok közti) variancia 99\%-a. A nyilak hossza az elektronikus nyelv szenzorok súlyát, irányuk pedig az eredeti szenzorjelekkel való korrelációját reprezentálják a diszkriminancia modellben.

Az ábrán rögtön szembe tünik, hogy a szacharóz és koffein minták alig különböznek a DV mintától, bár tudjuk, hogy ez a különbség szignifikáns. Ez a koffein és a szacharóz mérsékelt hatását mutatja az elektronikus nyelv szenzorokra a többi lemért oldat hatásához képest. A citromsav és centrum minta hasonlósága itt is megfigyelhető.

Az első diszkrimináns változó (a, root 1), melyben a ZZ és GA szenzorok szerepelnek nagy súllyal $(49 \% ; 28 \%)$, a citromsavas mintát különböztették meg a $\mathrm{NaCl}$ és Na-glutamát mintáktól azaz ezek képviselik a két szélső értéket. Érdekes, hogy a $\mathrm{NaCl}$ és Na-glutamát minták a root 1 szerint nem különülnek el. A második diszkrimináns változót (a, root 2) a GA szenzor dominálja (64\%). Ebben az irányban a DV és a citromsav, valamint $\mathrm{NaCl}$ minták képviselik a szélső értékeket, így akár egy fajta általános minta intenzitásnak is elfogadhatjuk. 
Ebben az irányban különülnek el a $\mathrm{NaCl}$ és Na-glutamát minták is. A harmadik diszkrimináns változó szerint (b, root 3), melyben a CA és GA szenzorok súlya meghatározó (41\%; 35\%) szintén a $\mathrm{NaCl}$ és Na-glutamát minták elválasztása történik. (Megjegyezzük, hogy a diszkrimináns modell koefficiensek összehasonlításának igazán csak egy-egy diszkrimináns változón belül van értelme és az adott diszkrimináns változóhoz tartozó variancia hányadot is figyelembe véve vonhattam le következtetést a teljes modellben való súlyokat illetően).

A mérés és egyben a felállított modell egy erős validációja az, ha egy teljesen független mérés eredményeit vetítem a korábban létrehozott modellbe. Ennek eredményeit mutatja a 9. ábra és a 10. ábra.

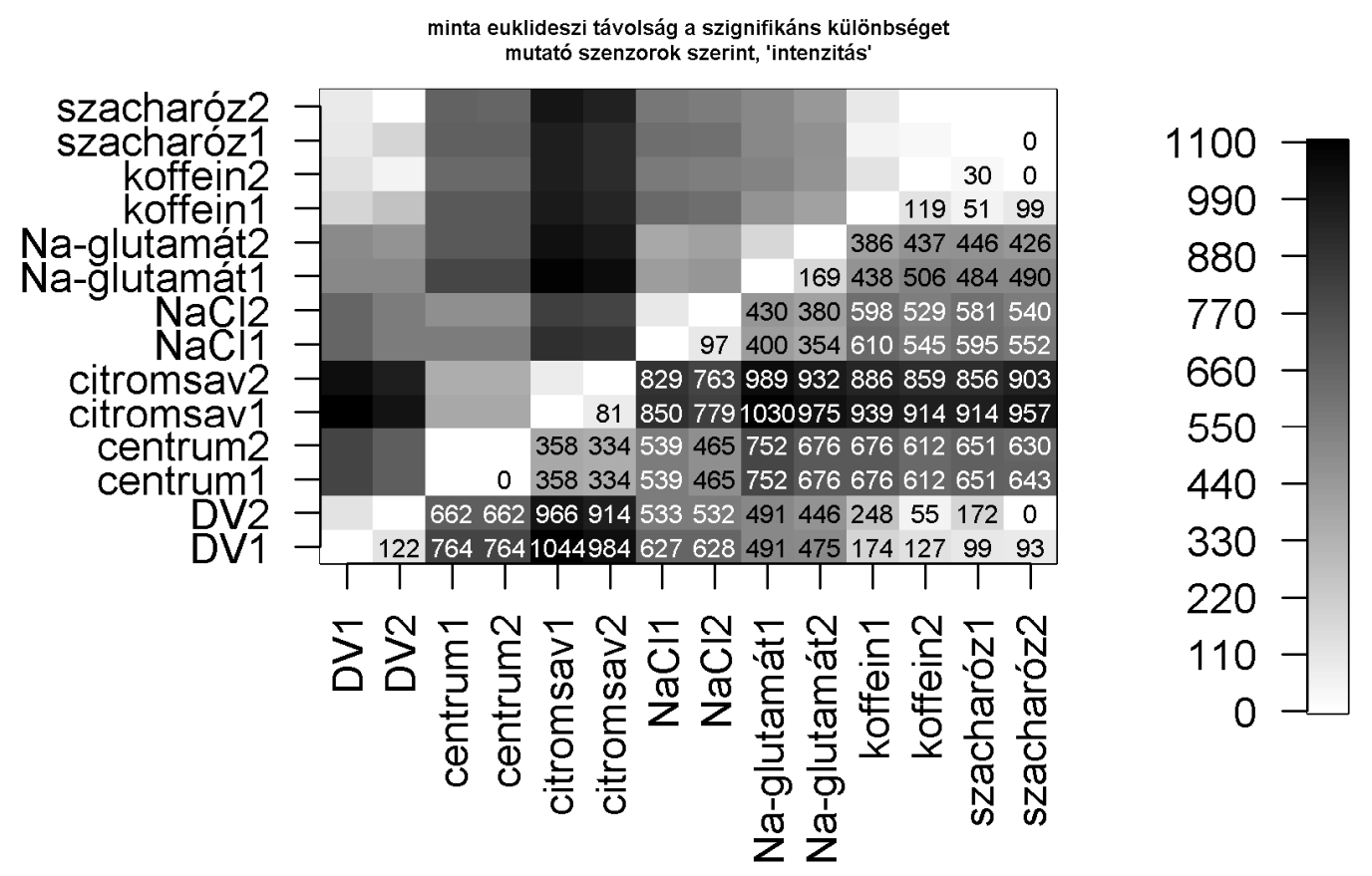

9. ábra Az egykomponensű modell oldatok (1) és validációs oldataik (2) páronkénti tpróbája és átlagos euklideszi távolságuk a szignifikáns különbséget adó szenzorok által kifeszített térben.

A 9. ábra bemutatja, hogy a validációs oldatok (2-sel jelölve) szignifikánsan különböznek a nekik megfelelő első mérési alkalommal használt oldatoktól (az átló alatt világosszürke szegmensek, bennünk az euklideszi távolsággal), melynek oka a mérések közötti drift. Ha megnézzük a diszkriminancia elemzés csoportba sorolási táblázatát (3. táblázat), ahol az eredeti minta csoportokba (kalibráció) próbáljuk besorolni az eredeti és a validációs adatokat, akkor azt látjuk, hogy az első mérési alkalom mintái tökéletesen kerültek besorolásra. A validációs adatok közül a szacharóz mérésekböl egy ismétlés, a koffein mérési eredmények közül pedig mind a 9 ismétlés rossz helyre került. Külön érdekesség, hogy a diszkriminancia modell a koffeint éppen a szacharóz csoportba sorolta. A helytelenül besorolt minták kis jel különbséget ( 100 intenzitás érték) eredményeztek a desztillált vízhez képest és így 
egymáshoz képest is. Két eltérő időben készült mérés esetében a korrekció ellenére is ezek a különbségek elegendően kicsik ahhoz, hogy helyes csoportba sorolást meghiúsítsa.

3. táblázat A diszkriminancia modell kalibráláshoz használt egykomponensű modell oldatok (1-es jelü minták) és validációs oldataik (2-es jelü minták) modell szerinti csoportba sorolása.

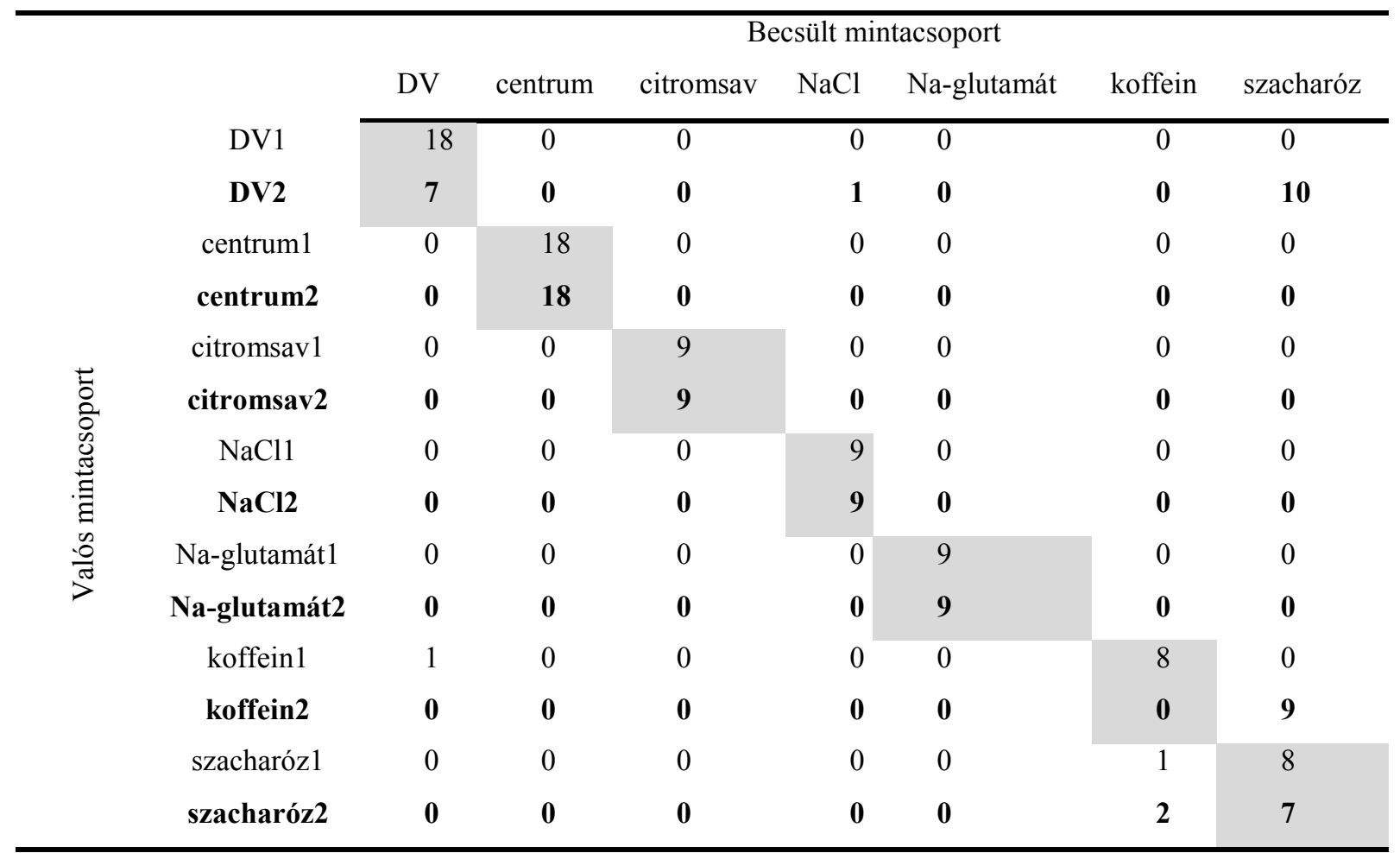

A 10. ábra az első mérési alkalommal mért egykomponensü oldatok és a nekik megfelelő validációs oldatok diszkriminancia elemzés ábráját mutatja. Az ábrán látható, amit az euklideszi távolságok alapján várhattam, azaz a modellben a DV-től eddig is jól elkülöníthető minták (citromsav, $\mathrm{NaCl}$, Na-glutamát) viszonylag jól ismételték magukat és adatpontjaik hasonló helyre estek mind a két mérésben. A koffein és a szacharóz mintáknál ez az ismételhetőség nem ilyen egyértelmű. Meg kell említeni, hogy a DV minták pozíciójában is megfigyelhető az eltolódás, mivel ezek sem ismételték tökéletesen a korábbi mérést, azaz nem estek tökéletesen egy helyre. Ebböl azt az általános következtetést vonhattam le, hogy az elektronikus nyelv jeleire csak gyengén ható anyagok (szacharóz, koffein és tulajdonképpen a desztillált víz is) rosszul ismételhető eredményeket produkálnak. Ennek több lehetséges oka is van: egyrészt a kisebb jelintenzitást produkáló minták egyben nagyobb szórással is mérhetőek és ez esetenként látszólag 'összemossa' a jeleiket. Másrészt a jel korrekció ellenére tökéletes reprodukálhatóságot elérni a nagyobb szórással mérhető minták esetében igen nehéz [Holmin és mtsai. 2001, Kovács 2012]. Emiatt a későbbiekben következtetéseimet főleg olyan mérési eredményekre alapozom, melyekben az egyszerre 
vizsgált minták egy mérésben egyszerre voltak jelen, így elkerülve a mérések közötti drift okozta hibát.
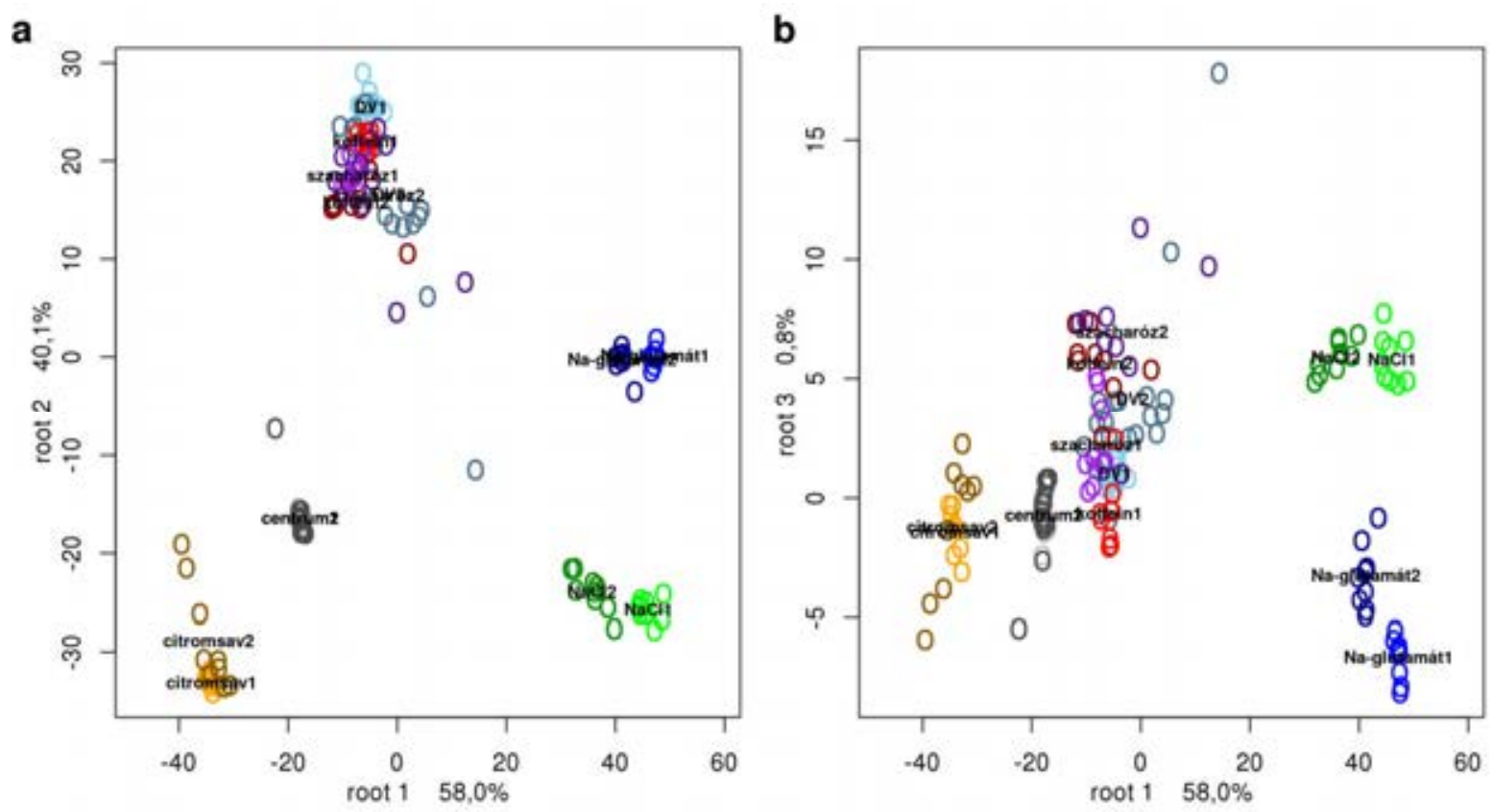

10. ábra Az egykomponensủ modell oldatok és validációs oldataik diszkriminancia elemzésének ábrái. a) root 1 és root 2 szerint; b) root1 és root3 szerint.

\subsection{A citromsav és a NaCl kölcsönhatása}

A 8. ábrán láthattuk, hogy a legtöbb varianciát tartalmazó első diszkrimináns változó szerint a citromsav és a $\mathrm{NaCl}$ különbözik a leginkább egymástól, ráadásul a DV minta e kettő között helyezkedik el, azt mutatva, hogy a semleges ízű DV-hez képest a citromsav az egyik, a $\mathrm{NaCl}$ a másik irányba tolja a szenzorjeleket, azaz az elektronikus nyelv szempontjából ellentétes hatásúak. A citromsav és a $\mathrm{NaCl}$ interakcióit modell oldatokon mutatom be, melyben a két anyag egyszerre és külön többféle koncentrációban is jelen volt, egyes esetekben más vegyületekkel együtt. Egy általános kép kialakításához először vizsgáljuk meg az alkalmazott modell oldatok (mind az 5 féle) kettős kombinációit bemutató diszkriminancia elemzését (11. ábra) még hozzá először csak a kombinált oldatok adatait elemezve (a, b), majd a korábban már felépített és bemutatott egykomponensű oldatokra épített diszkriminancia modellbe (8. ábra) vetítve (c, d). Ez utóbbi elemzés segít az alapíz kombinációkat elhelyezni a tiszta minta oldatok terében (mint egyfajta alapíz térben). A diszkriminancia modell építése elött az adatokon korrekciót hajtottam végre (módszerek 5.3.1), hogy az eltérő mérési alkalom okozta hibákat minimalizáljam. 
a

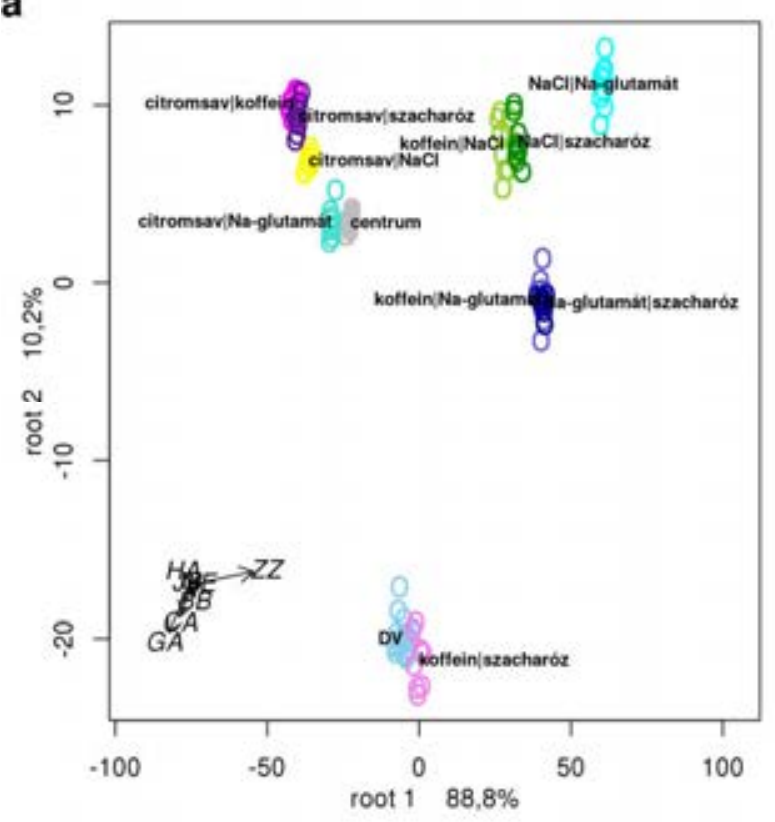

c

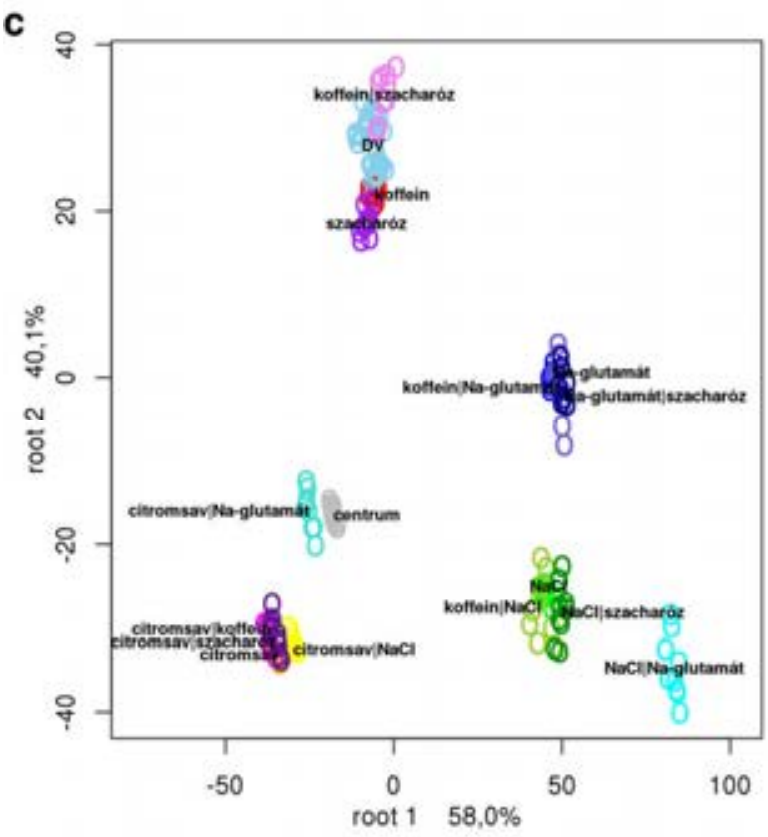

b

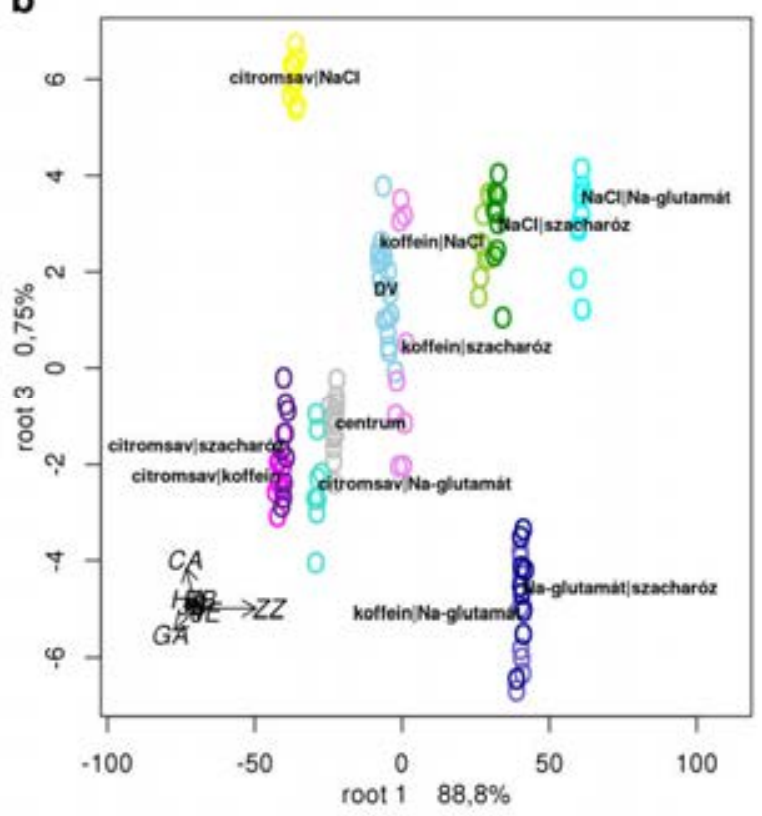

d

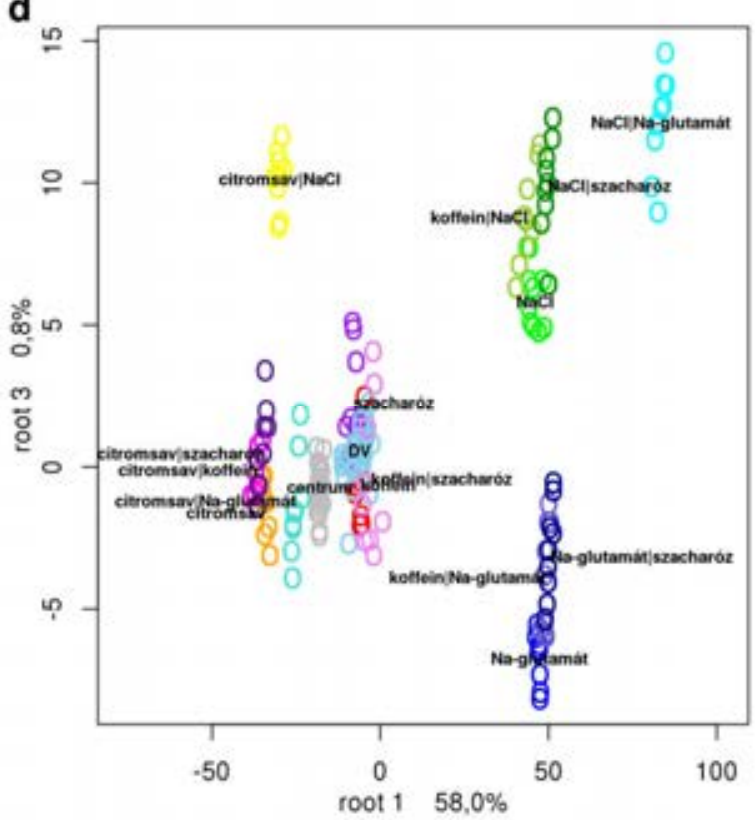

11. ábra Kétkomponensü oldatok diszkriminancia elemzése (a és b) és projekciója az egykomponensü oldatok által meghatározott diszkriminancia modellbe (c és d).

A minták egymáshoz viszonyított elhelyezkedése nagyon hasonló mind a két típusú elemzés esetében. Ennek az a kézenfekvő magyarázata, hogy a kétkomponensű oldatoknál ugyanazok a fö hatások érvényesültek a szenzorokra, mint az egykomponensü minták esetében, annak ellenére is, hogy a minták itt keverékben voltak. Ez úgy alakulhatott ki, hogy a keverékek egyik tagja meghatározóvá válik és gyakorlatilag egykomponensű mintaként viselkedik. Természetesen nem szükséges minden kombinációnak így viselkednie, de a diszkrimináns teret meghatározó mintáknak (azok, melyek az ábra szélén helyezkednek el) mindenképpen. Ehhez hasonlót lehet megfigyelni Pein és mtsai. [2015] munkájában ahol több 
elektronikus nyelv típusnál is a citrát-iont tartalmazó oldatok jelentősen eltértek a citrát-iont nem tartalmazó oldatoktól és a vizsgált minták kettős megoszlását lehet megfigyelni több vizsgált müszer esetében is.

Ha megvizsgáljuk az ábrát, látható, hogy gyakorlatilag a DV-citromsav-NaCl háromszög feszíti ki a diszkrimináns teret az első és második diszkrimináns változó szerint $(\mathbf{a}, \mathbf{c})$ és a citromsav-NaCl-Na-glutamát az első és harmadik diszkrimináns változó esetében (b, d) szinte függetlenül az elemzés módszerétől. (Ugyanezt az elrendezést láthattuk az egykomponensü minták diszkriminancia elemzésénél, 8. ábra.) Míg a citromsav, $\mathrm{NaCl}$ és Na-glutamát keverékek pozíciója megváltozott a tiszta oldatokéhoz képest (van hatás), addig koffein vagy szacharóz hozzáadása az előbb említett komponensekhez csak kis mértékben módosítja a szenzorjeleket és ezért csak kis különbségek látszanak (melléklet 1. ábra).

A 11. ábrán azt is megfigyelhetjük, hogy a citromsav $\mid \mathrm{NaCl}$ és a citromsav|Na-glutamát kombinációk a tiszta citromsav minta közelében helyezkednek el, mely arra utal, hogy a citromsav igen erőteljesen képes meghatározni egy minta karakterét az elektronikus nyelv szempontjából. Azonban az eltérés az első és a második diszkrimináns változó szerint (a, c) nem a tiszta $\mathrm{NaCl}$ vagy Na-glutamát felé történik, hanem a DV minta irányába, ami arra utal, hogy a $\mathrm{NaCl}$ és a Na-glutamát a citromsav jelét csökkenti.

Mivel a lehetséges kölcsönhatások az egyes elektronikus nyelv szenzorokon eltérő módon jelenhetnek meg ezért az elemzést érdemes szenzoronként is elvégezni. Munkámban itt csak 3 szenzort emelek ki, melyeken keresztül az egyes hatások jól demonstrálhatóak, de a melléklet 2. ábrája az összes szenzor megegyező elemzését bemutatja.

A 12. ábra alapján az alábbi megfigyeléseket tehetjük:

1. A citromsavat tartalmazó minták a $Z Z$ szenzor szerint a DV-nél kisebb, míg a $\mathrm{NaCl}$ és Na-glutamát tartalmú minták a DV-nél nagyobb jelet szolgáltatnak. Itt szeretném megjegyezni, hogy a szenzorjel intenzitásnak abszolút értékben nincs jelentősége ( $\mathrm{az} \pm 10^{4}$ között bármekkora lehet), azonban a minták (akár ugyanazon vegyület eltérő koncentrációi) egymáshoz viszonyított előjeles jel különbsége már fontos információt hordoz.

2. A további komponensek ( $\mathrm{NaCl}, \mathrm{Na}$-glutamát) szenzoronként eltérő mértékben módosítják a citromsav jelét, minden esetben a desztillált víz irányába. Ezek a tendenciák azt mutatják, hogy bár a citromsav dominánsan meghatározza a jelszintet szinte az összes szenzornál, a további komponensek módosítják a mért jelet és minden esetben fedő jellegűen, azaz a desztillált vízhez közelítve a megfigyelt jelszintet. 


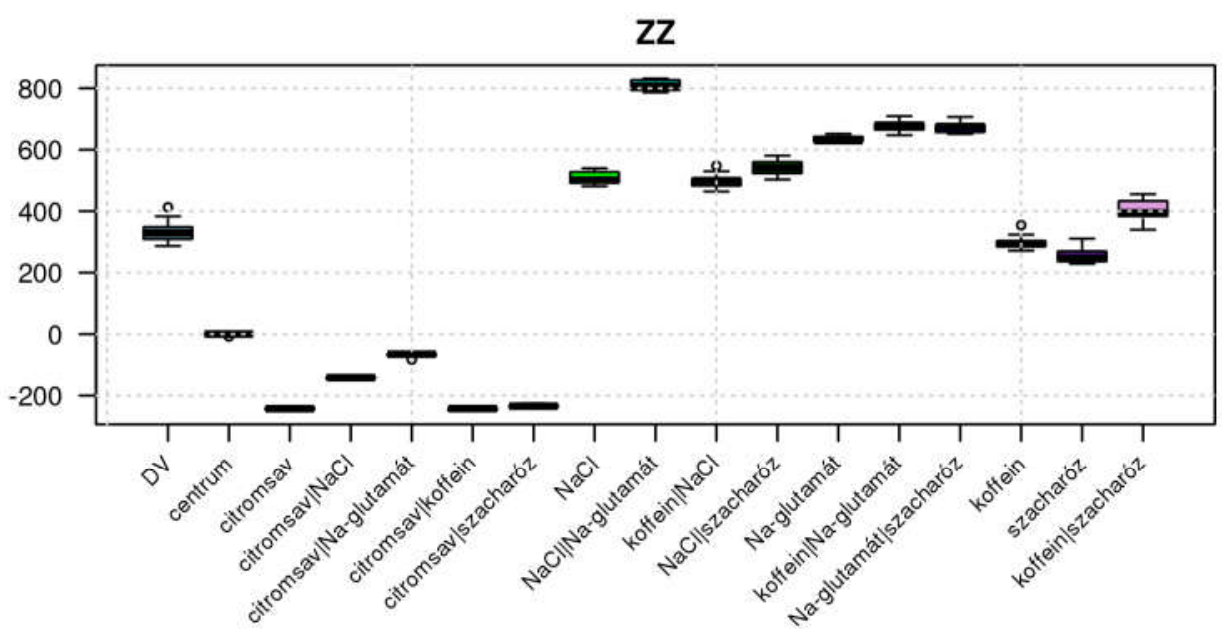

CA

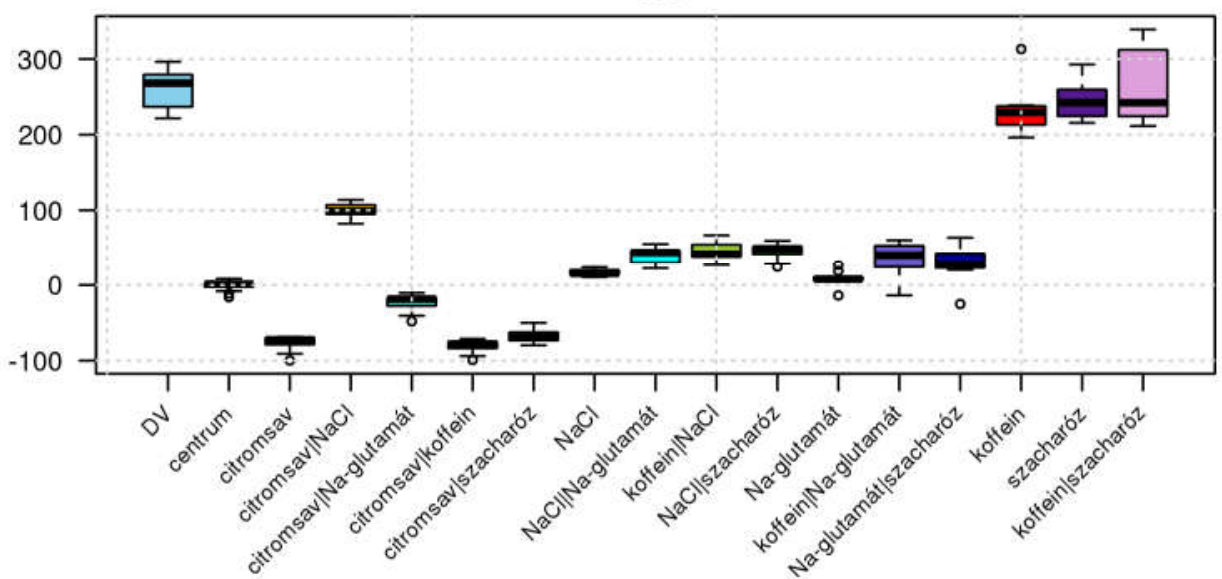

GA

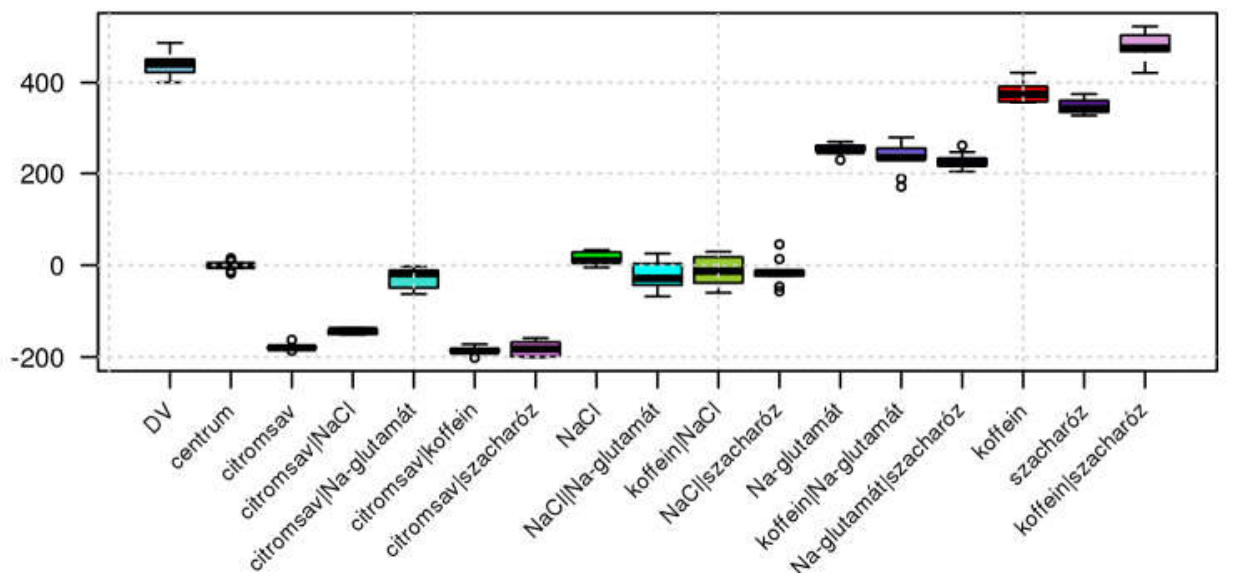

12. ábra Egy és kétkomponensű modell oldatok kiválasztott szenzorainak boxplot ábrája.

3. GA esetében a citromsav|Na-glutamát, koffein| $\mathrm{NaCl}, \mathrm{NaCl} \mid \mathrm{Na}$-glutamát és $\mathrm{NaCl} \mid$ szacharóz kombinációk tünnek egyformának (különbségük nem szignifikáns). Ez utóbbi eredmény arra utal, hogy a GA szenzort egy a kombinációban találhat komponens (jellemzően a $\mathrm{NaCl}$ ) telíti és a további nem savas komponensek nem módosítják a szenzorjelet jelentősen. 
A kölcsönhatások jobb megértéséhez a citromsav $\mid \mathrm{NaCl}$ kombinációt több koncentrációban is megvizsgáltam.
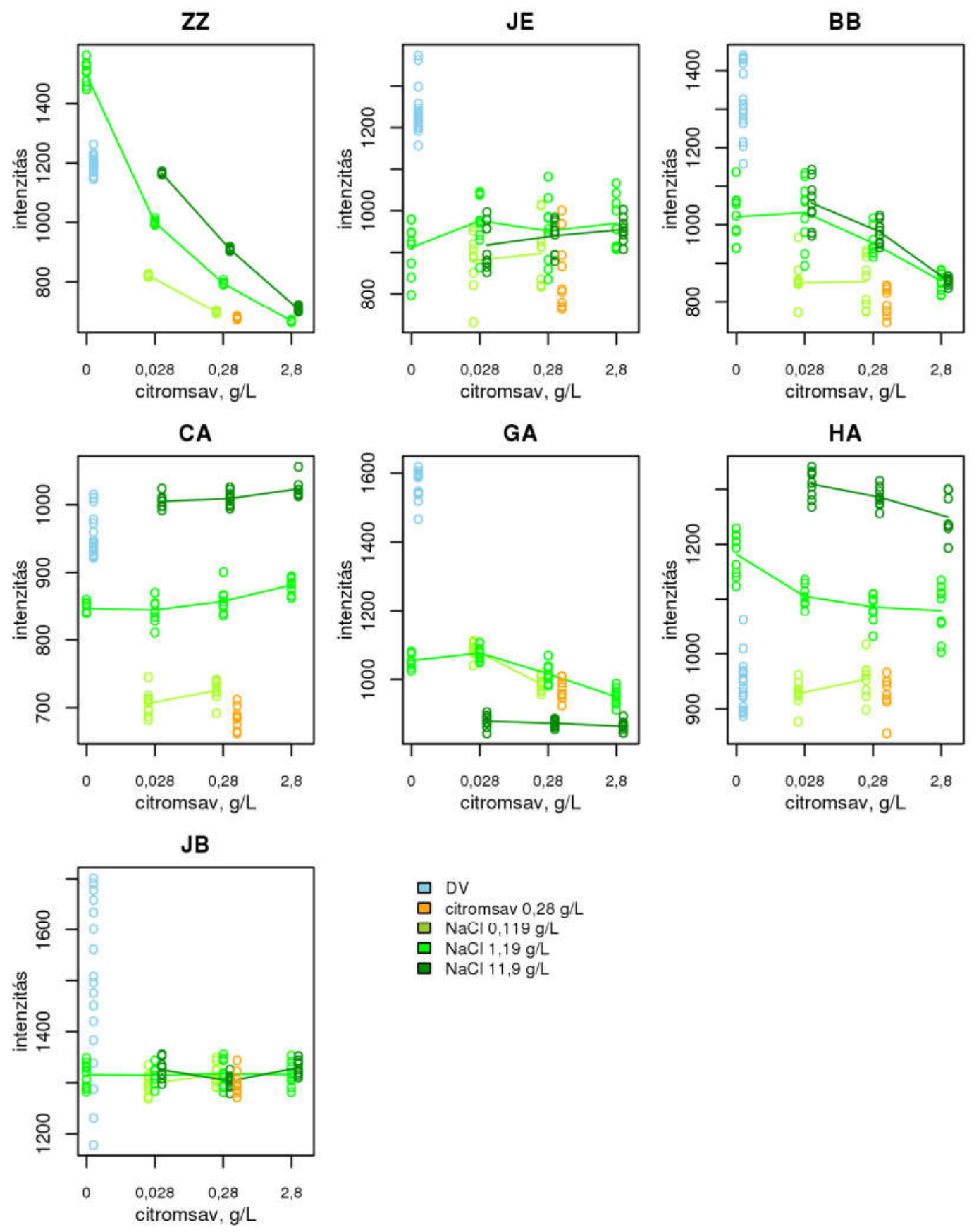

13. ábra Citromsav és $\mathrm{NaCl}$ különböző koncentrációjú keverékeinek elektronikus nyelv szenzorjelei paraméteres görbéken, növekvő citromsav tartalom szerint. Az eltérő színek az eltérő $\mathrm{NaCl}$ koncentrációt jelölik.

A 13. ábra citromsav és $\mathrm{NaCl}$ különböző koncentrációjú keverékeit mutatja be. A korábbiakban a kétkomponensü modell oldatoknál használt koncentrációkat, valamint azoknál tízszer hígabb és töményebb oldatokat vizsgáltam. Az ábrán a következőket tudjuk megfigyelni. 
1. A ZZ szenzor szerint a növekvő citromsav koncentráció csökkenő szenzorjeleket okoz (megegyezően a korábban megfigyeltekkel), azonban NaCl-ot adva a keverékhez a tapasztalható jelszint közelít a DV-hez olyannyira, hogy a $\mathbf{0 , 0 2 8}$ g/L citromsavat és 11,9 g/L NaCl-ot tartalmazó kombináció gyakorlatilag desztillált víznek tünik a $\mathbf{Z Z}$ szenzor szerint. Az is látható, hogy a növekvő citromsav mennyiséget egyre kevésbé módosítja a $\mathrm{NaCl}$. A citromsav már a 0,28 $\mathrm{g} / \mathrm{L}$ koncentrációban is telítésbe vitte a szenzort, hisz az ekkora vagy nagyobb citromsav koncentrációt tartalmazó minták körülbelül egy jelszinten vannak és a ZZ szenzor szerint egyformák.

2. A JE és JB szenzorok nem különböztették meg a mintákat.

3. A BB szenzor esetében minél több a citromsav az oldatban annál kisebbek az eltérő NaCl-ot tartalmazó minták között a különbségek csak úgy, mint a ZZ szenzor esetében csupán kisebb minták közötti abszolút különbséggel.

4. A CA szenzor esetében azt látjuk, hogy bár a tiszta citromsav minta jól megkülönböztethető a DV mintától (t-próba, $\mathrm{p}<2,2 * 10^{-16}$ ), a NaCl-ot is tartalmazó minták jelszintjét gyakorlatilag a $\mathrm{NaCl}$ tartalom határozza meg (holott az érzékelési küszöb erre a szenzorra citromsav esetén $10^{-7} \mathrm{M}$ [AlphaM.O.S. 2002a]). A kisebb $\mathrm{NaCl}$ koncentrációk a desztillált víz jelénél kisebb, míg a tömény $\mathrm{NaCl}$ ot tartalmazó minták annál nagyobb szenzorjelet mutattak. Ez azt mutatja, hogy ennél a szenzornál létezik olyan citromsav| $\mathrm{NaCl}$ kombináció, mely desztillált víznek tünik csakúgy, mint a ZZ szenzor esetében.

5. A HA szenzor esetében szintén a $\mathrm{NaCl}$ tartalom határozza meg a szenzorjel intenzitását. Érdekes még, hogy a kevés NaCl-ot tartalmazó minták gyakorlatilag egybe esnek a DV mintával $(\mathrm{NaCl} 0,119 \mathrm{~g} / \mathrm{L}$, t-próba, $\mathrm{p}=0,30$ és $\mathrm{p}=0,44)$. Ez az eredmény abból a szempontból érdekes, hogy a müszer gyártója szerint a HA szenzor érzékenysége messze meghaladja a használt citromsav (küszöb: $10^{-6} \mathrm{M}$ ) és $\mathrm{NaCl}\left(10^{-4} \mathrm{M}\right)$ koncentrációkat, itt mégsem láttam különbséget a keverékekben.

Az előbb szenzoronként bemutatatott mérés eredményeit, alávetettem diszkriminancia elemzésnek is így megvizsgálhattam, hogy az eddig megfigyelt hatások hogyan jelennek meg egy általánosan használt többváltozós elemzésben. Az ábra átláthatóságának érdekében a keverékekben a citromsav koncentrációkat A,B,C-vel $(0,028 \mathrm{~g} / \mathrm{L} ; 0,28 \mathrm{~g} / \mathrm{L} ; 2,8 \mathrm{~g} / \mathrm{L})$ a $\mathrm{NaCl}$ töménységét pedig 1,2,3-mal $(0,119 \mathrm{~g} / \mathrm{L} ; 1,19 \mathrm{~g} / \mathrm{L} ; 11,9 \mathrm{~g} / \mathrm{L})$ jelöltem így például a B2 egy olyan mintát jelöl, melyben $0,28 \mathrm{~g} / \mathrm{L}$ citromsav és $1,19 \mathrm{~g} / \mathrm{L} \mathrm{NaCl}$ van. Mivel fontos volt, hogy minden minta egy mérésben egyszerre legyen jelen ezért megnövelt minta elemszámmal dolgoztam, de még így is ki kellett hagynom a C1-es jelű mintát. Mivel a magas citromsav 
tartalom várhatóan elnyomja majd az alacsony koncentrációjú $\mathrm{NaCl}$ hatását úgy gondolom ezzel a kihagyással veszítem a legkevesebb információt.

a

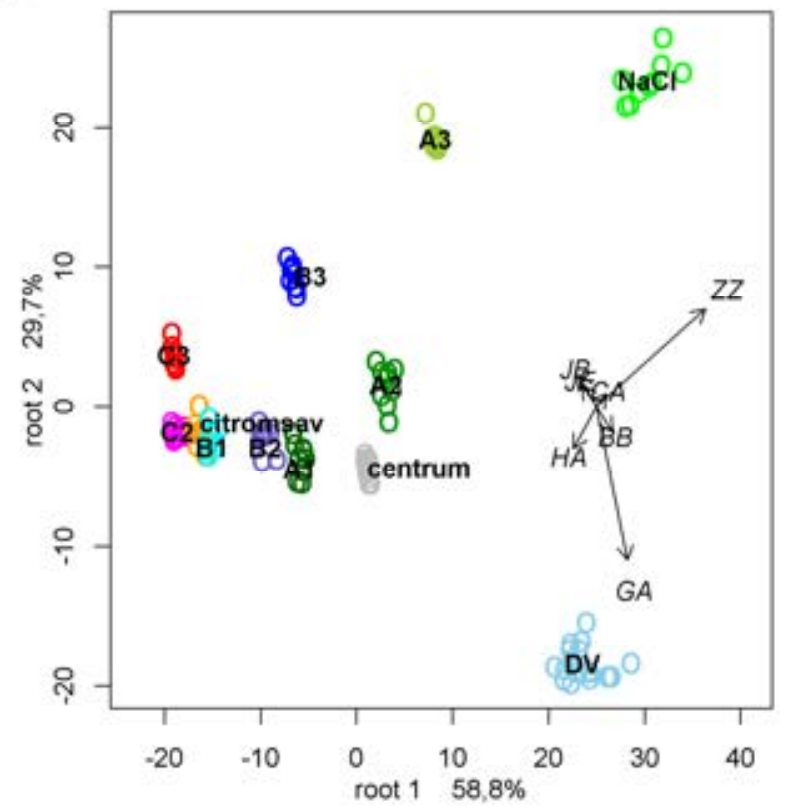

b

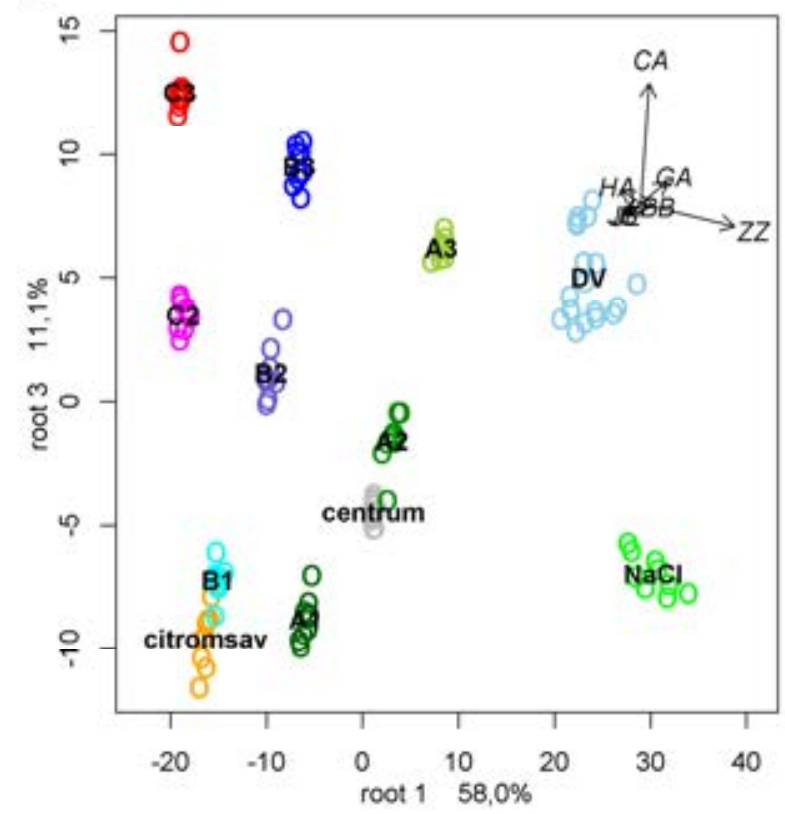

14. ábra Citromsav és $\mathrm{NaCl}$ különböző koncentrációjú keverékeinek elektronikus nyelv mérési eredménye diszkriminancia elemzés után. A citromsav koncentrációkat A,B,C-vel $(0,028 \mathrm{~g} / \mathrm{L} ; 0,28 \mathrm{~g} / \mathrm{L} ; 2,8 \mathrm{~g} / \mathrm{L})$ a NaCl töménységét pedig 1,2,3-mal $(0,119 \mathrm{~g} / \mathrm{L} ; 1,19 \mathrm{~g} / \mathrm{L} ; 11,9$ $\mathrm{g} / \mathrm{L})$ jelöltem így például a B2 egy olyan mintát jelöl, melyben $0,28 \mathrm{~g} / \mathrm{L}$ citromsav és $1,19 \mathrm{~g} / \mathrm{L}$

$\mathrm{NaCl}$ van. A tiszta komponenseket B-vel valamint 2-vel jelöltem. A nyilak hossza az elektronikus nyelv szenzorok súlyát, irányuk pedig az eredeti szenzorjelekkel való korrelációját reprezentálják a diszkriminancia modellben.

Az a panelen az első két diszkrimináns változó szerinti elkülönülést láthatjuk, ahol egy minta minél több citromsavat tartalmazott és minél kevesebb NaCl-ot, annál közelebb esik a tiszta citromsav oldathoz. Természetesen ez várható is, de alátámasztja azt az elképzelést, hogy a citromsav egy igen domináns összetevő. A b panel az első és harmadik root szerint mutatja a minták mérési pontjainak elhelyezkedését. Fontos megjegyezni, hogy a harmadik rootot a CA szenzor erősen meghatározza (határozott függőleges nyíl), amit korábban NaCl-ra érzékenyebbnek találtam. Egy adott citromsav koncentrációt tartalmazó minták egy sorban helyezkednek el, minél magasabb a NaCl tartalom annál jobban távolodva a tiszta citromsavtól, de nem a tiszta $\mathrm{NaCl}$ felé, hanem a DV irányába. Ez természetesen a legkisebb citromsav tartalmú mintákra illik a legjobban. Ennek oka, hogy a CA szenzor a citromsavat csak kis mértékben, de a $\mathrm{NaCl}$-ot nagyon érzékenyen képes mérni és a koncentráció növekedésével a citromsavas jelleget fedi el a $\mathbf{~ N a C l}$.

Mindezeken felül azt figyeltem meg, hogy egy domináns minta jelenléte megváltoztatja a minták közötti különbségeket annak ellenére, hogy a változás 'egységnyi' azaz két minta 
pár között ugyanaz az eltérés (pl.: 10-szeresére nő a NaCl tartalom): A1-2-3 és B1-2-3, C2-3. A kisebb citromsav koncentrációjú mintákban a $\mathrm{NaCl}$ változásnak nagyobb hatása van.

A citromsav és $\mathrm{NaCl}$ ellentétes hatásának további bizonyítására PLS modellt készítettem egy $\mathrm{NaCl}$ hígítási sor segítségével (a koncentrációk logaritmusát használva, $\mathrm{R}^{2}=0,96$; $\mathrm{RMSEP}=0,2665$ logaritmikus $\mathrm{NaCl}$ koncentráció) és ezzel becsültem a citromsav $\mid \mathrm{NaCl}$ kombinációk 'látszólagos' $\mathrm{NaCl}$ tartalmát (15. ábra). Az ábra könnyebb átláthatóságának érdekében, a becsült koncentrációkat az x tengelyen a becsült csoport átlagával vettem, így vízszintesen az átlag olvasható le függőlegesen pedig a terjedelem. Ennek az ábrázolásnak további előnye, hogy a hasonló értékünek becsült minták is külön megfigyelhetőek, nem csúsznak egymásra. A becslés szerint a tiszta citromsavnak(narancs színnel), valamint a magas citromsav tartalmú minták (piros, magenta és cián színnel) látszólagos $\mathbf{N a C l}$ koncentrációja még a DV (égszínkék színnel) becsült NaCl koncentrációjánál is kisebb.

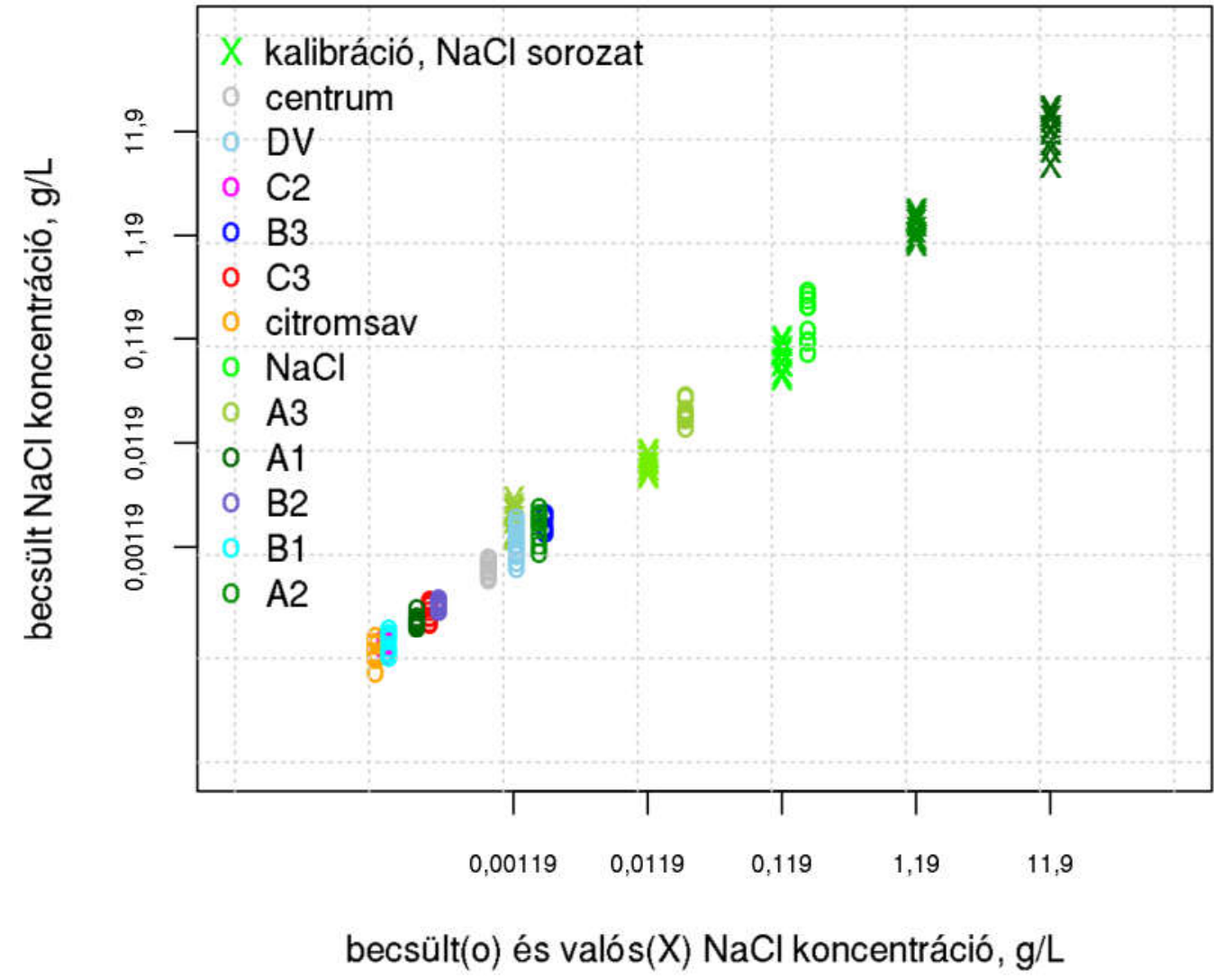

15. ábra $\mathrm{NaCl}$ hígítási sorának szenzorjelei alapján épített PLS modell és az avval becsült citromsav $\mid \mathrm{NaCl}$ kombinációk, centrum, $\mathrm{DV}$, és tiszta $\mathrm{NaCl}$ és citromsav minták látszólagos $\mathrm{NaCl}$ koncentrációja.

A fejezetben bemutatott bizonyítékok mind arra utalnak, hogy bár a citromsav igen dominánsan meghatározza az elektronikus nyelv szenzorjeleit a $\mathrm{NaCl}$ azt képes csökkenteni és a citromsavval ellentétes módon hatni. Kobayashi és mtsai. munkájukban a citromsav és a $\mathrm{NaCl}$ hatását hasonló típusúnak írják le (ellentétben a mi eredményeinkkel), azaz 
kísérleteikben a szenzorjelek azonos irányba változtak a vegyületek vizsgálatakor [Kobayashi és mtsai. 2010]. Az eredmények különbözősége az alkalmazott szenzorok és mérési módszerek különbségében keresendő. Bár az Alpha Astree elektronikus nyelv esetében az érzékelők membrán összetétele nem ismert az bizonyos, hogy az egyes érzékelők esetében nagy különbségek vannak, ami abból látszik, hogy egyes vegyületekre teljesen ellentétes módon (a szenzorjel ellentétes előjellel) változik például a citromsav a ZZ és CA érzékelőknél. Kobayashi és munkatársai eredményeit kizárólag negatívan töltött felületü érzékelők esetére mutatja be.

Egy másik publikáció szerint, melyet szintén az előbb idézett kutató csoporthoz tartozó kutatók adtak közre, bemutatják az egyes alapízeknek megfeleltethető vegyületek (ecetsav, $\mathrm{NaCl}$, Na-glutamát, stb.) koncentráció sorozatának szenzorjeleit [Tahara Y. és mtsai. 2013]. Bár itt minden vegyülethez egy az adott ízt mérni hivatott szenzor jeleit mutatják be látható, hogy az általam közölt eredményekhez nagyon hasonló azaz az ecetsav és a $\mathrm{NaCl}$ szenzorjele ellentétesen változik a koncentráció emelkedésével. A szerzők bemutatják egy érzékelőjük (melyet savanykás-keserü szenzornak neveznek) esetében a kapott szenzorjeleket. A $\mathrm{KCl}$ (sós) hatására nő a szenzorjel, míg a borkősav (savanyú) hatására csökken. Ez a viselkedés figyelhető meg az Astree elektronikus nyelv ZZ szenzorának esetében is. A szerzők állítása szerint a kereskedelmi forgalomban is kapható müszer szenzorjeleit mutatták be

\subsection{A NaCl és a Na-glutamát kölcsönhatása}

A $\mathrm{NaCl}$ és Na-glutamát kölcsönhatásait az előbbi fejezethez hasonló módon vizsgáltam. A kétkomponensủ oldatokat vizsgáló elemzésben (11. ábra) azt már megfigyelhettem, hogy a Na-glutamát is képes a citromsav jelét hatékonyan csökkenteni (az elmozdulás ez esetben nagyobb, mint a $\mathrm{NaCl}$ esetében). Ha a DV mintát tekintjük a kiinduló pontnak, akkor a $\mathrm{NaCl}$, Na-glutamát és keverékük közel azonos irányban térnek el oly módon, hogy az egykomponensű $\mathrm{NaCl}$ és Na-glutamát oldatok a DV és a kombinált oldat között helyezkednek el. Ez utóbbi jelenség a két vegyület kölcsönhatásának additív jellegére utal.

Ugyan ezen mérés boxplot ábrája alapján (12. ábra és a melléklet 2. ábrája) a következő megfigyeléseket tehetjük.

1. A ZZ szenzor szerint a $\mathrm{NaCl}$ és Na-glutamát valamint keverékük azonos irányban tér el a DV mintától még pedig úgy hogy a keverék található a legtávolabb.

2. A BB és CA szenzorok szerint a $\mathrm{NaCl} \mid \mathrm{Na}$-glutamát, koffein| $\mathrm{NaCl}, \mathrm{NaCl}$ |szacharóz, koffein|Na-glutamát és Na-glutamát|szacharóz kombinációk gyakorlatilag 
egyformának látszanak (különbségük nem szignifikáns), mely a szenzorok telítettségére utal.

A két vegyület kölcsönhatásának részletesebb megismerésére különböző koncentrációjú keverékeiket is megvizsgáltam (16. ábra). A mintatartó helyek korlátozott száma, és a kényszer, hogy az összehasonlítandó mintákat lehetőleg egy mérésben, egyszerre vizsgáljam arra kényszerített, hogy egy kombinációt kihagyjak. Ez a legmagasabb koncentrációjú $\mathrm{NaCl}$ és legalacsonyabb Na-glutamát keveréke volt (jele A3 lenne, lsd. lent). Mivel feltehetően a magas $\mathrm{NaCl}$ koncentráció telítésbe viszi a szenzor jeleket, úgy gondolom ezzel a kihagyással veszítem a legkevesebb információt.

Míg a vízszintes tengelyen az eltérő Na-glutamát koncentrációk láthatóak, addig az eltérő színek az eltérő $\mathrm{NaCl}$ koncentrációkat jelölik. A korábbiakban használt koncentrációkat valamint azoknál tízszer hígabb és töményebb oldatokat vizsgáltam. Az alábbi megfigyeléseket tehetjük.

1. A ZZ szenzor esetében minden mintára a DV-nél nagyobb értékeket figyelhettem meg (ellentétben a citromsavas mintákkal). Magasabb koncentrációk magasabb szenzorjelet okoznak, ami additív jelleget mutat.

2. A JE szenzor esetében a DV mintától szignifikánsan (t-próba, $\mathrm{p}<2,2 * 10^{-16}$ ) különböznek a mintáink, de egymástól már nem.

3. BB és JB szenzornál egyáltalán nem lehetett különbségeket megfigyelni ezekre az oldatokra.

4. CA, GA és HA szenzorok esetében minél magasabb a $\mathrm{NaCl}$ koncentráció, annál jobban determinálja a jelszintet és teszi függetlenné a Na-glutamát mennyiségétől (a görbék 'kiegyenesednek' a $\mathrm{NaCl}$ koncentráció növekedésével), ami egy telítődés jellegü folyamatra hívja fel a figyelmet, melyben a $\mathrm{NaCl}$ gátolja a $\mathrm{Na}$ glutamát hatásának megjelenését. Ezt már a 12. ábra egy és kétkomponensü mintáinak diszkriminancia elemzésénél is megfigyelhettem a GA szenzorra.

5. A CA esetében a legtöményebb minta jel intenzitása nem különbözik szignifikánsan a desztillált víztől (t-próba, $\mathrm{p}=0,110)$.

6. A HA szenzor esetében szignifikánsan csak a legtöményebb NaCl-ot tartalmazó minták váltak el a többitől ( $\mathrm{NaCl} 11,9 \mathrm{~g} / \mathrm{L}$, t-próba, $\mathrm{p}=2,21 * 10^{-8}$ és $\left.\mathrm{p}=2,78^{*} 10^{-8}\right)$.

Több szenzorjelei alapján azt lehet megállapítani, hogy a NaCl és Na-glutamát hasonló tendenciák szerint alakítja a mérhető jelet az egyes szenzorokon, de az érzékenységben van különbség a két vegyület között. Ezt alátámasztja, hogy egyes keverékek és tiszta komponensek hasonló jel intenzitást mutatnak és a koncentrációk növelése konzisztensen egy irányba módosítja a szenzorjeleket függetlenül attól, hogy NaCl-ról vagy Na-glutamátról van 
szó. Ezt tudtam megfigyelni az egy és kétkomponensü minták diszkriminancia elemzésének ábráin is ahol a tiszta és kevert $\mathrm{NaCl}$ és Na-glutamát a DV-től többé kevésbé azonos irányba 'mozdította el' a minta csoportok elhelyezkedését (8. ábra és 11. ábra).
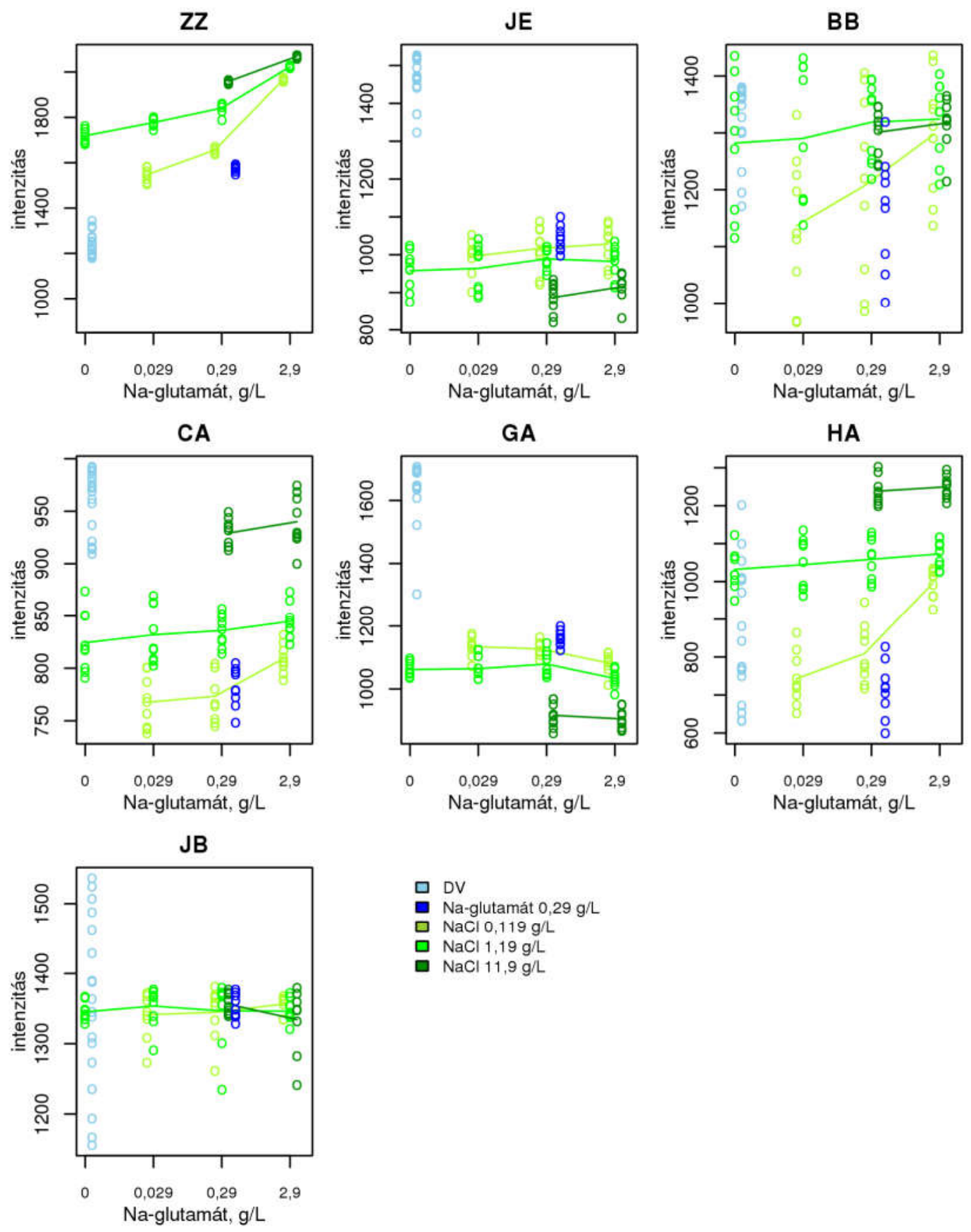

16. ábra $\mathrm{NaCl}$ és Na-glutamát különböző koncentrációjú keverékeinek elektronikus nyelv szenzorjelei paraméteres görbéken növekvő Na-glutamát tartalom szerint. Az eltérő pont színek az eltérő $\mathrm{NaCl}$ koncentrációt jelölik.

Az előbb szenzoronként bemutatatott mérés eredményeit ebben az esetben is alávetettem diszkriminancia elemzésnek is (17. ábra). Az ábra átláthatóságának érdekében a keverékekben a Na-glutamát koncentrációkat A,B,C-vel $(0,029 \mathrm{~g} / \mathrm{L} ; 0,29 \mathrm{~g} / \mathrm{L} ; 2,9 \mathrm{~g} / \mathrm{L})$ a NaCl töménységét pedig 1,2,3-mal $(0,119 \mathrm{~g} / \mathrm{L} ; 1,19 \mathrm{~g} / \mathrm{L} ; 11,9 \mathrm{~g} / \mathrm{L})$ jelöltem így például a B2 egy olyan mintát 
jelöl, melyben 0,29 g/L Na-glutamát és 1,19 g/L NaCl van. Az elemzést elvégeztem a teljes minta együttesre és a centrum minta nélkül is, mivel ez utóbbi a citromsav tartalom miatt markánsan különbözik a többitől és a diszkriminancia modellben nagy súlyt kap, holott jelen esetben a $\mathrm{NaCl}$ és a Na-glutamát okozta hatásokat szeretném megfigyelni.

Ezen az ábrán nem látható az a határozott csoportosulás a tiszta komponensek mentén, mint a citromsav $\mid \mathrm{NaCl}$ kombinációk esetében (14. ábra). Sőt, a mintateret nem is a DV-NaClNa-glutamát tiszta oldatok feszítik ki, hanem a DV, a legtöményebb C3 jelü minta és centrum minta (mint egyetlen citromsavat tartalmazó minta). Gyakorlatilag egy sorozat alakul ki a leghígabb mintától a legtöményebb felé a minták összes oldott anyagának megfelelően és a minták egy vonalban való elhelyezkedése azt mutatja, hogy a $\mathrm{NaCl}$ és a Na-glutamát hatása azonos típusú, összeadódó jellegü csupán intenzitásban van különbség. A centrum minta nélkül elvégzett diszkriminancia elemzésben (17. ábra, b) nagyon hasonló elrendezést figyelhetünk meg, ahol a leghígabbtól a legtöményebb felé sorakoznak a minták.

a
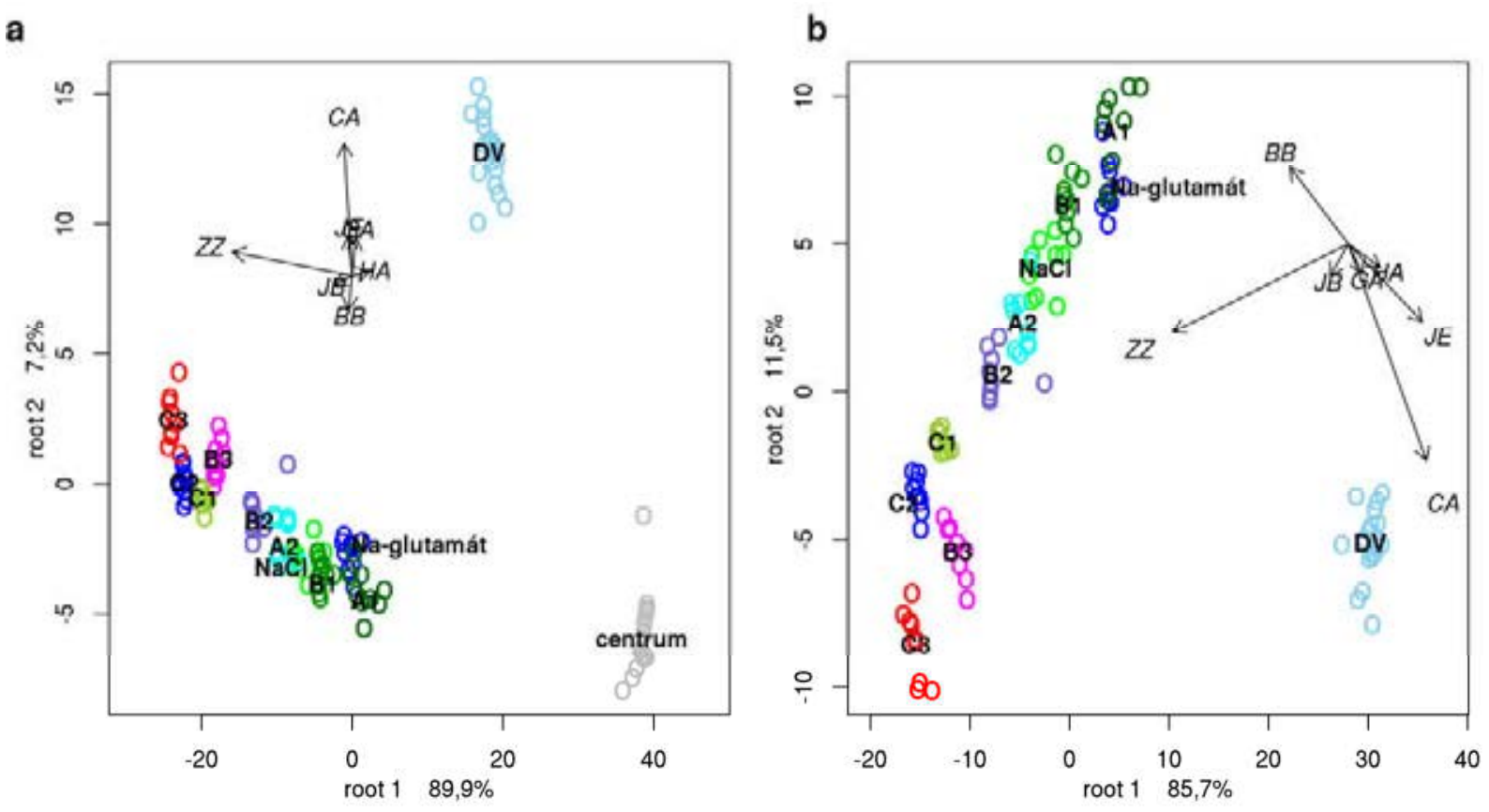

17. ábra $\mathrm{NaCl}$ és Na-glutamát különböző koncentrációjú keverékeinek elektronikus nyelvvel mért szenzorjelei diszkriminancia elemzéssel kiértékelve. Az elemzést a centrum mintát is bevonva (a) és nélküle is elvégeztem (b). A Na-glutamát koncentrációkat A,B,C-vel $(0,029 \mathrm{~g} / \mathrm{L} ; 0,29 \mathrm{~g} / \mathrm{L} ; 2,9 \mathrm{~g} / \mathrm{L})$ a NaCl töménységét pedig 1,2,3-mal $(0,119 \mathrm{~g} / \mathrm{L} ; 1,19 \mathrm{~g} / \mathrm{L} ; 11,9$ $\mathrm{g} / \mathrm{L}$ ) jelöltem így például a B2 egy olyan mintát jelöl, melyben $0,29 \mathrm{~g} / \mathrm{L}$ Na-glutamát és 1,19 $\mathrm{g} / \mathrm{L} \mathrm{NaCl}$ van. A tiszta komponensek a B-vel valamint 2-vel jelölt koncentrációkban vannak.

A nyilak hossza az elektronikus nyelv szenzorok súlyát, irányuk pedig az eredeti szenzorjelekkel való korrelációjukat reprezentálja a diszkriminancia modellben. 
Ahhoz, hogy a hatásokat számszerüsíthessem PLS modellt készítettem, a korábban már felhasznált $\mathrm{NaCl}$ hígítási sor segítségével (a $\mathrm{NaCl}$ koncentrációk logaritmusát használva, $\mathrm{R}^{2}=0,96$; $\mathrm{RMSEP}=0,2665$ logaritmikus $\mathrm{NaCl}$ koncentráció). A két eltérő időpontban készült mérés tökéletes korrekciója nem volt lehetséges, melynek okairól a 6.6 fejezetben számolok be részletesen. Az ábra könnyebb átláthatóságának kedvéért itt is, a becsült koncentrációt az $\mathrm{x}$ tengelyen a becsült csoport átlagával vettem, így vízszintesen az átlag olvasható le függőlegesen pedig a terjedelem.

A becslés alapján látható (18. ábra), hogy a modell a legtöményebb C3-as mintát becsülte a legmagasabb látszólagos $\mathrm{NaCl}$ koncentrációval $(23,18 \mathrm{~g} / \mathrm{L})$ a $\mathrm{DV}$ és a centrum mintákat pedig a legalacsonyabbal (rendre 0,0097 és $0,0024 \mathrm{~g} / \mathrm{L}$ ). A PLS modell ebben az esetben is az egyetlen citromsav tartalmú mintát becsülte a legkisebb $\mathrm{NaCl}$ koncentrációjúnak. A tiszta $\mathrm{NaCl}$ mintát alacsonyabb koncentrációjúnak becsülte, mint amennyi valójában $(0,5826 \mathrm{~g} / \mathrm{L})$ ez a sikertelen korrekciót jelzi.

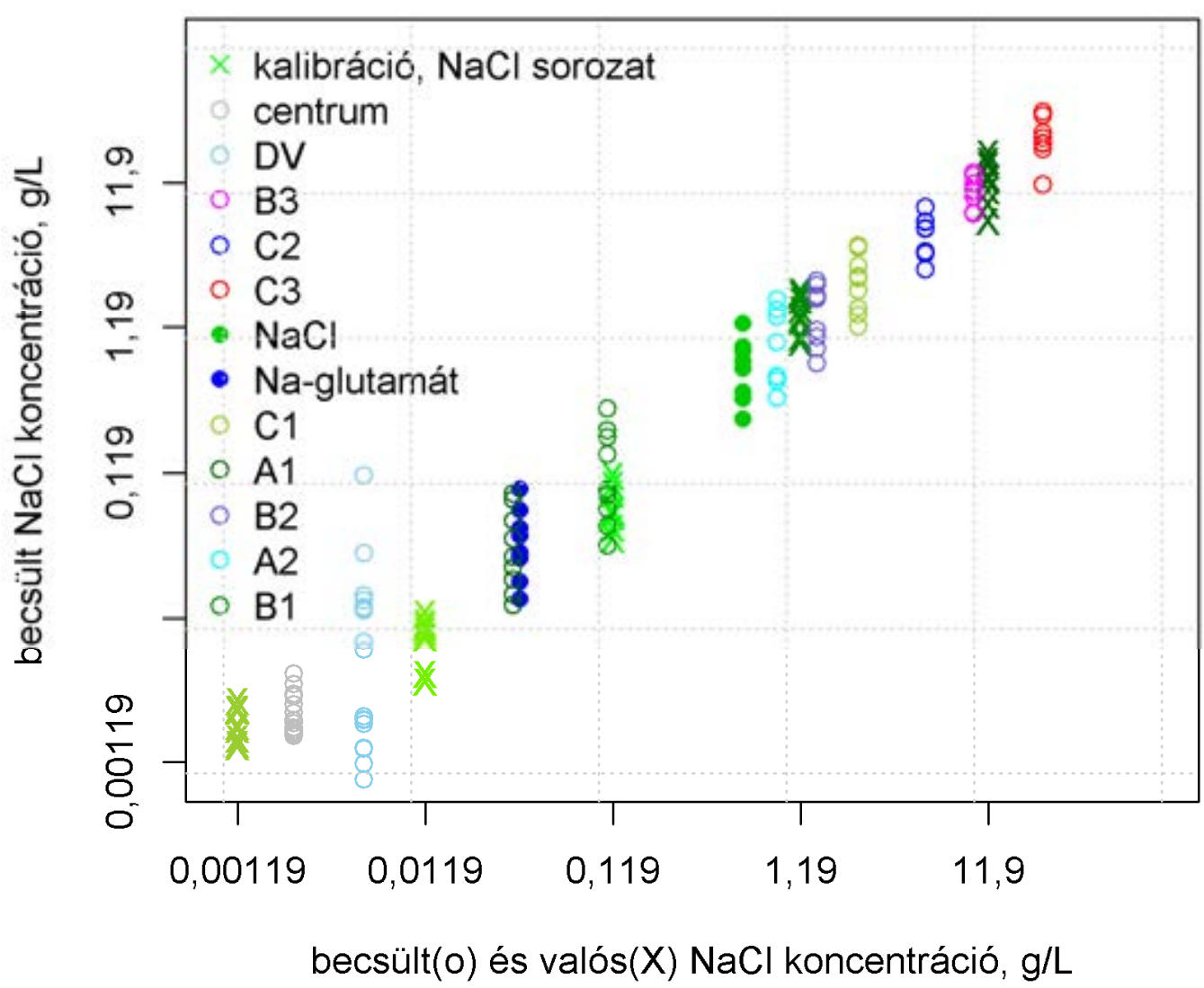

18. ábra $\mathrm{NaCl}$ hígítási sorának szenzorjelei alapján épített PLS modell és az avval becsült $\mathrm{NaCl} \mid \mathrm{Na}$-glutamát kombinációk, centrum, $\mathrm{DV}$, és tiszta $\mathrm{NaCl}$ és Na-glutamát minták látszólagos $\mathrm{NaCl}$ koncentrációja.

$\mathrm{Az}$ 4. táblázat a $\mathrm{NaCl} \mid \mathrm{Na}$-glutamát keverékek becsült $\mathrm{NaCl}$ koncentrációját mutatja be. Bár a becslés számszerü értékei nem pontosak (mivel a tiszta $\mathrm{NaCl}$ oldatot helytelenül 0,5826 
g/L-nek becsülte a modell 1,19 g/L helyett), a becsült $\mathrm{NaCl}$ koncentrációk minden esetben balról jobbra és fentről lefelé nőnek. Ez azt jelenti, hogy mind a $\mathrm{NaCl}$ mind a Na-glutamát oldatbéli koncentrációjának növekedése növelte a becsült $\mathrm{NaCl}$ koncentrációt, tehát hatásuk azonosnak tekinthető.

4. táblázat $\mathrm{NaCl} \mid \mathrm{Na}$-glutamát keverékek becsült $\mathrm{NaCl}$ koncentrációja egy $\mathrm{NaCl}$ hígítási sorra épített PLS modell szerint.

\begin{tabular}{|c|c|c|c|c|c|}
\hline & & \multicolumn{4}{|c|}{ Na-glutamát koncentráció, g/L } \\
\hline & & 0 & 0,029 & 0,29 & 2,9 \\
\hline \multirow{4}{*}{ 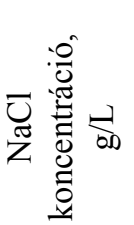 } & 0 & 0,0097 & & 0,0378 & \\
\hline & 0,119 & & 0,0348 & 0,1110 & 2,401 \\
\hline & 1,19 & 0,5826 & 0,8873 & 1,434 & 5,466 \\
\hline & 11,9 & & & 9,928 & 23,18 \\
\hline
\end{tabular}

Egy további bizonyíték a $\mathrm{NaCl}$ és Na-glutamát elektronikus nyelvre kifejtett hatásának hasonlóságára az, hogy hatásuk a citromsavval szemben is hasonló. Ezt a három komponensü modell oldatok eredményeinek az egykomponensü oldatok adataira épített diszkriminancia modellbe vetítve figyelhetjük meg a legkönnyebben (19. ábra). Az ábrán láthatjuk, hogy a citromsav hatását a Na-glutamát és a $\mathrm{NaCl} \mid \mathrm{Na}$-glutamát együttes hozzáadása csökkenti a legjobban, tehát a $\mathrm{NaCl}$ és Na-glutamát citromsavra való hatásukban is igen hasonlóak. Ez természetesen azt is jelenti, hogy a Na-glutamát is fedően hat a citromsavra. A számszerüsített különbségeket a melléklet 3. ábrája mutatja be.

A NaCl-dal és Na-glutamáttal kapcsolatban is szeretném Kobayashi és mtsai. eredményeit felidézni, mivel szerintük a $\mathrm{NaCl}$ és a Na-glutamát ellentétes hatást fejt ki az elektronikus nyelv szenzorokra, mely ellentétes az eredményeimmel [Kobayashi és mtsai. 2010]. Ehhez hasonló eredményre jutott Nagamori és munkatársai hozzátéve, hogy a Na-glutamát képes elfedni a $\mathrm{NaCl}$ ízét az elektronikus nyelv eredményei szerint. Fontosnak tartom megjegyezni, hogy a két kutató csoport tagjai között van átfedés. Az eredmények különbségére jelen esetben is az eltérő érzékelő felépítés ad magyarázatot. A citromsav és $\mathrm{NaCl}$ kölcsönhatásánál leírtakhoz (6.1. fejezete vége) itt még annyit érdemes hozzá tenni, hogy Tahara és munkatársai [2013] Na-glutamátot is vizsgáltak és eredményeik hasonlóak az Astree elektronikus nyelvvel kapottakhoz, azaz a $\mathrm{NaCl}$ és Na-glutamát hatása hasonló irányban változtatta meg a szenzor jeleket a koncentráció növekedésével. Az egyik kiemelten bemutatott érzékelő esetében mind $\mathrm{KCl}$ (sós), mind Na-glutamát hatására nő a szenzorjel. Az általuk vizsgált müszer szenzorai közötti különbség a membrán töltését meghatározó komponensekben volt és a $\mathrm{NaCl}$ és a Na-glutamát szenzor meglehetősen hasonló összetételü. 
Mindez azt jelzi, hogy eltérő elektronikus nyelv szenzorokkal is lehet hasonló mérési eredményeket kapni.

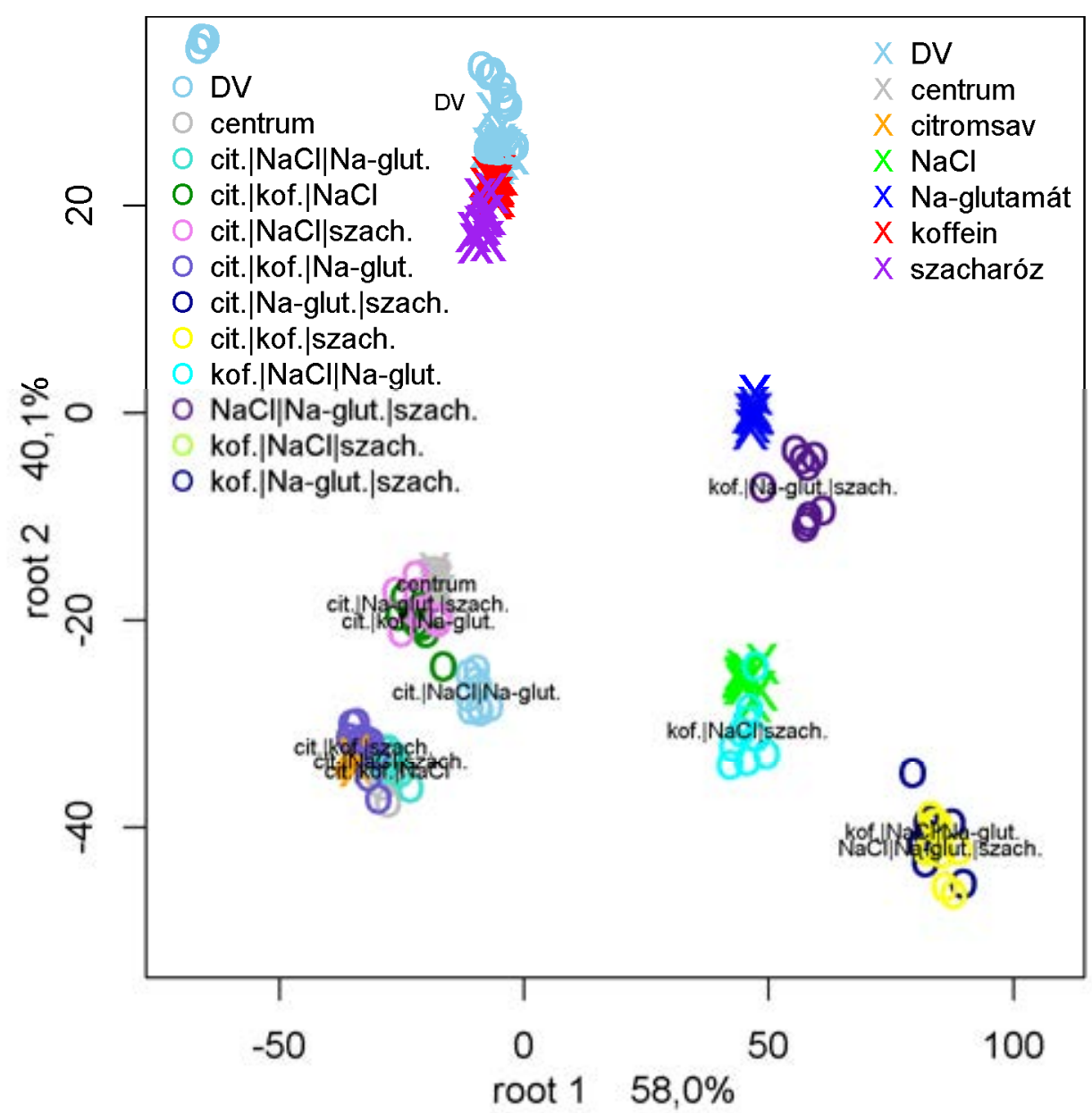

19. ábra Három komponensü modell oldatok eredményeinek projekciója az egykomponensủ modell oldatok alapján épített diszkriminancia modellbe.

\subsection{A koffein és a szacharóz kölcsönhatása más anyagokkal}

A keserü és az édes ízek kölcsönhatása igen fontos az elektronikus nyelv alkalmazhatóságának szempontjából. A koffein és a szacharóz hatása tiszta oldatokban is csak kis jelváltozást okoz ( 100 intenzitás érték, 7. ábra). Ez viszont nem jelenti, hogy a koffein vagy a szacharóz nem okozna szignifikáns jelváltozást és ne lehetne jól elkülöníteni ezeket a mintákat (amint azt a 22. ábra is bemutatja), csupán az abszolút jelváltozás kicsi.

A kétkomponensü modell oldatokat bemutató elemzésben (11. ábra) láthattuk, hogy a koffein és a szacharóz hatása csak 100 intenzitás értékkel módosítja a szenzorjeleket, ráadásul a diszkriminancia elemzés ábrája alapján csak a 3. diszkrimináns változó szerint különülnek el a koffein vagy szacharóz tartalmú és azok nélküli oldatok, miközben tudjuk, hogy különbségük szignifikáns (melléklet 1. ábra). Ennek oka, hogy az a diszkriminancia 
modell, ami a citromsavat, NaCl-ot és Na-glutamátot jól elkülöníti az a koffein és szacharóz elkülönítésére kevésbé alkalmas, mivel más szenzorok jelváltozásai dominálják a modellt.

A fent már bemutatott méréseken túl kísérleteket végeztem koffein, szacharóz, kinin és aszpartám minták tiszta és kettős kombinációival (koffein 0,195 g/L, szacharóz 5,76 g/L kinin 0,00269 g/L, aszpartám 0,0288 g/L). A kinin koncentrációt az emberi íz-küszöb értékének megfelelően határoztam meg. Az aszpartám az alkalmazott (5,76g/L) szacharóznak ekvivalens édességü (érzékszervi édesség) koncentrációban került a mérésbe [Magnuson és mtsai. 2007]. A kapott szenzorjelek közül itt (20. ábra) csak fontosabbakat emelem ki, de a mellékletben minden szenzor, hasonló módon elkészített elemzése megtalálható (melléklet 4. ábra). Az ábrán a következőket figyelhetjük meg:

1. Látható, hogy a mért minták szenzorjel intenzitásban kis különbségeket mutatnak a korábbi savas vagy ionos komponensekhez képest (néhány tíz $\leftarrow \rightarrow$ több száz)

2. Esetenként teljesen különböző ízü oldatok is egyformának tünnek és nem mutatható ki közöttük szignifikáns különbség egyetlen szenzor szerint sem, mint például a koffein és az aszpartám|szacharóz keverék között (t-próba, p>0,02, melléklet 5.ábra). Ez azt jelenti, hogy léteznek olyan oldat párok, melyek az ember számára könnyen megkülönböztethetőek, de elektronikus nyelvvel nehéz az elválasztásuk. A legjobb, irodalomban is megtalálható példa erre az édes ízzel kapcsolatos elektronikus nyelv kutatások, hiszen a szakma régóta küzd az édes ízt okozó vegyületek jobb mérhetőségének megoldásával. Tahara és mtsai. és Yasuura és mtsai. foglalkoznak részletesen a témával [Tahara Y. és mtsai. 2013, Yasuura Masato és mtsai. 2014]. Az egyes minták szenzor jeleinek nehezebb megkülönböztetése a kis szenzorjelet ( 100 intenzitás egység) produkáló minták esetében jöhet létre könnyebben, mivel ilyen esetben nagyobb a minták relatív szórása is.

3. A ZZ szenzor szerint a koffein|kinin és aszpartám|kinin aszpartám|koffein minta pár esetében a DV-nél nagyobb jeleket mérhetünk a tiszta komponensekre (kinin, koffein és aszpartám), azonban keverékben a különbség a DV-től nem jelentős (melléklet 4.ábra).

Mindez azt jelenti, hogy esetenként a tiszta komponensek szenzorokra gyakorolt hatásának ismeretében sem lehet megmondani, hogy egy keverék oldat hogyan fog viselkedni. Ez is azt bizonyítja, hogy az itt vizsgált koffein és szacharóz esetében fokozott jelentősége van az interakcióknak. 
$\mathbf{Z Z}$

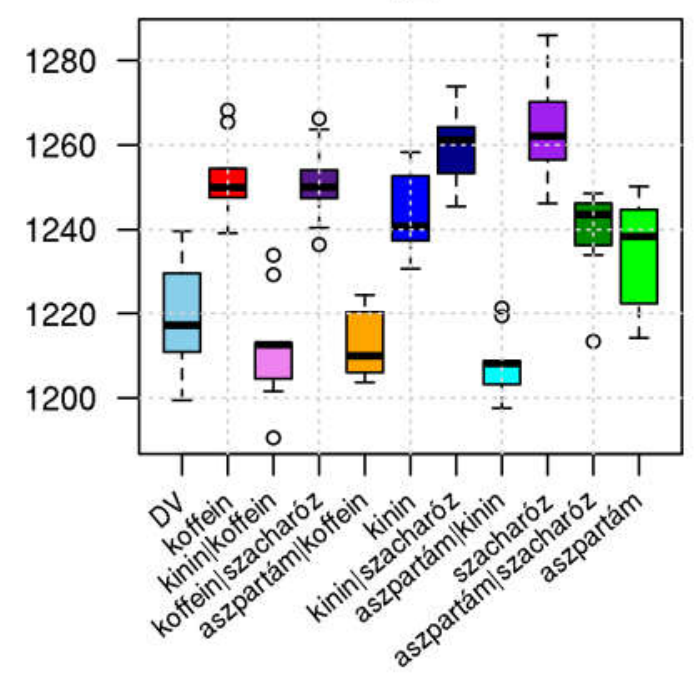

CA

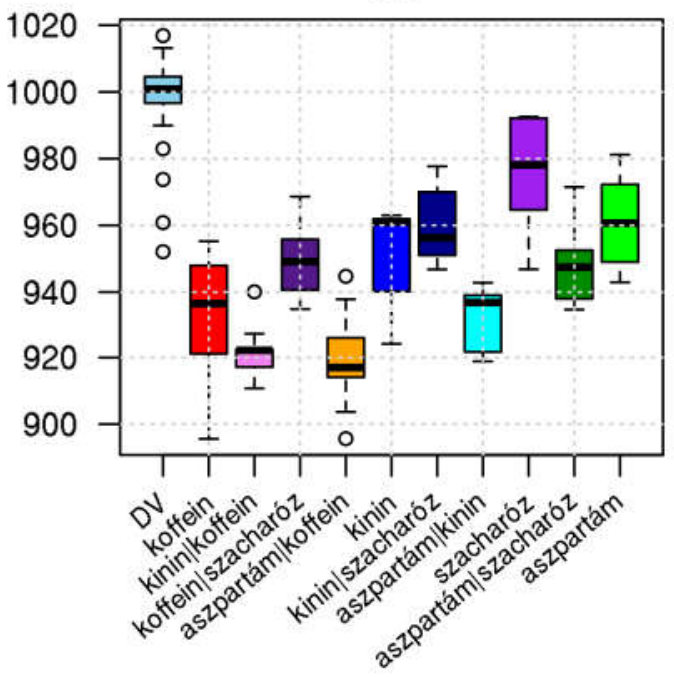

BB

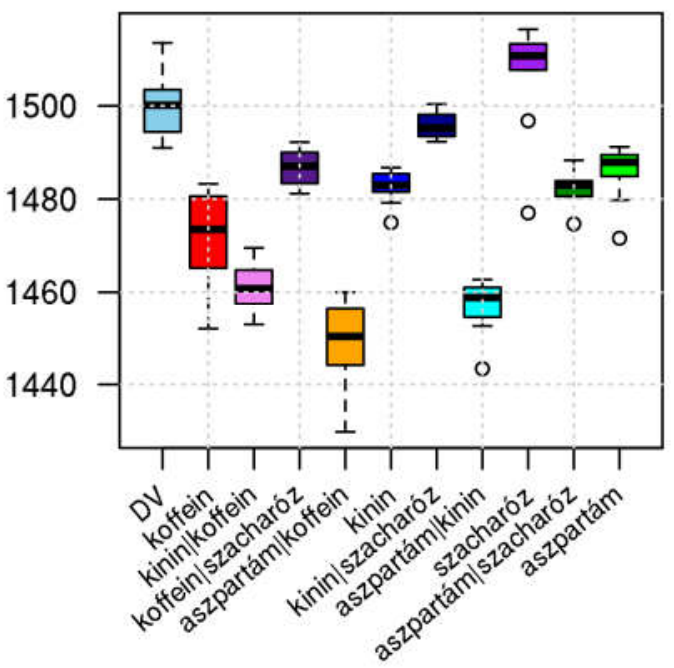

GA

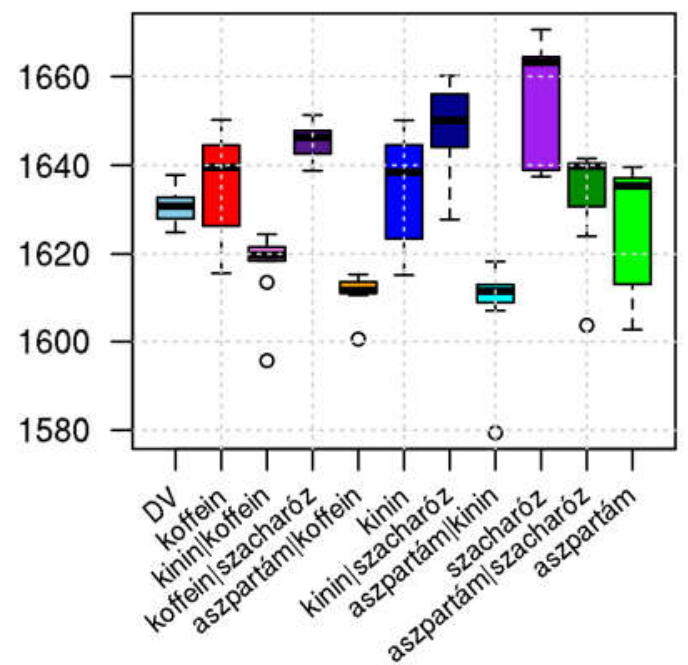

20. ábra Koffein szacharóz, kinin és aszpartám modell oldatok tiszta és kettős keverékeinek boxplot ábrája.

Mivel a kölcsönhatásoknak az édes és keserủ ízt okozó vegyületeknél láthatóan nagy szerepe van, elvégeztem egy csak koffeint (és természetesen a DV és centrum mintákat) tartalmazó mérést (az eredmények boxplot ábráját a melléklet 6. ábrája mutatja be). A mérés eredményeit felhasználva készítettem egy diszkriminancia modellt (21. ábra, mellékábra), mely a DV-et és a különböző koncentrációjú koffein oldatokat foglalta magába. Látható, hogy az első diszkrimináns változó (mely a csoportok közötti összes variancia 97,7\%-át tartalmazza) a növekvő koffein koncentrációt jelzi. Ha ebbe a diszkrimináns modellbe vetítem korábbi egy és kétkomponensủ mintáim mérési eredményit (21. ábra, föábra), akkor a koffein tartalmú mintáknak a koffein mentesekhez képest jobbra kell tolódnia, hisz mint említettem az első diszkrimináns változó a növekvő koffein koncentrációt jelöli ki. Azonban a tiszta koffein oldaton kívül (mely valóban a DV-hez képest jobbra foglal helyet), a koffein tartalmú minták 
nem különböznek a nekik megfelelö koffein mentes mintáktól (pl.: $\mathrm{NaCl}$ és koffein| $\mathrm{NaCl}$ ), tehát a koffein modell oldatokra épített diszkriminancia modell nem képes a koffein hatását kimutatni más vegyületek jelenlétében. Ennek magyarázata, hogy a koffein elektronikus nyelvre gyakorolt hatása más módon valósul meg citromsav, $\mathrm{NaCl}$ vagy $\mathrm{Na}$ glutamát jelenlétében, azaz a koffein hatása függ az oldatban előforduló egyéb anyagoktól is.

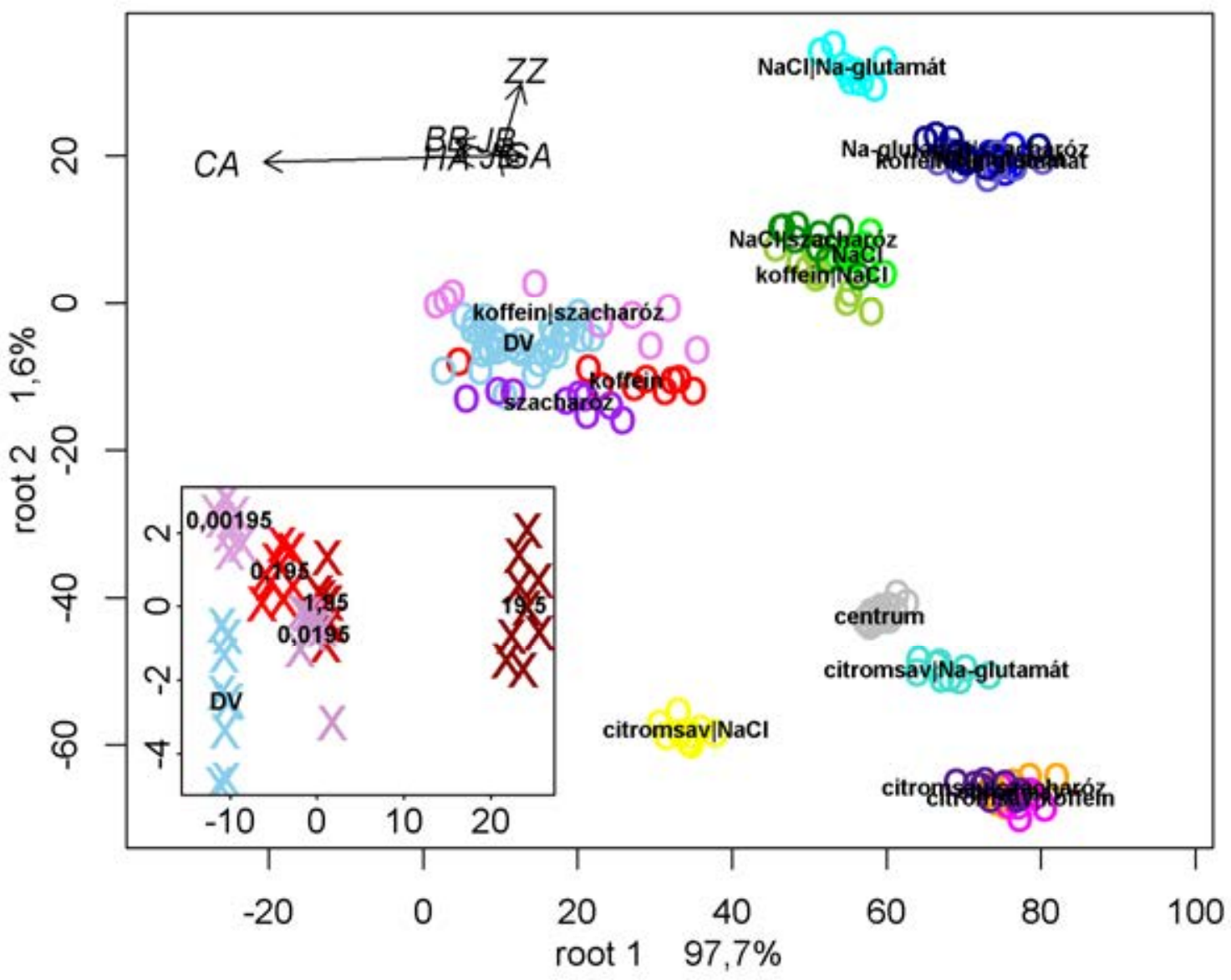

21. ábra Az egy és kétkomponensű modell oldatok adatainak projekciója a koffein koncentráció sorozatra épített LDA modellbe. Az alábra a kalibrációhoz használt koffein oldatok LDA eredményét mutatja g/L koffein koncentrációkat feltüntetve. A nyilak hossza az elektronikus nyelv szenzorok súlyát, irányuk pedig az eredeti szenzorjelekkel való korrelációját reprezentálja a diszkriminancia modellben. A modell koefficiensek megegyeznek mind két ábrán.

Az előbbi megállapításaim további bizonyítéka, ha azon minta hármasokat vizsgálom meg, melyek tagjai valamilyen 'törzsoldat' ( $\mathrm{DV}$, citromsav, $\mathrm{NaCl}$ vagy Na-glutamát) és a hozzájuk adott koffein vagy szacharóz. Ezen minta hármasokra épített diszkriminancia modellek rávilágítanak, hogy az egyes esetekben lehetséges-e a megkülönböztetés és ha igen, azokért mely szenzorok a felelősek. Az eredményeket a 22. ábra mutatja be és jól látható az 
elkülönülés. A diszkriminancia modellek helyes csoportba sorolási képessége rendre 97,2; 96,$3 ; 100 ; 96,3 \%$.
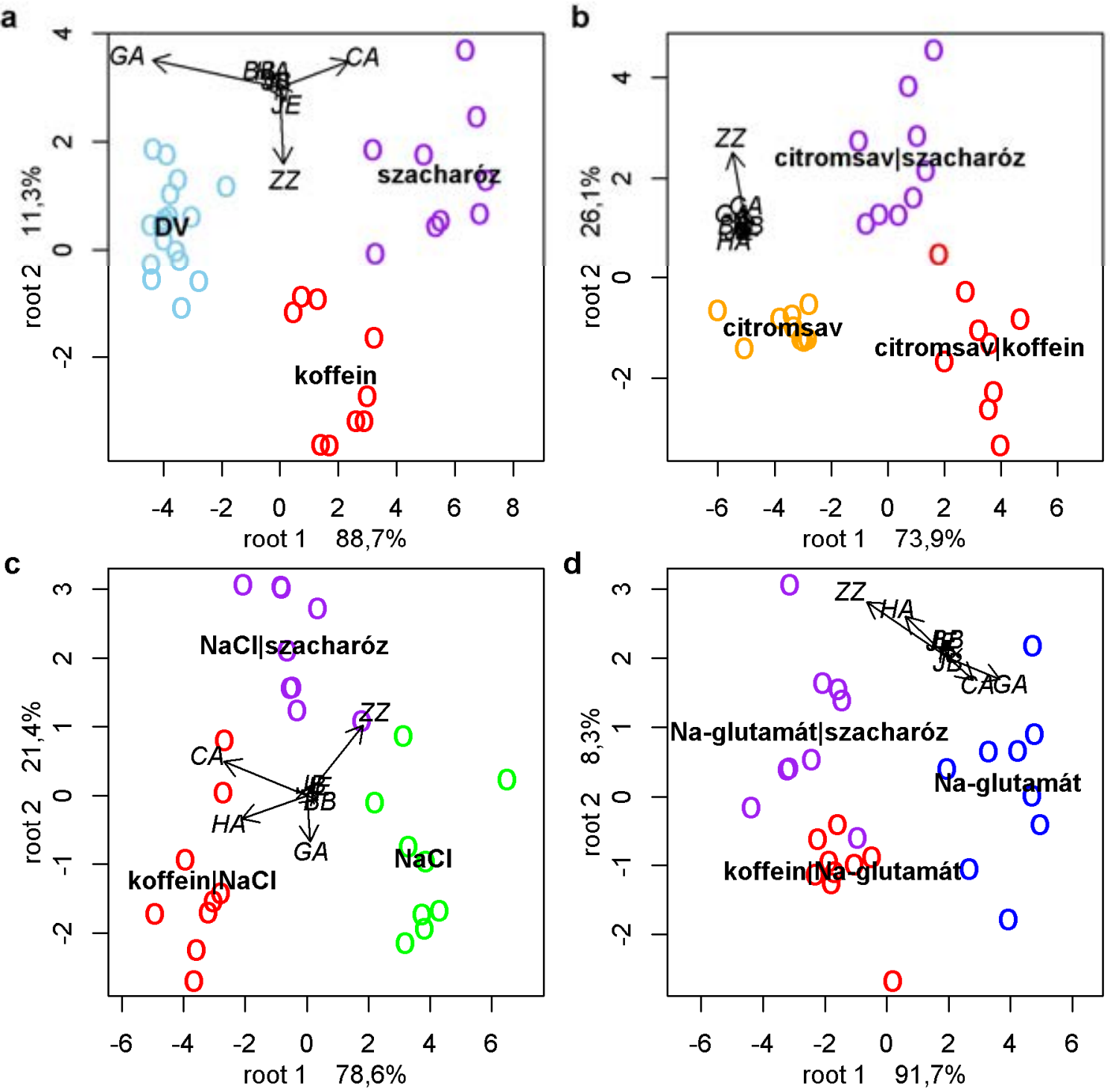

22. ábra Desztillált víz, citromsav, $\mathrm{NaCl}$ és Na-glutamát minták és koffeinnel vagy szacharózzal kiegészített kombinációinak lineáris diszkriminancia elemzés ábrái. A nyilak hossza az elektronikus nyelv szenzorok súlyát, irányuk pedig az eredeti szenzorjelekkel való korrelációját reprezentálja a diszkriminancia modellben.

A 22. ábrán az elektronikus nyelv szenzorok diszkriminancia modellbéli súlyuk ábrázolásával megfigyelhetjük a koffein és szacharóz tartalmú mintákat 'törzsoldatuktól' elkülönítő fontosabb szenzorokat is. Érdekes, hogy minden esetben más szenzor együttes felelős a minták elválasztásáért, ami arra enged következtetni, hogy a koffein és a szacharóz érzékelés nem kötődik szorosan egy szenzor szetthez, hanem az egyéb jelenlévő összetevők (és itt most a desztillált víz is ilyen) is meghatározzák a hatás mechanizmust. Ez azt is jelenti, hogy a koffein és a szacharóz interakcióin keresztül fejti ki hatását az elektronikus nyelv 
szenzorokra. Ezt a hatás mechanizmust az elektronikus nyelvvel kapcsolatban korábban még nem írták le.

\section{4İ́fokozás és íz-maszkolás}

Munkámban az íz-maszkolást az elektronikus nyelv szempontjából úgy definiálom, hogy a vizsgált oldat egyes összetevői látszólag nem hatnak a szenzorokra, (holott önmagukban mérhetőek) mivel más összetevők hatása elnyomja az okozott szenzorjelet. Ezt a jelenséget figyelhettem meg, mikor modell vegyületeim hármas kombinációit vizsgáltam. Míg a két modell vegyületet tartalmazó kombinációkban a citromsav|koffein - citromsav|szacharóz, $\mathrm{NaCl} \mid$ koffein - $\mathrm{NaCl}$ |szacharóz és Na-glutamát|koffein - Na-glutamát|szacharóz párok, ha kis értékkel is (rendre 17, 42, 71 intenzitás érték), de szignifikánsan különböztek (melléklet 1. ábra), addig a hármas kombinációkban, azon kombináció pároknál, ahol a 3. komponens koffein vagy szacharóz volt, csak a citromsav|koffein|Na-glutamát - citromsav|szacharóz|Naglutamát páros különbsége szignifikáns (euklideszi távolságuk 20, melléklet 3. ábra). A többi 2 esetben (citromsav|koffein $\mid \mathrm{NaCl}$ - citromsav| $|\mathrm{NaCl}|$ szacharóz és koffein $|\mathrm{NaCl}| \mathrm{Na}$-glutamát $\mathrm{NaCl} \mid$ szacharóz|Na-glutamát) a különbségek eltüntek, vagyis a koffein és a szacharóz hatása nem mutatható ki. A hasonlóságok megfigyelhetőek a három komponensü modell oldatok eredményeit, az egykomponensü oldatokból készített diszkriminancia modellbe vetítő ábrán is (19. ábra). Az eredmények az mutatják, hogy íz-maszkolást leginkább olyan anyagok szenvedhetnek el, melyek hatása mérsékeltebb ( 100 intenzitás érték) az elektronikus nyelv szenzorokra.

A tudományos irodalomban közvetett példákat lehet erre a jelenségre találni, Legin és munkatársainak 2009-es munkája, melyben megállapítják, hogy a legjobb ízmaszkoló hatása a vizsgált szőlőlének volt feltehetően azért, mert ez volt az egyetlen savas jelleget is hordozó és vizsgált maszkoló ágens és egyben ez az anyag a legjobban mérhető elektronikus nyelvekkel [Legin és mtsai. 2009]. Egy másik példa Riul és munkatársainak [2003] munkája melyben 1 mM-os HCl oldatot (hígabb mint az Astree kalibrációs oldata) sikerült maszkolni 17,1 - 102 g/L koncentrációjú szacharóz oldattal, ami meglehetősen magas koncentráció.

Az emberi íz-érzékelésben jól ismert jelenség az ízfokozás. A Magyar Élelmiszerkönyv definíciója szerint „Ízfokozók azok az anyagok, amelyek fokozzák az élelmiszerek meglévő ízét és zamatát." [2000]. Esetemben ízfokozásnak tekintettem, mikor egy bizonyos anyag hozzáadásával az élelmiszerben/mintában már eredetileg is jelenlevő anyagok hatását erősítettem fel. Az elektronikus nyelv szempontjából is elképzelhető olyan anyag, melynek mintákhoz adagolása fokozza bizonyos más összetevők hatását az elektronikus nyelv szenzorokra. Ez a jelenség mérési eredményeken úgy jelenhet meg, hogy egymáshoz nagyon 
hasonló mintákat kiegészítve valamilyen ízfokozó hatású anyaggal (természetesen az ízfokozót azonos koncentrációban adagolva) a minták közötti különbség megnő. Ebben az esetben is az összetevők összetett kölcsönhatásáról van szó, hiszen ha a hozzáadott anyag additívan módosítja a szenzorjeleket, akkor csupán némi eltolódást okozna a szenzorjelekben, de a minták közötti különbség változatlan maradna.

A jelenséget egy 2012-ben lemért, két 100\%-os kereskedelmi forgalomból származó 10szeresére hígított almalevet és $\mathrm{NaCl}$ kiegészített ( $5 \mathrm{~g} / \mathrm{L}$ ) változatukat vizsgáló kísérletben lehet megfigyelni. Az eredmények diszkriminancia elemzését a 23. ábra mutatja be és látható, hogy míg az almalevek önmagukban nem megkülönböztethetőek, de NaCl-dal kiegészítve azokká válnak. A szenzorjeleket t-próbával összevetve ugyancsak azt kapjuk, hogy a tiszta almalevek nem megkülönböztethetőek egymástól, azonban NaCl-os változatuk különbsége már szignifikáns. Az almalevek abszolút különbsége $\sim 10$ intenzitás érték, ami magyarázza a root 2 alacsony variancia hányadát.

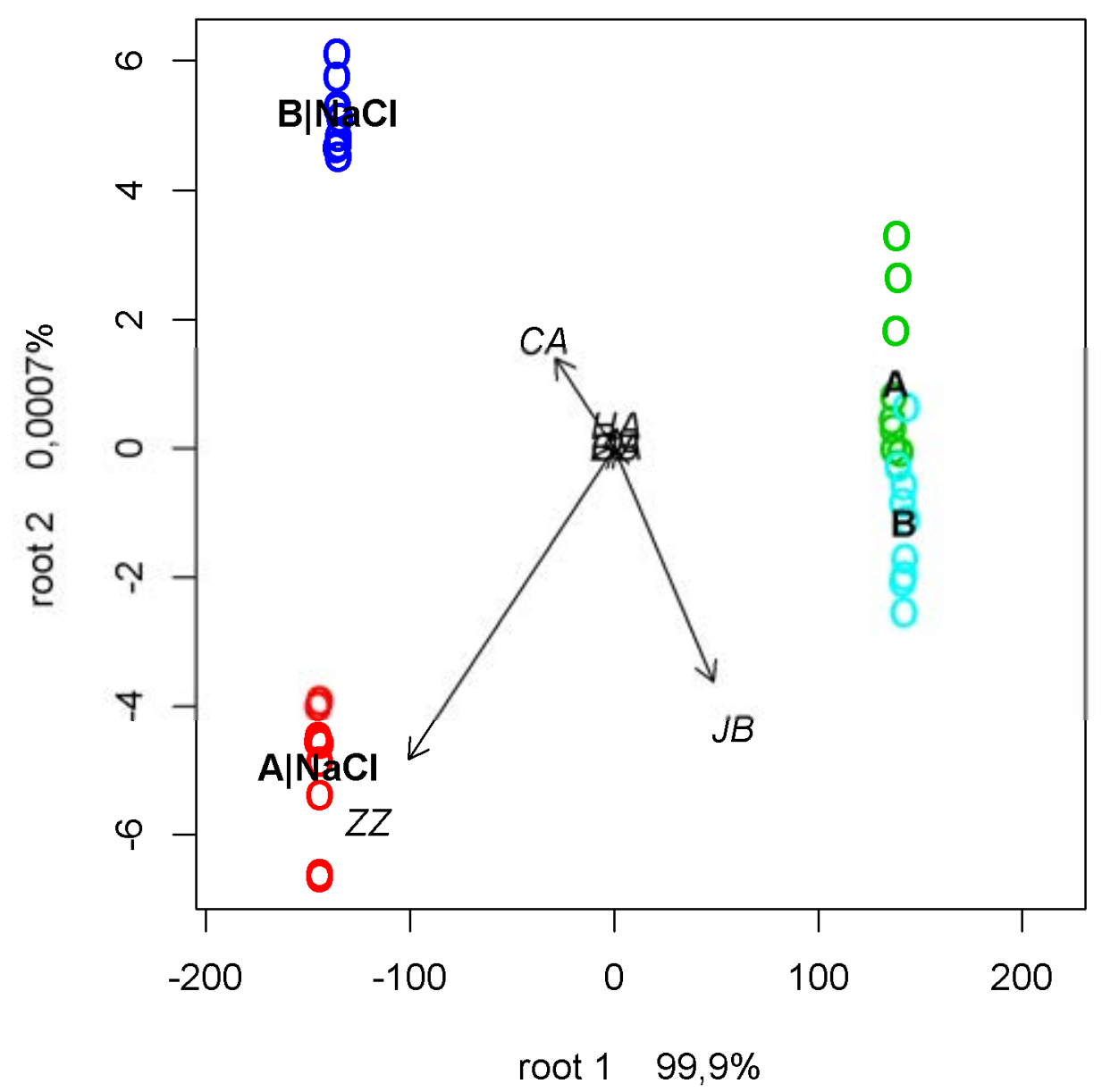

23. ábra Kereskedelmi forgalomból származó 100\%-os almalevek tisztán és NaCl-dal kiegészítve. A nyilak hossza az elektronikus nyelv szenzorok súlyát, irányuk pedig az eredeti szenzorjelekkel való korrelációját reprezentálja a diszkriminancia modellben. 
Fontosnak tartom megjegyezni, hogy az ízfokozás jelenségét feltehetően az elektronikus nyelvvel jól mérhető (DV-hez képest 1000 intenzitás érték változást okozó) anyagok kölcsönhatásai teszik lehetővé (az előbb említett esetben az almalé savassága a hozzáadott NaCl-dal).

\subsection{Kölcsönhatások koncentráció függése}

Vizsgálataim során felvetődött a kérdés, hogy két anyag interakciója mindig azonos jellegü vagy az interakcióban résztvevő anyagok koncentrációjától is függ. Természetesen kimutatható a koncentráció függés, mint ahogy azt már a citromsav $\mid \mathrm{NaCl}$ és $\mathrm{NaCl} \mid \mathrm{Na}$ glutamát több koncentrációjú kombinációinál is láthattuk. Az eddigiekben már bemutatott eredményeken kívül a koncentráció változás okozta kölcsönhatásbéli különbségeket többféle mérési összeállításban és régebbi élelmiszerekkel végzett mérésekben is tetten érhettem.

Elsőnek egy különböző koncentrációjú koffein oldatokat (19,5 g/L-től 1,95 g/L-ig, öt logaritmikus lépésben) és ugyan ezen oldatok $0,29 \mathrm{~g} / \mathrm{L}$ Na-glutamáttal kiegészített változatait tartalmazó mérés eredményeit mutatom be. A könnyebb összehasonlíthatóság kedvéért az ábrázolásban megjelenítettem a tiszta Na-glutamát jel intenzitását is (melyet az egykomponensű modell oldatok méréséből vettem át természetesen megfelelő korrekció után). A mért szenzorjelek közül a kiválasztott szenzorok eredményeit a 24. ábra mutatja be, természetesen az összes szenzor eredménye megtekinthető a mellékletben (melléklet 7. ábra). A koffein és a Na-glutamát koncentráció függő kölcsönhatásáról a következőket állapítottam meg:

1. A tiszta koffein eltérő koncentrációit a CA szenzor tudja a leginkább megkülönböztetni.

2. Nem egy folytonos tendencia alakult ki, hanem egy maximummal rendelkező elrendezés a ZZ, BB, CA és GA esetében. Ez arra utal, hogy az interakciónak szélső értéke van egy bizonyos koncentráció kombináció esetében ( $6,17 \mathrm{~g} / \mathrm{L}$ koffein és $0,29 \mathrm{~g} / \mathrm{L}$ Na-glutamát), ráadásul itt minden szenzor esetében ugyan annál a koncentráció párosnál.

3. Vannak olyan kombinációk, melyek bár eltérő koncentrációjú koffeint tartalmaznak, mégis hasonló jel intenzitást mutatnak egyes szenzorokra pl.: a $10,96 \mathrm{~g} / \mathrm{L}$ és a 3,47 g/L koffein tartalmú minták a BB szenzor esetében.

A koffein és a Na-glutamát nyilvánvalóan nem additívan hatnak egymásra, és a NaCl-dal való kölcsönhatásban is ugyan erre számíthattam kiindulva a $\mathrm{NaCl}$ és Na-glutamát esetében megfigyelt eredményekböl (12. ábra). A kölcsönhatás jól láthatóan függ a koncentrációtól és lehetséges, hogy két eltérő koncentrációban azonos szenzorjelet 
figyelhetünk meg egy adott szenzor esetében (ZZ; 19,5 és 0,95 g/L koffein), míg egy 'köztes' koncentrációban eltérö a kapott szenzorjel (ZZ; 6,17 g/L koffein).
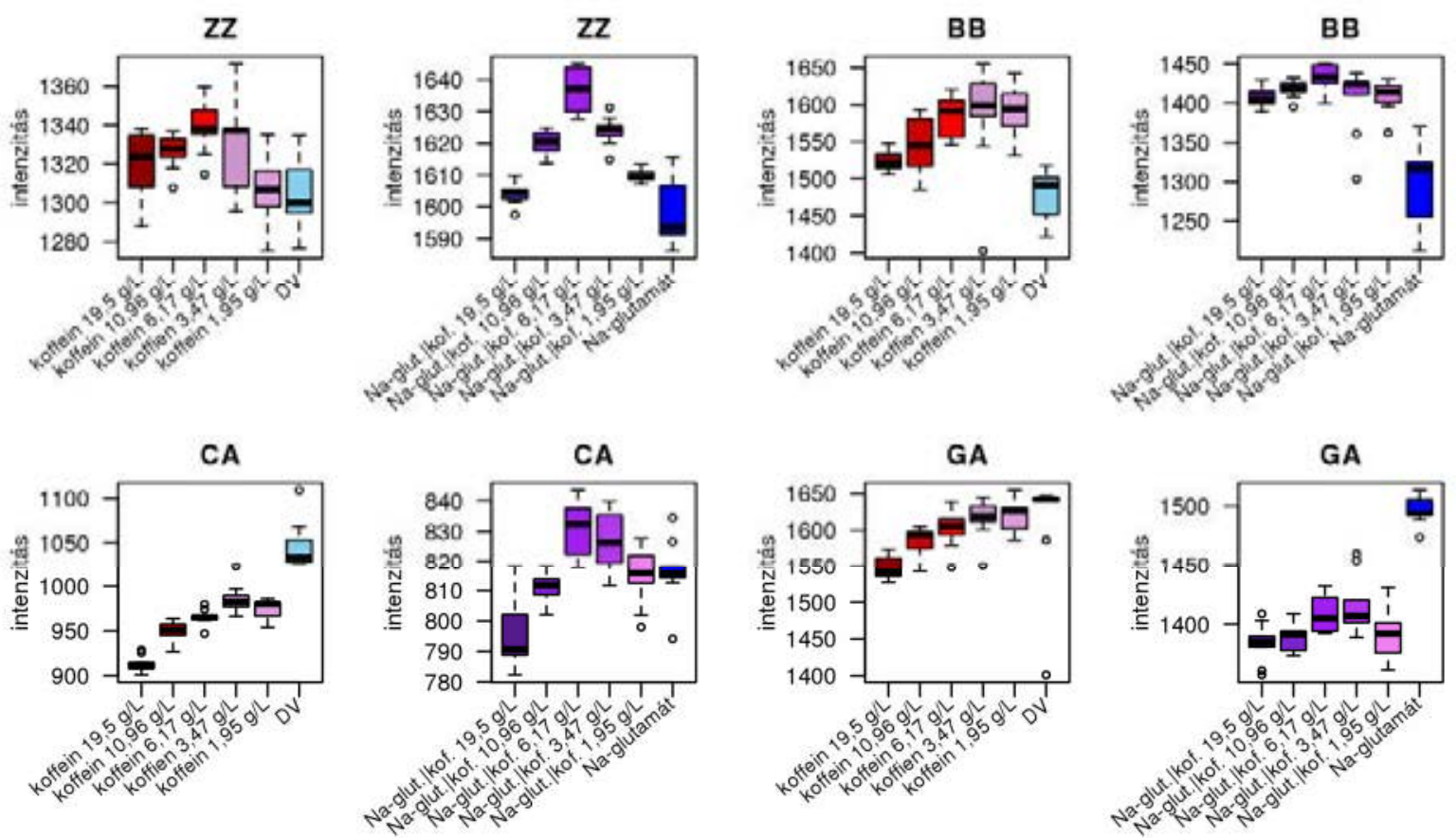

24. ábra Koffein hígítási sor tisztán és $0,29 \mathrm{~g} / \mathrm{L}$ Na-glutamáttal kiegészítve kiválasztott szenzorokra boxplot ábrán.

A 25. ábra 100\%-os paradicsomlé minta hígítási sorának szenzorjeleit mutatja a modell oldatoknál használt legújabb szenzorsorral. Bár egy igen összetett mintáról van szó, több szenzor esetében is jól elkülönülnek az egyes koncentrációk.

Ebben a mérésben is feltünik, hogy egyes szenzorok esetében a jelek tendenciája megfordul a koncentráció változásával (ZZ,CA), mint a koffein és Na-glutamát keverékek esetében, azaz a szenzorjel a koncentráció csökkenésével kezdetben csökken, majd egy szélsőérték elérése után nő. Egy ilyen 'fordulat' mutatja a legjobban az egyes összetevők kölcsönhatását és annak változását, mivel jelen esetben egy adott koncentrációban az egyik komponens (vagy komponens csoport) dominálja a szenzor jelét, addig más koncentrációban egy másik komponens veszi át a fó szerepet. Korábbi kutatásaink során többször is találkoztam ezzel a jelenséggel például szója italok esetében [Kovács és mtsai. 2009] vagy instant kávék különböző koncentrációjú mintáinál [Kovács 2007].

A modell oldatokkal végzett mérésekben (12. ábra tiszta $\mathrm{NaCl}$, tiszta citromsav) a savas minták a ZZ szenzorjeleit csökkentették a $\mathrm{NaCl}$ vagy Na-glutamát tartalmú minták pedig növelték a DV mintához képest. Jelen esetben azt láthatjuk, hogy az egészen híg paradicsomlevek a DV jelszintjének közelében helyezkednek el, amint az várható. A minták töményedésével a szenzor jelek közelítik a centrum minta jelszintjét, mely mint az 
egykomponensü modell oldatok mérési eredményeiből is tudjuk a citromsav mintához hasonlít a legjobban (8. ábra). A ZZ és kis mértékben a CA szenzor esetében azonban a legtöményebb (10\%-os) minta ismét távolabb helyezkedik el a centrum mintától. Ennek megfelelően azt állapíthattam meg, hogy a híg minták $(1 \mathrm{ml} / \mathbf{L} \mathbf{0 , 1} \mathrm{mL} / \mathbf{L})$ egy savas jellegü mintához hasonlítanak, azonban magasabb paradicsomlé koncentrációk esetében a gyárilag hozzáadott $\mathrm{NaCl}$ tartalom a savas jelleget fedi, amit a szenzorjel tendencia változásában lehet megfigyelni. A kölcsönhatás csak a legmagasabb mért koncentráció esetében megfigyelhető, tehát koncentráció függő.
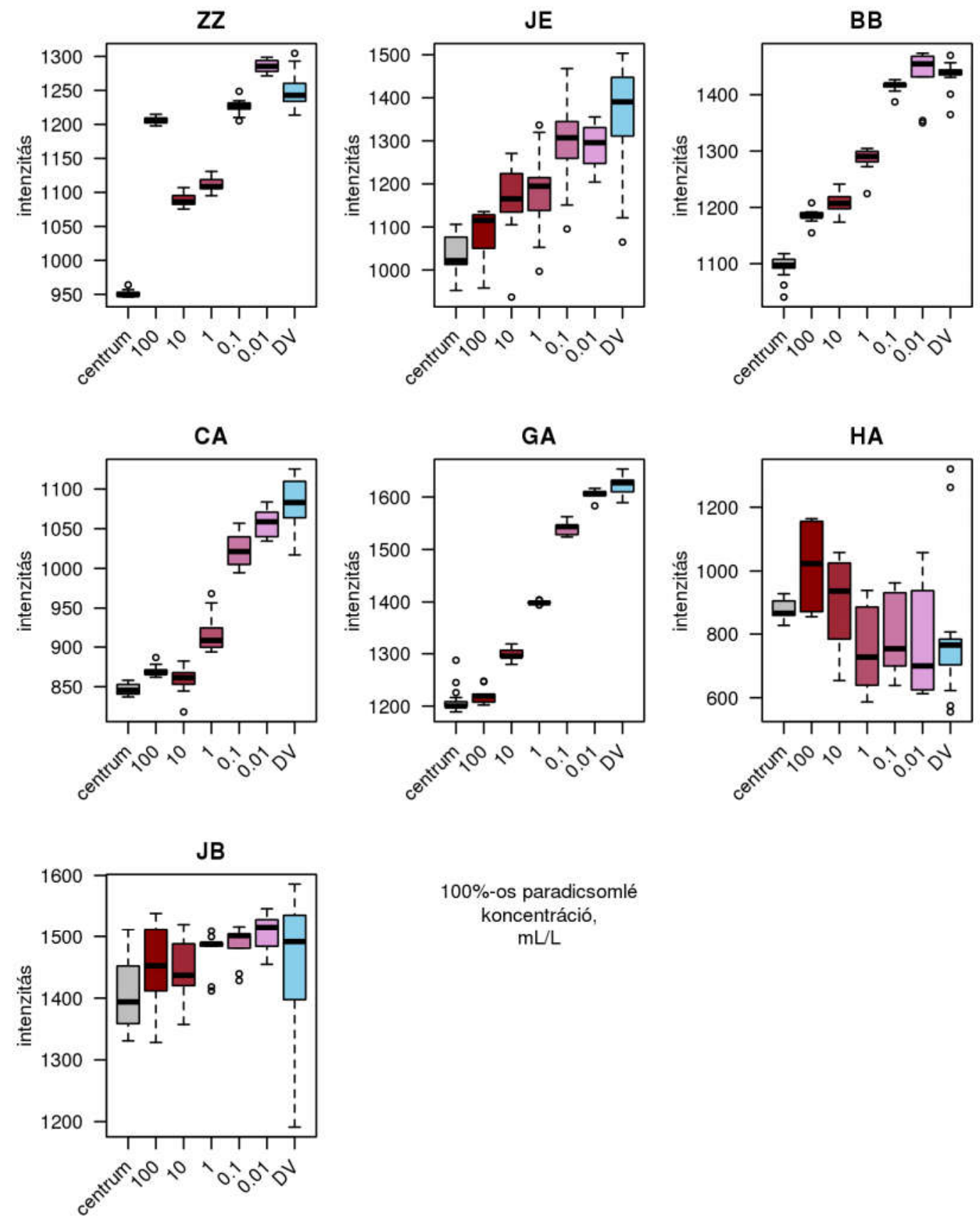
$100 \%$-os paradicsomlé koncentráció, $\mathrm{mL} / \mathrm{L}$

25. ábra 100\%-os paradicsomlé hígítási sora szenzoronként, hígítási sorrendben. Az x tengelyen a $\mathrm{mL} / \mathrm{L}$ paradicsomlé olvasható le. 

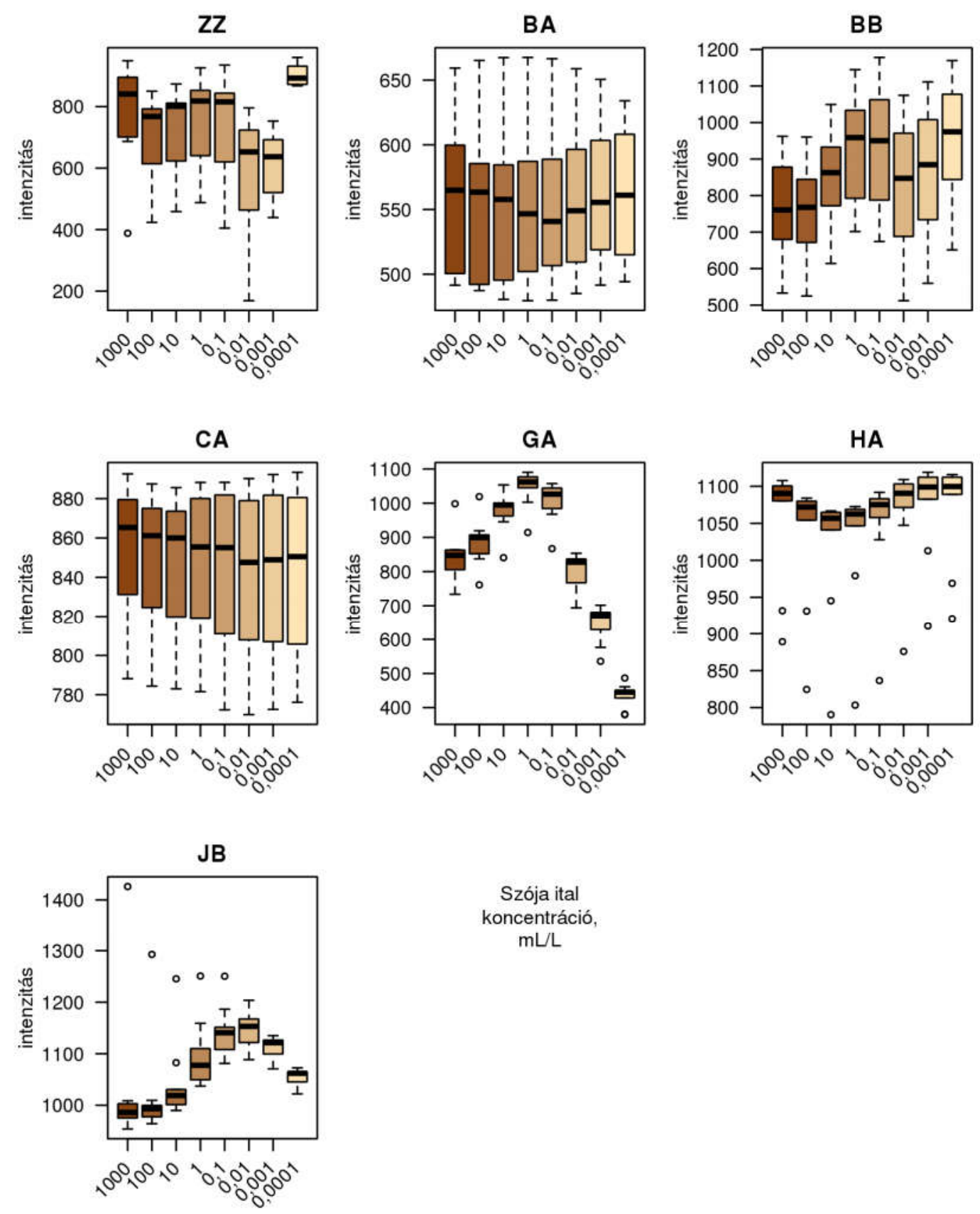

26. ábra Kereskedelmi forgalomból származó szója ital hígítási sora a Sor2009 szenzor sorral mérve. Az x tengelyen a mL/L szója ital koncentráció olvasható le.

A kölcsönhatások koncentrációfüggésének további bizonyitéka a már bemutatott 13. ábra, ahol látható, hogy a ZZ szenzor esetében minél magasabb a citromsav koncentráció annál kisebb a $\mathrm{NaCl}$ hatása a szenzorjelére (egymás fölött pontok távolsága balról jobbra csökken), melyet leginkább a ZZ szenzor esetében lehet megfigyelni, de valamelyest a BB és HA esetében is látszik.

A paradicsomléhez hasonlóan megvizsgáltam egy kereskedelmi forgalomból származó szója itallal készült régebbi mérést (2009-ben készült, a Sor2009 nevű szenzor sorral) 
melynek egy széles tartományú hígítási sorát mértem és a következőket figyelhettem meg (26. ábra):

1. Több szenzor esetében is (ZZ, GA, HA és JB) a szenzorjel intenzitásban a tendencia megfordulását láthatjuk, azaz koncentráció változásával a szenzorjelek intenzitása először az egyik irányba változik, majd egy szélsőérték elérése után megfordul.

2. Ez a szélsőérték szenzoronként eltérő koncentrációban található és a minta összetevők és az adott szenzor valamilyen különleges kölcsönhatására utalnak, melyek csak az adott koncentrációban figyelhető meg.

3. Az ilyen szélső értékek jelenléte a szója ital komponenseinek koncentrációfüggő kölcsönhatására mutatnak rá. Természetesen ez a kölcsönhatás az elektronikus nyelv szempontjából értendő.

4. Érdekes, hogy az igazán jelentős jel intenzitás különbségeket a 'szomszédos' hígítások között a hígabb minták esetében figyelhetjük meg.

Bár az eredmények itt egy eltérő szenzor sorral készültek a szenzorok alapvető felépítése hasonló és az oldatokra adott lehetséges jelválaszok csak kvantitatívan különböznek a később használt elektronikus nyelv szenzoroktól.

Egy újabb bizonyíték a kölcsönhatások koncentráció függésére egy korábbi szenzorsorral készült mérés (Specifikus szenzorsor), melyben kereskedelmi forgalomból származó 100\%-os almalé 10-szeres hígítását egészítettem ki glükóz és fruktóz keverékével (arányuk: 1:3 az összes hozzáadott keverék tömege: $0 ; 1 ; 2,5 ; 5 ; 10 ; 20$ g/L).

A 27. ábra az eredményeket szenzoronként mutatja be. Látható, hogy az almalé és a cukrok kölcsönhatása szintén szélsőértékkel rendelkezik az SRS szenzor esetében.

A fent bemutatott eredmények bizonyítják, hogy az elektronikus nyelvvel mért mintákban található összetevők megfigyelhető kölcsönhatásai koncentrációfüggők. A jelenséget több szenzorsor esetében is láthattuk. A kölcsönhatások jellegének változása több esetben is (koffein|Na-glutamát, paradicsomlé, almalé|cukor) egy nagyságrendnyi koncentráció változáson belül történt, de a szójaital esetében megfigyelhettünk ennél jóval lassabb ütemü (4-5 nagyságrend) változást is. 

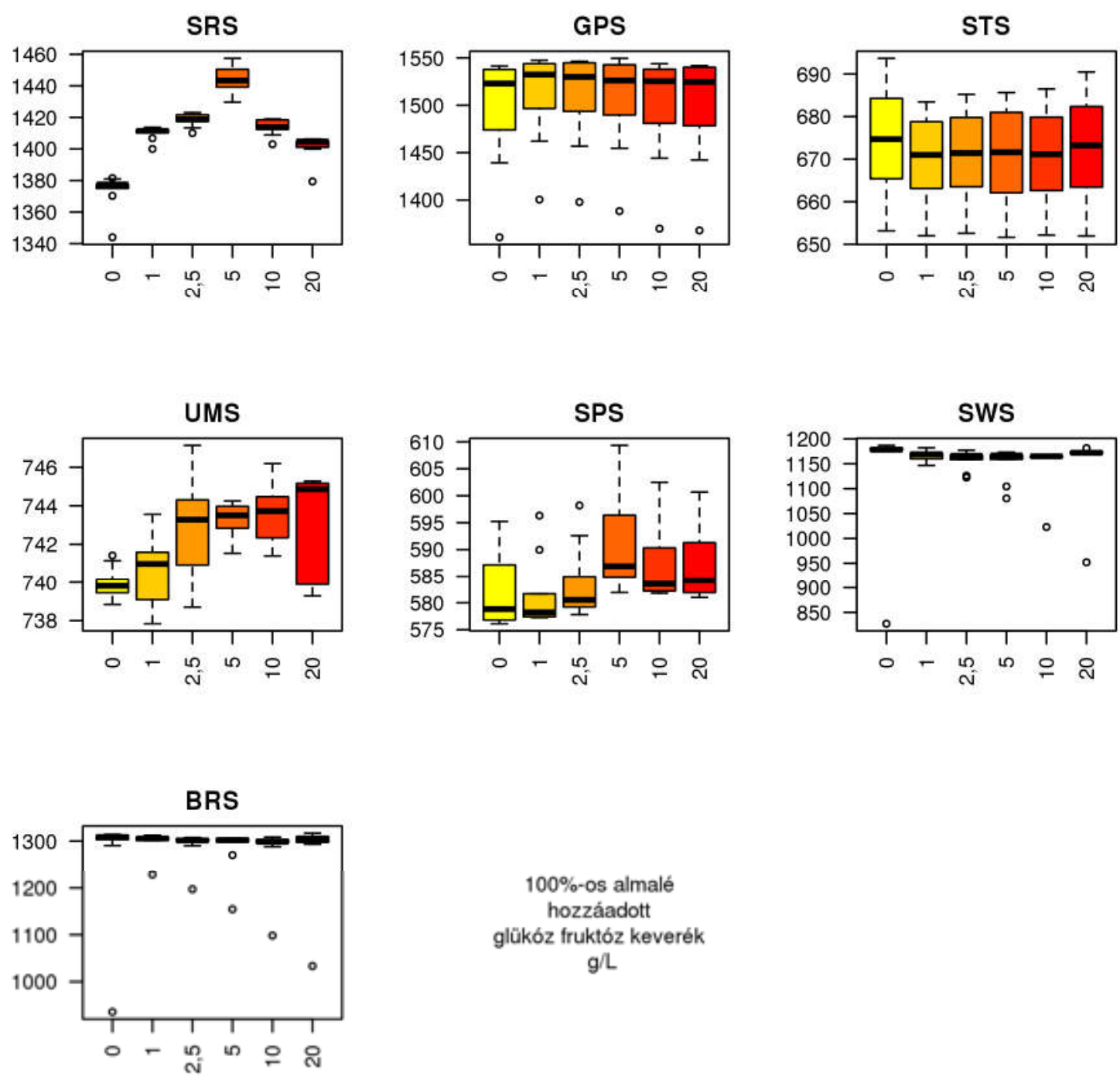

27. ábra 100\%-os almalé elektronikus nyelv eredményei hozzáadott glükóz-fruktóz keverékkel.

\subsection{Interakció mérési minták között}

A kölcsönhatásokat a korábbiakban kizárólag úgy értelmeztük, mint az egy mintában egyszerre jelenlévő összetevők egymásra hatását az elektronikus nyelv szenzorjeleinek szempontjából. Azonban ahogy korábban többször is foglalkoztam vele a mérések elemzését nehezíti a folyamatosan jelenlevő különböző mértékủ drift. Ezen felül, ahogy az anyagok és módszerek (5.1.1) fejezetben is leírtam az elektronikus nyelvet használat elött kondicionálni szükséges, hogy a száraz szenzorok 'hozzászokjanak' a vizes oldatban történő méréshez. Ez a kondicionálás híg sósavval történik tehát gyakorlatilag egy savas (savanyú) oldathoz szoknak hozzá a szenzorok. A kondicionálási folyamat nem áll meg a mérések során sem. Ennek az a következménye, hogy azon mérések összehasonlításánál melyekben markánsan eltérő jellegü 
minták vannak (pl.: csak savas minták az egyik mérésben és csak sósak a másikban) még kevésbé hozhatóak fedésbe utólag, mivel a szenzorok a mérés során a mintához kondicionálódnak. A jelenség hasonlít ahhoz, mikor egy élelmiszer ízét befolyásolja egy korábban fogyasztott másik élelmiszer íze (pl.:citromlé után a csapvíz édesnek hat) [Lawless és mtsai. 2010]. A 28. ábra ezt a jelenséget mutatja be. Ahhoz, hogy láthassuk a szenzorjelek eltolódásának mértékét az egykomponensủ modell oldatok adataiból diszkriminancia elemzést készítettem. Ebbe a modellbe vetítettem olyan mérési eredményeket, melyek szintén tartalmaztak azonos egykomponensü oldatokat (pontosan abban a koncentrációban, ahogy a modell építéshez használt mérésben is jelen voltak). Amennyiben nincs félre kondicionálódás, úgy az azonos oldatoknak egybe kell esni. A modellbe a $\mathrm{NaCl}$ hígítási sor, a citromsav és $\mathrm{NaCl}$ különböző koncentrációjú keverékeinek és a $\mathrm{NaCl}$ és Na-glutamát különböző koncentrációjú keverékeinek mérési eredményeit vetítettem természetesen korrekció után. A modellbe vetített mérési eredmények között több olyan minta is szerepel, mely mind a négy mérésben benne volt (centrum, $\mathrm{DV}, \mathrm{NaCl} 0,119 \mathrm{~g} / \mathrm{L}$ ). Az ábrán az figyelhető meg, hogy a DV mintát a korrekciónak köszönhetően megfelelő helyre becsülte a diszkriminancia modell (a centrum mintának mindenképpen jó helyre kellett kerülnie hisz erre korrigáltam az eredményeket). A NaCl sorozat esetében (a) a minták egy folytonos sorozatot alkotnak a DV mintától kezdődően egyre töményedő rendben és a $0,119 \mathrm{~g} / \mathrm{L}$ koncentrációjú minta is tökéletes fedésben van a diszkriminancia modell építéséhez használt azonos koncentrációjú $\mathrm{NaCl}$ mintával (az ábrán X). A szenzorjelek nem kondicionálódtak félre ezen mérés során.

A b alábrán a citromsavat és NaCl-ot tartalmazó különböző koncentrációjú keverékek mérésének eredményeit mutatom a diszkriminancia modellbe vetítve. Ebben a mérésben a centrum, $\mathrm{DV}$ és $\mathrm{NaCl}$ mintákon kívül a tiszta citromsav oldat is jelen volt mind a modell építéshez használt, mind a bevetített mérésben. Látható, hogy ebben az esetben a $\mathbf{N a C l}$ mintát nem sikerül helyesen megbecsülnie a diszkriminancia modellnek (a citromsavat igen), melynek oka a fent említett mérés közbeni kondicionálódás. Fontos megjegyezni, hogy egyrészt ez a mérés hosszabb volt, hiszen több mintát mértem benne. Másrészt a minták kétféle anyag keverékei voltak ellentétben a $\mathrm{NaCl}$ hígítási sorral. Ezt azért fontos kiemelni, mert az alkalmazott drift korrekciós módszer arra a feltételezésre épít (jobb híján), hogy a korrigálandó drift egyenletes ütemü és egyirányú. Ez azt jelenti, hogy ha egy szenzor a drift során csökkenő jelintenzitást mutat a mérésben előre haladva, akkor ez nem változik sem mértékben sem előjelben a mérés végéig. Egykomponensü oldatok esetén ez könnyebben valósul meg, hiszen csak egy komponens hat a szenzorokra és így a korrekció is hatékonyabb.

Megállapításaimat támasztja alá a c alábra ahol a diszkriminancia modellbe a $\mathrm{NaCl} / \mathrm{Na}$ glutamát keverékek mérési eredményeit vetítettem. Bár a DV mintát megfelelő helyre 


\section{becsülte a modell, az egykomponensü méréssel közös $\mathrm{NaCl}$ és Na-glutamát minták}

egyikét sem sikerül helyesen megbecsülni. Figyelembe véve, hogy a $\mathrm{NaCl}$ és a Na-glutamát korábbi eredményeim szerint még hasonlóan is viselkednek, a 'félre kondicionálódás' ebben a mérésben jöhet létre a legkönnyebben. Ezt a feltevést tovább erösíti, hogy mind a $\mathrm{NaCl}$ mind a Na-glutamát becsült helyének eltérése azonos irányú és a legtöményebb C3 jelü minta felé mutat (fekete nyilak). Ezek az eredmények azt is demonstrálják, hogy eltérő driftet figyelhetünk meg eltérő oldatokra (centrum $\leftarrow \rightarrow \mathrm{NaCl}$ ), mivel a centrum mintára történt korrekció nem korrigálja helyesen a $\mathrm{NaCl}$ és a Na-glutamát minták driftjét.

Amennyiben megvizsgáljuk kísérleteim során lemért minták nyers adataira alkalmazott korrekció szenzoronkénti és összegezett mértékét (5. táblázat) a következő megfigyeléseket tehetjük:

1. A hosszabb (több minta) mérési szekvenciák nagyobb összegzett korrekciót igényeltek.

2. Az egykomponensü modell oldatok mérési eredményeit kellett a legkisebb mértékben korrigálni. Az összes mérés közül drift szempontjából ezek voltak a legkiegyensúlyozottabb mérések.

3. A legnagyobb driftet a $\mathrm{NaCl}$ és Na-glutamát különböző koncentrációjú keverékeinél figyelhettem meg szenzorokra lebontva és összegezve is.

4. Az egyes mérésekben nem csak a drift mértéke volt eltérő, de a szenzorok érintettsége is különbözött a minták jellegéből kifolyólag.

5. táblázat A nyers adatok korrekciója során szenzoronként alkalmazott korrekciós értékek és azok négyzetösszegének gyöke. Az abszolút értékben legnagyobb három értéket oszloponként színesen is kiemeltem.

\begin{tabular}{|c|c|c|c|c|c|c|c|c|c|}
\hline mérés & $\mathrm{ZZ}$ & JE & $\mathrm{BB}$ & $\mathrm{CA}$ & GA & HA & JB & $\sqrt{\Sigma\left(X^{2}\right)}$ & szekvencia \\
\hline egykomponensü modell oldatok & 20 & 26 & 8 & -1 & -78 & 7 & -40 & 94 & klasszikus \\
\hline $\mathrm{NaCl}$ hígítási sor & 47 & -4 & 70 & 27 & -140 & 32 & -68 & 182 & klasszikus \\
\hline koffein hígítási sor & 24 & 151 & 16 & -3 & -68 & 88 & 4 & 189 & klasszikus \\
\hline kétkomponensü modell oldatok & 28 & -166 & 15 & 44 & -154 & 8 & -95 & 251 & kibővített \\
\hline $\begin{array}{l}\text { citromsav és } \mathrm{NaCl} \text { különböző } \\
\text { koncentrációjú keverékei }\end{array}$ & 4 & -33 & -44 & -25 & -166 & 43 & -172 & 250 & kibővített \\
\hline $\begin{array}{l}\mathrm{NaCl} \text { és Na-glutamát különbözö } \\
\text { koncentrációjú keverékei }\end{array}$ & 63 & -72 & 149 & 51 & -185 & -19 & -17 & 262 & kibővített \\
\hline $\begin{array}{l}\text { koffein hígítási sor tisztán és Na- } \\
\text { glutamáttal kiegészítve }\end{array}$ & 40 & -100 & 47 & 2 & -166 & -92 & -20 & 224 & kibővített \\
\hline paradicsomlé hígítási sor & 55 & 90 & 47 & -53 & -142 & -156 & -36 & 249 & kibővített \\
\hline
\end{tabular}



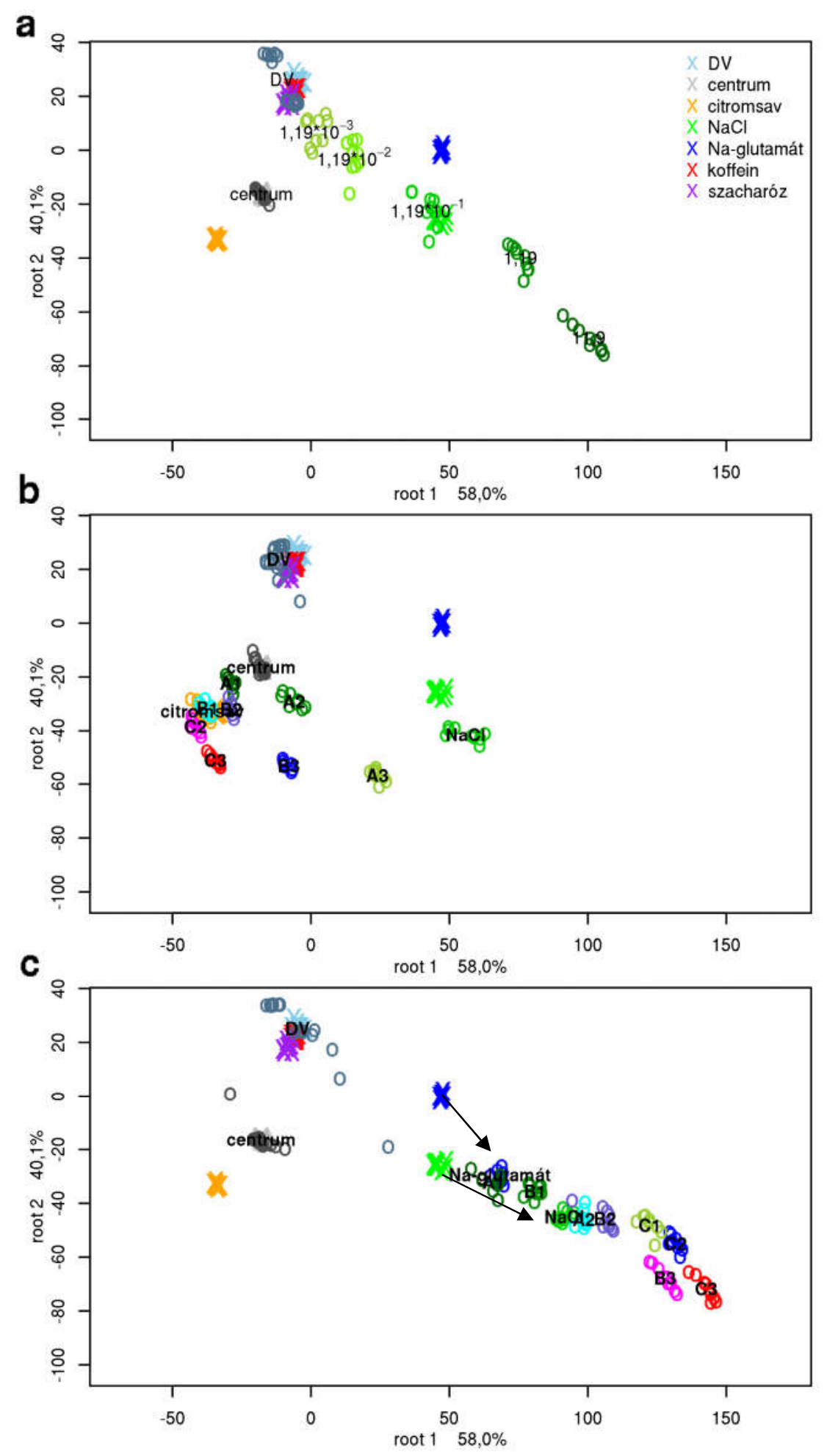

28. ábra Az egykomponensü modell oldatok mérési eredményeinek diszkriminancia elemzése és az így kapott diszkriminancia modellbe vetített $\mathrm{NaCl}$ hígítási sorozat (a), citromsav és $\mathrm{NaCl}$ keverékek (b) és $\mathrm{NaCl}$ és Na-glutamát keverékek mérési eredményei (c).

A fejezetben bemutatott eredmények alapján kijelenthetem, hogy interakció létrejöhet úgy is, hogy az interakció résztvevői nincsenek egy mintatartó pohárban, mivel egy minta elhelyezkedését a szenzortérben meghatározza a többi ugyanazon mérésben részvevő minta is. 
Ez a hatás hosszabb mérések kivitelezésekor még kifejezettebb. Láthattuk azt is, hogy lényeges a mérésben részvevő komponensek száma és minősége mind a drift mértéke, mind a korrigálhatósága szempontjából. Amennyiben szükséges eltérő mérések összehasonlítása, érdemes minden mérésbe kiegyensúlyozottan elrendezni a mintákat, hogy a teljes palettát tartalmazza minden egyes mérési alkalom. Mivel az előző fejezetek eredményeit olyan mérési eredményekre alapoztam, ahol több féle koncentrációban és kombinációban is jelen voltak a minták a tiszta komponensekkel együtt és egy mérési alkalommal mértem ezeket, a minták összevethetőek maradtak és a kölcsönhatások is megfigyelhetőek. A minták véletlen mérési sorrendje biztosította, hogy a félre kondicionálódás egyformán érintsen minden vizsgált mintát.

Mindazonáltal soha nem szabad megfeledkezni arról, hogy egy mintára kapott abszolút szenzorjeleket befolyásolja a mérésben résztvevő összes minta és ezért a szenzorjel különbségek hordozzák a lényeges információt. A kölcsönhatások vizsgálatánál érdemes a tiszta komponenseket is vizsgálni, melyek szenzorjelére ugyanazok a hatások érvényesülnek és mintegy belső standardként müködnek.

A félre kondicionálódást okozó érzékelő drift egyik komponense feltehetően a szenzorok memória effektusa, de a hatás erősségét és irányát a mért minták minősége határozza meg. Emiatt úgy gondolom, hogy még akkor is kölcsönhatásról beszélhetünk, ha valójában csak a szenzorok memória effektusáról lenne szó. A szenzorok felületén lejátszódó folyamatokat befolyásolják az összetevők kölcsönhatásai (pl.: egy vegyület jobb kötődése akadályozhatja más vegyületek kötődését, hisz a szenzor felülete véges) és ezáltal a memória hatást is.

\subsection{Módszer elektronikus nyelvvel mért oldatok összetevöi közötti kölcsönhatások kimutatására és elemzésére}

A megelőző fejezetekben bemutatott eredmények bizonyítják, hogy egy viszonylag egyszerü mérési összeállítással és elemzéssel hatékonyan vizsgálható az Alpha Astree elektronikus nyelvet érintő oldat összetevők közötti kölcsönhatás. Egy ilyen vizsgálat tárgya lehet két kémiailag tiszta vegyület oldata (mint jelen munkámban), de semmi akadálya nincs annak, hogy a kölcsönhatásokat összetett oldatok között vizsgáljuk (például gyümölcslevek, borok, stb.). A kidolgozott módszer lényeges különbsége a gyártó által javasolthoz képest, hogy a mérésben referencia mintákat is mérek a mérés elején és végén is, melyet aztán korrekcióra használok fel. A 29. ábra az előző fejezetben bemutatott egy komponensű modell oldatokra építetett diszkriminancia modellbe vetített citromsav és $\mathrm{NaCl}$ különbözö koncentrációjú keverékeinek eredményeit mutatja korrekció nélkül (a) és korrekcióval (b). 
Az ábrán megfigyelhető a mérés során lejátszódó drift, melyet a minta pontok elnyújtott elhelyezkedése mutat, a különböző minták esetében közel azonos irányban. A korrekció segítségével ez az elnyújtott elrendezés jelentősen csökkenthető, mely összességében a minta pontok kisebb szórásához és ezáltal jobb megkülönböztethetőségéhez járul hozzá.

A mérések közötti szenzorjel eltolódás ugyancsak látható, hisz az egykomponensü mérésben és a keverékeket vizsgáló kísérletben a $\mathrm{DV}$, centrum, citromsav és $\mathrm{NaCl}$ minták azonosak voltak, korrekció nélkül viszont ezek egyike sem esik egybe. A korrekció alkalmazása után a citromsav, centrum és DV minták fedésbe kerültek és a $\mathrm{NaCl}$ mintapontjai is jóval közelebb kerülnek egymáshoz így a korrekció alkalmazása mindenképpen javított az eredmények összevehetőségén.
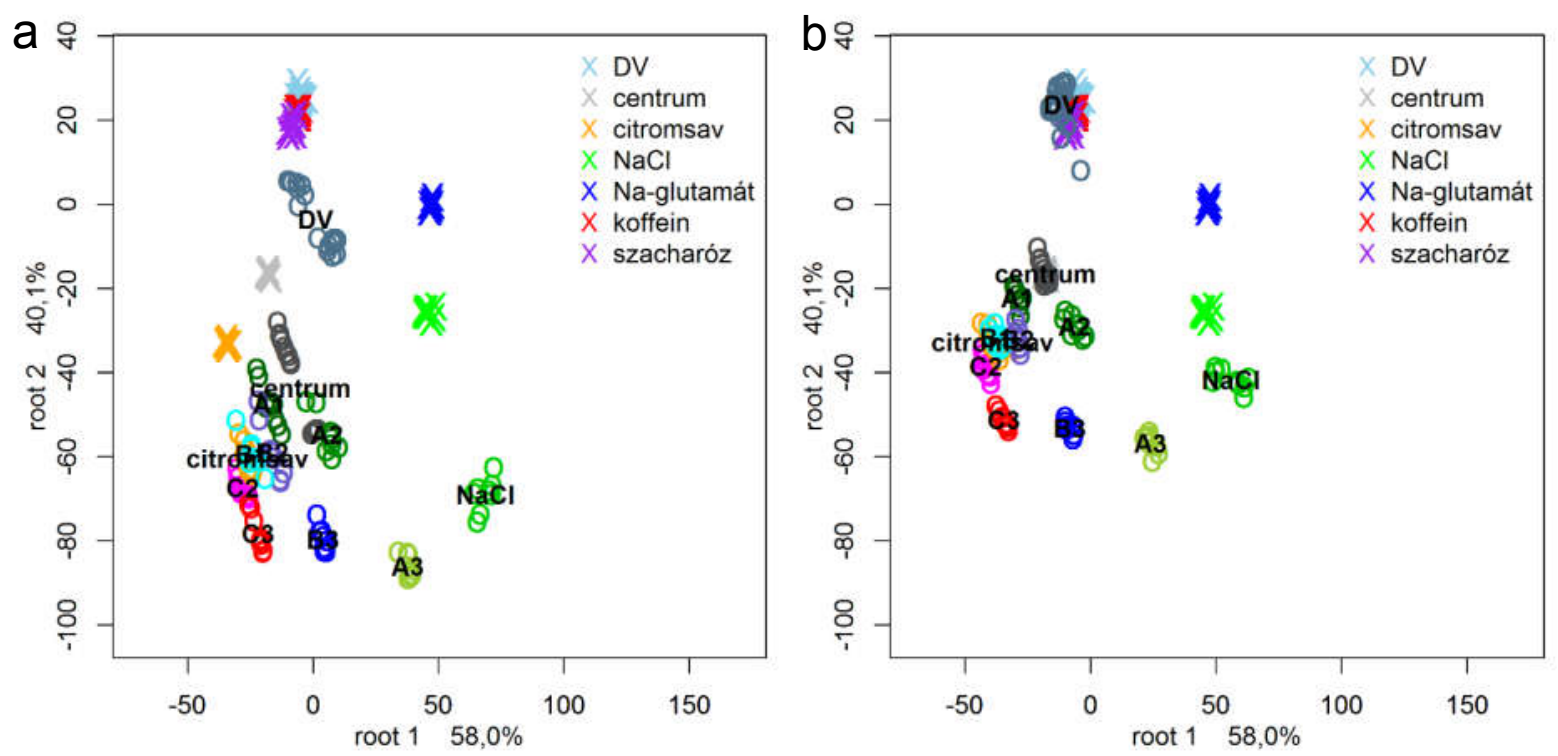

29. ábra Az egykomponensủ modell oldatok mérési eredményeinek diszkriminancia elemzése és az így kapott diszkriminancia modellbe vetített citromsav és $\mathrm{NaCl}$ keverékek mérési eredményei korrekció nélkül (a) és korrekcióval (b).

Az általam alkalmazott adatkiértékelés is eltérő volt a szokásostól, mivel részletes szenzor szintü elemzéseket is végeztem, valamint a minták összehasonlításában az irodalomban is egyre gyakrabban alkalmazott euklideszi távolságokat [Ito és mtsai. 2013, Legin és mtsai. 2009] is kiszámítottam és elemeztem. A kölcsönhatások vizsgálata során a kapott eredmények sokszor igen elgondolkodtatóak és elsőre nehezen magyarázhatónak tüntek azonban kellő körültekintéssel és a vizsgálataim során használt módszer új mintákra való alkalmazásával már könnyebb helyzetbe kerülhet az elektronikus nyelv kölcsönhatásait vizsgáló kutató.

A módszer kritikus pontjai a következőek: 
- A vizsgált komponensek tisztán és kombinációban is, lehetőleg több (releváns) koncentrációban legyenek jelen. Tiszta komponensek esetén érdemes az emberi ízküszöb érték közelében és annál valamivel magasabb koncentrációkban mérni, hisz előbb utóbb az ember által érzékelhető ízekre vonatkoztatjuk az eredményeket. Íz-küszöb értékeket a tudományos szakirodalomban, de az elektronikus nyelv technikai leírásaiban is találhattam [AlphaM.O.S. 2002a].

- Kontroll minták használata, mint amilyen a desztillált víz és egy a minták 'átlagát' képviselő oldat, ami lehet az egyik keverék is. Ez lehetővé teszi a mérés korrekcióját és más mérésekkel való összevethetőségét is. A korrekció során érdemes figyelembe venni a mérések közötti driftet és hosszú mérések esetén a mérés alatt lejátszódó szenzorjel eltolódást is.

- A kontroll mintákat a mérés elején és végén is érdemes lemérni a desztillált vízzel kezdve a sort így elkerülhető az áthordásból eredő hiba. Az interakcióban érintett oldatok esetében véletlenszerü mintasorrend alkalmazása szükséges a szisztematikus hibák elkerülésére. A dolgozatban bemutatott mérési szekvenciák a későbbiekben hasznosíthatóak erre a feladatra.

- Az eredmények elemzését érdemes és szükséges szenzorokra lebontva és együttesen diszkriminancia elemzéssel vagy más jól bevett többváltozós módszerekkel vizsgálni (pl.: főkomponens elemzés). Itt az is kiderül. hogy mely szenzorok a leginkább érintettek az interakciókban és megfigyelhetőek az esetleges hasonlóságokat korábbi mérési eredményekkel.

- A hatások PLS regresszió segítségével számszerüsíthetőek. Amennyiben egy tiszta komponens koncentrációjában akarjuk a mennyiségeket kifejezni nyilván ennek a tiszta komponensnek a hígítási sorát is meg kell mérni.

- Komplex oldatok kölcsönhatásainak vizsgálatakor figyelembe kell venni, hogy eleve egy több komponensü oldatból indulunk ki így a koncentráció változás önmagában is kölcsönhatás változást okozhat.

A kölcsönhatások vizsgálata a jövőben nagy valószínűséggel folytatódik, hiszen jelen munkámban csak néhány komponenst vizsgáltam meg. Ezen felül az alkalmazott módszer elemezni és validálni tudja az ember által érzékelt és az elektronikus nyelvvel mérhető kölcsönhatások átfedését, azonosságát.

Természetesen felvetődik a kérdés, hogy a dolgozatban bemutatott kölcsönhatások mennyire érintik a tanszéken korábban végzett kutatások hitelességét. Mivel korábbi eredményeink többnyire viszonylag hasonló minták (pl.: almalevek, kólák stb.) azonos koncentrációjú keverékei voltak vagy egykomponensü modell oldatok, így a fellépő 
kölcsönhatások többé kevésbé azonos mértékben érintették az összes vizsgált mintát és azok összehasonlíthatóak maradtak. Természetesen minden mérésünket a múltban is úgy végeztük, hogy a lehetséges zavaróhatásokat minimalizáljuk és ezért a gyártó ajánlásait figyelembe véve a mért minták koncentrációját 3 nagyságrenden belül tartottuk. 


\section{7. Új tudományos eredmények}

Az Alpha Astree elektronikus nyelv élelmiszerek mérésére specializált szenzorsorával végzett mérések eredményei alapján az alábbi új tudományos eredményeket fogalmaztam meg. Ezek az eredmények természetesen a kísérletekben használt müszerre/szenzorsorra és mintákra bizonyítottak teljes mértékben, azonban úgy gondolom, hogy eredményeim jelentősen hozzájárulnak az elektronikus nyelvről rendelkezésre álló ismereteinkhez. A dolgozat jelentőségét növeli egyrészt, hogy a vizsgált minták az élelmiszerek gyakori összetevői, másrészt a felderített kölcsönhatások lehetővé teszik az elektronikus nyelv mérési eredmények új szempontú elemzését.

1. A NaCl és a citromsav kevert oldataikban az emberi érzékelés számára releváns koncentráció tartományban az elektronikus nyelv szempontjából egymás hatását elfedö/kioltó kölcsönhatással rendelkeznek.

2. A NaCl és a Na-glutamát az emberi érzékelés számára releváns koncentráció tartományban az elektronikus nyelv szempontjából hasonlóan hatnak az érzékelőkre és ezért kevert oldataikban hatásuk képes, ha nem is lineárisan, összeadódni.

3. A koffein és a szacharóz elektronikus nyelv szenzorokra gyakorolt hatása függ a vizsgált oldatban található egyéb összetevőktől is, mivel ezen vegyületek mérési eredményeit a kölcsönhatások erőteljesen meghatározzák. A megfigyelt kölcsönhatások nem additív jellegüek és jelenlegi tudásunk szerint elöre nem jósolhatóak.

4. Az elektronikus nyelv szempontjából lehetséges ízfokozás és íz-maszkolás, azaz egy minta páros elektronikus nyelvvel mért különbségét valamilyen hozzáadott anyaggal (pl.: NaCl-dal) lehetséges megnövelni (pl.: almalevek esetében) vagy lecsökkenteni (pl.: citromsavval keverve a koffein vagy szacharóz hatását).

5. A mintában található anyagok interakciója koncentrációfüggő.

6. Egy minta elektronikus nyelvvel mért eredményeit befolyásolja a mérésben résztvevő többi minta is a folytonos kondicionálódás/drift által.

7. A méréseim során kidolgozott módszer alkalmazható az elektronikus nyelvet érintő kölcsönhatások vizsgálatára és elemzésére. A módszer legfontosabb elemei, hogy a vizsgált komponensek tisztán és kombinációban is jelen legyenek, kontroll minták alkalmazása, a korrekció, véletlenszerü minta sorrend és az eredmények szenzorokra lebontott és együttes elemzése. 


\section{A munka általánosíthatósága}

Ahogy az előző fejezetben kiemeltem megfigyeléseim teljes bizonyossággal csak a vizsgált rendszer esetében bizonyítottak. Ez természetesen felveti a kérdést, hogy más elektronikus nyelvek esetében is számíthatunk-e hasonló viselkedésre.

Pein és munkatársainak cikke [2015] hat elektronikus nyelvet hasonlít össze ugyan azt a minta együttest mérve minden müszerrel egy vakpróba során, azaz a mérés és kiértékelés alatt a minták összetétele nem volt ismert. A cikkben vizsgálták a müszerek eredményei közötti hasonlóságokat azt állapítva meg, hogy az egyes elektronikus nyelvek egymástól különbözö eredményeket produkálnak, az összehasonlításhoz mátrix korrelációs mérőszámokat használtak. Azonban a cikk ábráit megvizsgálva látható, hogy vannak hasonlóságok az egyes műszerek keverékekre való reagálásában. Ennek legmarkánsabb megnyilvánulása, hogy a citrát-iont tartalmazó és nem tartalmazó mintákat hasonlóan különbözteti meg az Astree (b) elektronikus nyelven kívül még két másik meglehetősen eltérő mérési elvü müszer is (c, e). A minták elrendezésének hasonlósága (5-ös és 7-es minták egymás közelében, de távol a többi mintától, 30. ábra) az összetevők közötti kölcsönhatásokra való hasonló reagálást jelzi, azaz különböző mérési elvű müszerek is hasonló eredményeket adhatnak.

A gyógyszeripari alkalmazásokban a kutatók sokszor abból indulnak ki, hogy a keserủ íz maszkolását az elektronikus nyelvvel sikerrel detektálják, tehát feltételezik, hogy az alkalmazott elektronikus nyelvek mindegyike képes a keserủ íz maszkolását érzékelni [Woertz és mtsai. 2011a]. A 3.4. fejezetben bemutatott íz maszkolási munkák mutatják, hogy ez lehetséges, tehát a müszerek közötti hasonlóság a kölcsönhatásokra vonatkozva is fenn áll. 
a)

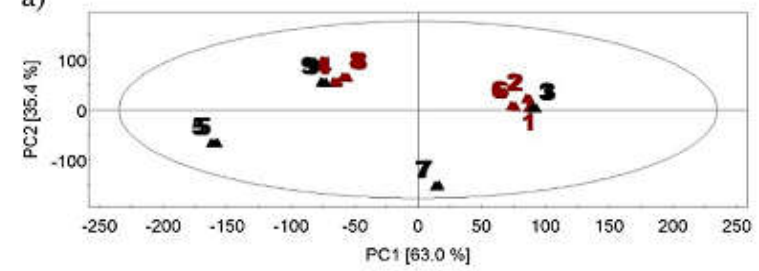

c)

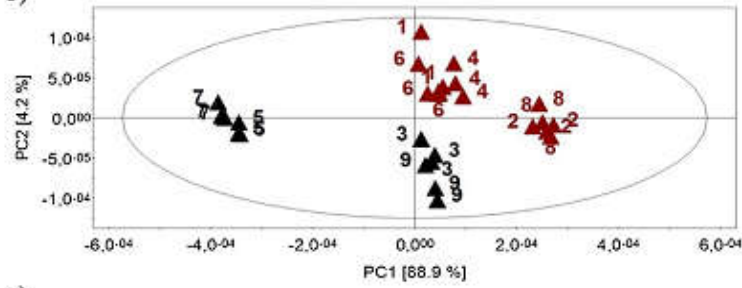

e)

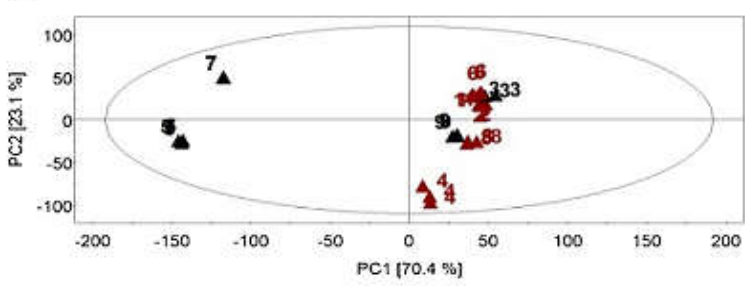

b)

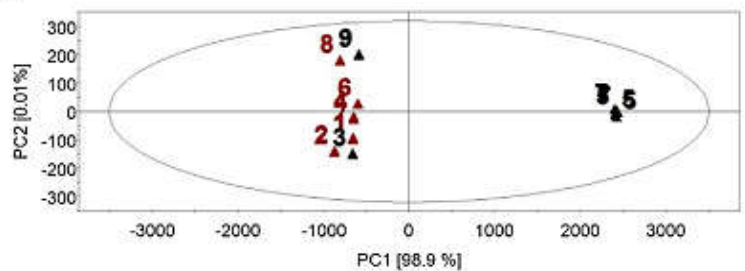

d)

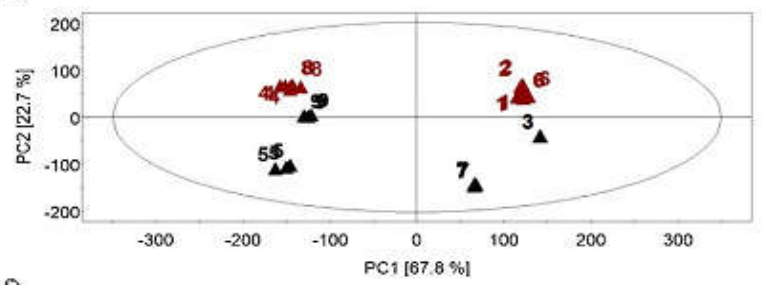

f)

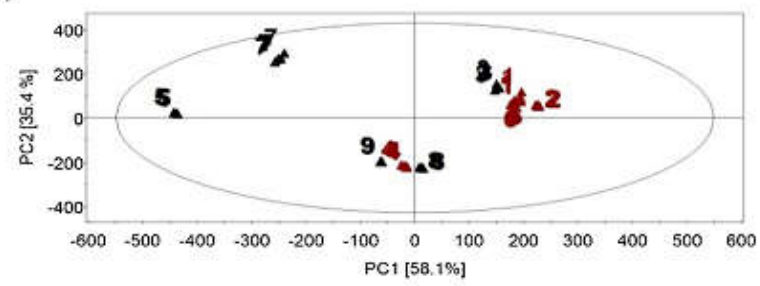

30. ábra Hat elektronikus nyelv összehasonlítása Pein és munkatárainak munkájából [2015]. a) Alpha Astree elektronikus nyelv (Francia) b) TS-5000Z elektronikus nyelv (Japán)

c) voltammetriás kísérleti elektronikus nyelv (Barcelona) d) potenciometriás kísérleti elektronikus nyelv (Varsó) e) potenciometriás átfolyó rendszerü kísérleti elektronikus nyelv (Varsó) f) potenciometriás kísérleti elektronikus nyelv (Szent-Pétervár). 


\section{A gyakorlatra vonatkozó javaslatok}

Munkámban felállított téziseknek gyakorlati vonzata is van.

1. A citromsav és a $\mathrm{NaCl}$ elektronikus nyelv esetében megfigyelt kölcsönhatását összevetve az emberi citromsav és $\mathrm{NaCl}$ érzékeléssel [Breslin 1996, Keast és mtsai. 2003] azt láthatjuk, hogy az emberi íz-küszöb érték közelében az ember számára a két összetevő fokozza egymás hatását, míg magas koncentrációk alkalmazása esetén a $\mathrm{NaCl}$ és citromsav kölcsönösen csökkenti egymás hatását. Méréseinkben végig az emberi íz-küszöb értékeket (2. táblázat) legalább két nagyságrenddel meghaladó koncentrációkkal dolgoztam, így az utóbbi tartomány az érdekes. A kölcsönhatás hasonlósága az emberi érzékelés és az elektronikus nyelv mérés esetében citromsav és $\mathrm{NaCl}$ viszonylatában megerősíti, hogy a müszer alkalmas íz vizsgálatokra.

2. A NaCl és a Na-glutamát kölcsönhatása is hasonló az emberi ízérzékelés esetében, mint amit az elektronikus nyelv mérésekben megfigyeltem, azaz összeadódó jellegü [Keast és mtsai. 2003]. Ez újabb bizonyíték arra, hogy az Alpha Astree elektronikus nyelv mérési eredményei vonatkoztathatóak az emberi érzékszervi elemzésekre.

3. A koffein és szacharózra vonatkozó eredmények következménye, hogy különös gonddal kell ezen vegyületeket is tartalmazó minták elemzését elvégezni. A leggyakrabban használt többváltozós elemzésekben a lényeges különbségek 'megbújhatnak' a magasabb sorszámú látens változókban, melyeket gyakran elhanyagolnak. A koffein és a szacharóz interakciói nem tendenciózusak ezért előre nem megjósolhatóak. Emiatt egy eddig nem vizsgált keverék elektronikus nyelvvel mért eredményei sem becsülhetőek előre megbízhatóan.

4. Ha két komponens közül az egyik képes elfedni egy másik keltette szenzorjelet, akkor az elfedett komponens az elektronikus nyelv szempontjából nem mérhetővé válik. Ez korlátot jelent és így bizonyos oldatok esetében az elektronikus nyelv nem képes megbízható választ adni, mint ahogy a koffein és a szacharóz hatása nem volt mérhető, mikor az oldatban citromsav és $\mathrm{NaCl}$ is egyszerre volt jelen.

Az ízfokozás jelenségét ki lehet használni és segítségével az elektronikus nyelvvel végzett mérésekben még több információhoz juthatunk, például a $\mathrm{NaCl}$-dal kiegészített almalevek esetében a megkülönböztethetetlennek tünő minták különbségeit felerősíthettem a megfelelő 'kontraszt' komponens hozzáadásával. 
5. A mért oldatok koncentrációjának változása befolyásolja a kialakuló kölcsönhatásokat is. Éppen ezért a vizsgálatokban (ha nem éppen a koncentráció függést vizsgálunk), érdemes egy viszonylag szük koncentráció tartományban maradni. Az elektronikus nyelvet gyártó Alpha M.O.S. javaslata szerint tanácsos a leginkább eltérő koncentrációkat is három nagyságrenden belül tartani az esetleges mérés közben fellépő zavaróhatások minimalizálására. Azonban az eredményeim megmutatták, hogy akár tízszeres hígítás is jelentős változásokat okozhat. A koncentráció változás okozta kölcsönhatás változást és ezáltal elektronikus nyelv szenzorjel változást ki is lehet használni. Olyan minta oldatok esetében ahol a koncentráció meghatározása a cél és ismert, hogy az adott minta típus (például szója ital) rendelkezik egyes szenzorokra adott koncentrációban szélső értékekkel (GA; $1 \mathrm{~mL} / \mathrm{L})$, úgy a mintákat erre a koncentrációra hozzávetőlegesen beállítva a diszkriminációt megkönnyítjük, mivel a szélsőérték környékén kis koncentráció változás is nagy szenzorjel változást okoz.

6. Mivel a mérésben résztvevő minták a mérés közben folytatódó kondicionálódás következtében képesek egymással kölcsönhatásba lépni anélkül is, hogy összekevernénk őket, fontos a mérési szekvencia gondos összeállítása. Ennek akkor van igazán nagy jelentősége, ha a vizsgált minták nem mérhetőek le egyetlen mérési alkalommal. Ekkor érdemes az egyes szekvenciákat kiegyensúlyozottan kialakítani, azaz minden mérési alkalommal egyenletesen osszuk el a különböző karakterü (sós, savanyú, édes) mintákat. Ebben az esetben különösen fontos kontroll minták használata minden mérési alkalommal.

7. A kölcsönhatások vizsgálatára kifejlesztett módszer lehetővé teszi, hogy a további kölcsönhatásokat megcélzó méréseket már kiforrott méréstechnikával és feldolgozási algoritmusokkal hajtsuk végre a jövőben. 


\section{0. Összefoglalás}

Az elektronikus nyelv alapvető koncepciója, hogy a vizsgált mintákról nem összetételszerü információt ad, hanem egy olyan jelmintázatot, ami mint egy ujjlenyomat jellemzi a vizsgált oldatot. Ezek után ez az ujjlenyomat összehasonlíthatóvá vagy éppen megkülönböztethetővé teszi a vizsgált mintákat. Megfelelő kalibráció és statisztikai módszerek alkalmazásával akár elvont dolgok, mint a fogyasztói kedveltség is becsülhető az elektronikus nyelv mérési eredményei alapján. Az elektronikus nyelv lehetséges alkalmazásai a tudományos kutatás fókuszában áll, hisz napról napra jelennek meg új cikkek a témával kapcsolatban mind az élelmiszeripar mind a gyógyszeripar területéről.

Az elektronikus nyelv fejlesztése során két alapvető irányvonal rajzolódott ki. Az egyik célja, hogy a lehető legérzékenyebb müszert hozza létre és ezt nevezik szorosabb értelemben elektronikus nyelvnek (electronic tongue). A másik fejlesztési cél, hogy egy az emberi íz érzékelést a lehető legjobban utánzó berendezést hozzanak létre, melyet íz elemzőnek kereszteltek el (taste analyzer). Ez utóbbinak része, hogy az ember számára jól ismert íz kölcsönhatásokra (pl.: a konyhasó fokozza az ízeket) a műszer is hasonlóan reagáljon. Ráadásul méréstechnikai szempontból is fontos, hogy a mért mintákban található összetevők közötti, szenzorjeleket meghatározó kölcsönhatásokat részleteiben is ismerjük, mivel mérést korlátozó vagy éppen kiterjesztő hatása lehet. Mivel az elektronikus nyelvvel mért minták szinte mindig egynél több oldott komponenst tartalmaznak, magától értetődik a kölcsönhatások gyakori és meghatározó jelenléte.

Ennek fényében különösen érdekes, hogy a tudományos irodalomban a témával csak igen korlátozottan foglakoznak, szinte kizárólag keserü ízű vegyületek kölcsönhatását vizsgálták más anyagokkal, melyek többnyire édesek voltak. Ráadásul az esetek nagy részében az elektronikus nyelv csak, mint keserü-detektor volt jelen a mérésekben és a kölcsönhatások természetét nem vizsgálták.

Munkánkban az Alpha Astree potenciometriás elektronikus nyelv mérési eredményeit befolyásoló ízzel rendelkező vegyületek közötti kölcsönhatásokat igyekeztünk felderíteni a hatások globális és szenzor szintű elemzésével. A kapott eredmények mind elméleti mind gyakorlati szempontból jelentősen hozzá járulnak a technikáról szerzett tudásunkhoz.

Méréseinkben a kölcsönhatások vizsgálatához az öt (szabványosnak tekinthető) alapíznek megfelelő vegyületből készített tiszta és kombinált oldatokat és élelmiszer mintákat vizsgáltam egy az ismert zavaró hatásokat minimalizáló mérési módszerrel. A mérési 
eredményeket mind szenzoronként, mind a technikában bevettnek számító többváltozós módszerekkel kiértékeltük, hogy az interakciók hatását több szinten is megvizsgáljuk.

Méréseink és elemzéseink során azt figyeltük meg, hogy a $\mathrm{NaCl}$ és a citromsav kevert oldataikban az elektronikus nyelv szempontjából egymás hatását elfedö/kioltó kölcsönhatással rendelkeznek, mely a vizsgált koncentráció tartományban megegyezik az emberi érzékeléssel.

A $\mathrm{NaCl}$ és a Na-glutamát kölcsönhatását vizsgálva azt találtuk, hogy az elektronikus nyelv szempontjából hasonlóan hatnak az érzékelőkre és ezért kevert oldataikban hatásuk képes, ha nem is lineárisan, összeadódni és ez megint csak hasonlóságot jelent az emberi ízérzékeléssel.

Koffein és a szacharóz oldatok esetében a vegyületek hatása az elektronikus nyelv érzékelőkre függ, az egyéb oldat összetevőktöl is. A kölcsönhatás nem additív jellegü és jelenleg elöre nem jósolható.

Méréseink igazolták, hogy az elektronikus nyelv szempontjából lehetséges ízfokozás és íz-maszkolás, azaz egy minta páros elektronikus nyelvvel mért különbségét valamilyen hozzáadott anyaggal (pl.: NaCl-dal almalevek esetében) lehetséges megnövelni vagy lecsökkenteni (pl.: citromsavval keverve a koffein vagy szacharóz hatását).

Munkánkban arra is találtam bizonyítékot, hogy a mintában található anyagok interakciója koncentrációfüggő, mely egyrészt korlátozhatja az egy mérésben jelenlévő minták koncentráció tartományát, de kihasználható kis koncentráció különbségek kimutatására.

Méréseink azt is megmutatták, hogy egy minta elektronikus nyelvvel mért eredményeit befolyásolja a mérésben résztvevő többi minta is.

Ahhoz, hogy a fenti eredményekhez eljussunk természetesen szükség volt egy mérési metodika kidolgozására, mely alkalmasnak bizonyult a kölcsönhatások detektálására. 


\section{Referenciák}

AlphaM.O.S. "T-SAS-02 Electronic Tongue Sensors Detection Thresholds." In Alpha Astree Technical note. Toulouse: Alpha M.O.S., 2002a.

AlphaM.O.S. "T-SAS-04 Astree Electrochemical Sensor Technology." In Alpha Astree Technical note. Toulouse: Alpha M.O.S., 2002b.

AlphaM.O.S. "Alpha Astree electronic tongue user manual." Toulouse: Alpha M.O.S., 2003.

AlphaM.O.S. "Calibration Set Parameters: Standard, Long Term, Trouble-shooting." In Alpha Astree Technical note. Toulouse: Alpha M.O.S. , 2006.

Artursson T., Eklov T., Lundstrom I., Martensson P., Sjostrom M., Holmberg M. (2000): Drift correction for gas sensors using multivariate methods. Journal of Chemometrics, 14(5-6), 711-723. Doi 10.1002/1099-128x(200009/12)14:5/6<711::AidCem607>3.0.Co;2-4

Bergveld P. (1970): Development of an ion-sensitive solid-state device for neurophysiological measurements. IEEE Trans Biomed Eng., 17(1), 70-71.

Bergveld P. (2003): Thirty years of ISFETOLOGY: What happened in the past 30 years and what may happen in the next 30 years. Sensors and Actuators B: Chemical, 88(1), 120. http://dx.doi.org/10.1016/S0925-4005(02)00301-5

Bratov A., Abramova N., Ipatov A. (2010): Recent trends in potentiometric sensor arrays-A review. Analytica Chimica Acta, 678(2), 149-159. DOI 10.1016/j.aca.2010.08.035

Brereton R. G. "Linear Discriminant Analysis." Chemometrics for Pattern Recognition, 328330: John Wiley \& Sons, Ltd, 2009.

Breslin P. A. S. (1996): Interactions among salty, sour and bitter compounds. Trends in Food Science \& Technology, 7(12), 390-399. Doi 10.1016/S0924-2244(96)10039-X

Campbell G. A., Charles J. A., Roberts-Skilton K., Tsundupalli M., Oh C. K., Weinecke A., Wagner R., Franz D. (2012): Evaluating the taste masking effectiveness of various flavors in a stable formulated pediatric suspension and solution using the Astree (TM) electronic tongue. Powder Technology, 224, 109-123. DOI 10.1016/j.powtec.2012.02.038

Choi D. H., Kim N. A., Nam T. S., Lee S., Jeong S. H. (2014): Evaluation of taste-masking effects of pharmaceutical sweeteners with an electronic tongue system. Drug Development and Industrial Pharmacy, 40(3), 308-317. Doi $10.3109 / 03639045.2012 .758636$ 
Cole M., Spulber I., Gardner J. W. (2015): Surface acoustic wave electronic tongue for robust analysis of sensory components. Sensors and Actuators B-Chemical, 207, 1147-1153. DOI 10.1016/j.snb.2014.09.029

Delwiche J. (1996): Are there 'basic' tastes? Trends in Food Science \& Technology, 7, 411 415.

Di Natale C., D'Amico A., Vlasov Y., Legin A. V., Rudnitskaya A. M. (1995): Multicomponent analysis of heavy metal cations and inorganic anions in liquids by a non-selective chalcogenide glass sensor array. 512. p. In: (Szerk.): International Conference on Solid-State Sensors and Actuators and Eurosensors IX. Stockholm, Sweden: IEEE, $\mathrm{p}$.

Di Natale C., Davide F, Amico AD, Legin A, Rudinitskaya A, Selezenev BL, Y. V. (1996): Applications of an electronic tongue to the environmental control. 1345-1348. p. In: (Szerk.): Technical digest of Eurosensors X. Leuven, Belgium: $\mathrm{p}$.

Di Natale C., Macagnano A., Davide F., D'Amico A., Legin A., Vlasov Y., Rudnitskaya A., Selezenev B. (1997): Multicomponent analysis on polluted waters by means of an electronic tongue. Sensors and Actuators, B: Chemical, 44(1-3), 423-428.

Erickson R. P. (2008): A study of the science of taste: On the origins and influence of the core ideas. Behavioral and Brain Sciences, 31(1), 59-75.

Esbensen K., Kirsanov D., Legin A., Rudnitskaya A., Mortensen J., Pedersen J., Vognsen L., Makarychev-Mikhailov S., Vlasov Y. (2004): Fermentation monitoring using multisensor systems: feasibility study of the electronic tongue. Analytical and Bioanalytical Chemistry, 378(2), 391-395. DOI 10.1007/s00216-003-2299-x

Escuder-Gilabert L., Peris M. (2010): Review: Highlights in recent applications of electronic tongues in food analysis. Analytica Chimica Acta, 665(1), 15-25. 10.1016/j.aca.2010.03.017

Grimnes S., Martinsen Ø. G. "BIOIMPEDANCE AND BIOELECTRICITY BASICS." Great Britain: Academic Press, 2008.

Guhmann M., Preis M., Gerber F., Pollinger N., Breitkreutz J., Weitschies W. (2015): Design, development and in-vitro evaluation of diclofenac taste-masked orodispersible tablet formulations. Drug Development and Industrial Pharmacy, 41(4), 540-551. Doi $10.3109 / 03639045.2014 .884122$

Haraguchi T., Yoshida M., Uchida T. (2014): Evaluation of ebastine-loaded orally disintegrating tablets using new apparatus of detecting disintegration time and etongue system. Journal of Drug Delivery Science and Technology, 24(6), 684-688. 
Hayashi K., Yamanaka M., Toko K., Yamafuji K. (1990): Multichannel taste sensor using lipid membranes. Sensors and Actuators: B. Chemical, 2(3), 205-213.

Henning H. (1916): Die qualitatenreihe des geschmaks. Zeitschrift für Psychologie, 74, 203219.

Holmin S., Krantz-Rülcker C., Lundström I., Winquist F. (2001): Drift correction of electronic tongue responses. Measurement Science and Technology, 12(8), 1348-1354.

ISO/FIDS_3972:2011. "Sensory analysis — Methodology — Method of investigating sensitivity of taste." edited by Organisation I. S.: 3972, 2011.

Ito M., Ikehama K., Yoshida K., Haraguchi T., Yoshida M., Wada K., Uchida T. (2013): Bitterness prediction of $\mathrm{H}-1$-antihistamines and prediction of masking effects of artificial sweeteners using an electronic tongue. International Journal of Pharmaceutics, 441(1-2), 121-127. DOI 10.1016/j.ijpharm.2012.11.047

Keast S. J. R., Breslin P. A. S. (2003): An overview of binary taste-taste interactions. Food Quality and Preference, 14(2), 111-124.

Kinnamon S. C., Cummings T. A. (1992): Chemosensory transduction mechanisms in taste. Annu Rev Physiol, 54, 715-731. 10.1146/annurev.ph.54.030192.003435

Kobayashi Y., Habara M., Ikezazki H., Chen R. G., Naito Y., Toko K. (2010): Advanced Taste Sensors Based on Artificial Lipids with Global Selectivity to Basic Taste Qualities and High Correlation to Sensory Scores. Sensors, 10(4), 3411-3443. Doi $10.3390 / \mathrm{S} 100403411$

Kovács Z. "Elektronikus nyelv alkalmazása instant italok vizsgálatára, Diploma munka." Budapesti Corvinus Egyetem, 2007.

Kovács Z. "Módszerek elektronikus nyelvvel végzett méréseknél fellépő zavaró hatások csökkentésére." Budapesti Corvinus egyetem, 2012.

Kovács Z., Dalmadi I., Lukács L., László S., Szántai-Kőhegyi K., Kókai Z., Fekete A. (2010): Geographical origin identification of pure Sri Lanka tea infusions with electronic nose, electronic tongue and sensory profile analysis. Journal of Chemometrics, 24(3-4), 121-130.

Kovács Z., Sipos L., Szöllősi D., Kókai Z., Székely G., Fekete A. (2011): Electronic tongue and sensory evaluation for sensing apple juice taste attributes. Sensor Letters, 9(4), 1273-1281.

Kovács Z., Szöllősi D., Fekete A. (2009): Application of electronic tongue to soya drink discrimination. Progress in Agricultural Engineering Sciences, 5(1), 75-96.

Lawless H. T., Heymann H. "Sensory evaluation of food." In Food Science Text Series, edited by Heldman D. R. New York Dordrecht Heidelberg London: Springer, 2010. 
Legin A., Rudnitskaya A., Kirsanov D., Frolova Y., Clapham D., Caricofe R. (2009): Assessment of bitterness intensity and suppression effects using an Electronic Tongue. Olfaction and Electronic Nose, Proceedings, 1137, 271-274.

Magnuson B. A., Burdock G. A., Doull J., Kroes R. M., Marsh G. M., Pariza M. W., Spencer P. S., Waddell W. J., Walker R., Williams G. M. (2007): Aspartame: a safety evaluation based on current use levels, regulations, and toxicological and epidemiological studies. Crit Rev Toxicol, 37(8), 629-727. $10.1080 / 10408440701516184$

Magyar_Élelmiszerkönyv_Bizottság. "1-2-95/2 számú előírás." In MAGYAR ÉLELMISZERKÖNYV, 2000.

Maniruzzaman M., Douroumis D. (2015): An in-vitro-in-vivo taste assessment of bitter drug: comparative electronic tongues study. Journal of Pharmacy and Pharmacology, 67(1), 43-55. Doi 10.1111/Jphp.12319

Mennella J. A., Spector A. C., Reed D. R., Coldwell S. E. (2013): The Bad Taste of Medicines: Overview of Basic Research on Bitter Taste. Clinical Therapeutics, 35(8), 1225-1246. DOI 10.1016/j.clinthera.2013.06.007

Mojet J., Christ-Hazelhof E., Heidema J. (2005): Taste perception with age: pleasantness and its relationships with threshold sensitivity and supra-threshold intensity of five taste qualities. Food Quality and Preference, 16(5), 413-423. 10.1016/j.foodqual.2004.08.001

Monteagudo E., Langenheim M., Salerno C., Buontempo F., Bregni C., Carlucci A. (2014): Pharmaceutical optimization of lipid-based dosage forms for the improvement of taste-masking, chemical stability and solubilizing capacity of phenobarbital. Drug Development and Industrial Pharmacy, 40(6), 783-792. Doi $10.3109 / 03639045.2013 .787536$

Næs T., Isaksson T., Fearn T., Davies T. "A User-Friendly Guide to Multivariate Calibration and Classification." Chichester, UK: NIR Publications, 2002.

Nagamori T., Toko K., Kikkawa Y., Watanabe T., Endou K. (1999): Detection of the suppression of saltiness by Umami substances using a taste sensor. Sensors and Materials, 11(8), 469-477.

Newman J., O'Riordan D., Jacquier J. C., O'Sullivan M. (2015): Masking of bitterness in dairy protein hydrolysates: Comparison of an electronic tongue and a trained sensory panel as means of directing the masking strategy. Lwt-Food Science and Technology, 63(1), 751-757. DOI 10.1016/j.lwt.2015.03.019 
Pein M., Kirsanov D., Ciosek P., del Valle M., Yaroshenko I., Wesoły M., Zabadaj M., Gonzalez-Calabuig A., Wróblewski W., Legin A. (2015): Independent comparison study of six different electronic tongues applied for pharmaceutical analysis. Journal of Pharmaceutical and Biomedical Analysis, 114, 321-329. http://dx.doi.org/10.1016/j.jpba.2015.05.026

Persaud K., Dodd G. (1982): Analysis of discrimination mechanisms in the mammalian olfactory system using a model nose. Nature, 299(5881), 352-355.

Pourciel-Gouzy M. L., Assie-Souleille S., Mazenq L., Launay J., Temple-Boyer P. (2008): $\mathrm{pH}$-ChemFET-based analysis devices for the bacterial activity monitoring. Sensors and Actuators B-Chemical, 134(1), 339-344. DOI 10.1016/j.snb.2008.04.029

Preis M., Eckert C., Hausler O., Breitkreutz J. (2014): A comparative study on solubilizing and taste-masking capacities of hydroxypropyl-beta-cyclodextrin and maltodextrins with high amylose content. Sensors and Actuators B-Chemical, 193, 442-450. DOI 10.1016/j.snb.2013.12.005

R Development Core Team. "R: A Language and Environment for Statistical Computing. R Foundation for Statistical Computing." Vienna, 2012.

Riul A., Malmegrim R. R., Fonseca F. J., Mattoso L. H. C. (2003): An artificial taste sensor based on conducting polymers. Biosensors \& Bioelectronics, 18(11), 1365-1369. Doi 10.1016/S0956-5663(03)00069-1

Soderstrom C., Rudnitskaya A., Legin A., Krantz-Rulcker C. (2005): Differentiation of four Aspergillus species and one Zygosaccharomyces with two electronic tongues based on different measurement techniques. Journal of Biotechnology, 119(3), 300-308. DOI 10.1016/j.jbiotec.2005.04.017

Soderstrom C., Winquist F., Krantz-Rulcker C. (2003): Recognition of six microbial species with an electronic tongue. Sensors and Actuators B-Chemical, 89(3), 248-255. Doi $10.1016 / \mathrm{S} 0925-4005(02) 00474-4$

Szöllősi D., Dénes D. L., Firtha F., Kovács Z., Fekete A. (2012): Comparison of six multiclass classifiers by the use of different classification performance indicators. Journal of Chemometrics, 26, 76-84. 10.1002/cem.1391

Szöllősi D., Kovács Z., Várvölgyi E., Fekete A. "The Effect of Glucose on Electronic Taste Analyzer." In ASABE 2013 Annual International Meeting. Kansas City, Missouri: American Society of Agricultural and Biological Engineers, 2013.

Tahara Y., Toko K. (2013): Electronic Tongues-A Review. Ieee Sensors Journal, 13(8), 3001-3011. Doi 10.1109/Jsen.2013.2263125 
Tahara Y., Toko K. (2013): Electronic Tongues-A Review. Ieee Sensors Journal, 13(8), 3001-3011. 10.1109/JSEN.2013.2263125

Toko K. (1996): Taste sensor with global selectivity. Materials Science and Engineering C, $4(2), 69-82$.

Turner C., Rudnitskaya A., Legin A. (2003): Monitoring batch fermentations with an electronic tongue. Journal of Biotechnology, 103(1), 87-91. Doi 10.1016/S01681656(03)00066-X

Vlasov Y., Legin A., Rudnitskaya A., Di Natale C., D'Amico A. (2005): Nonspecific sensor arrays ("electronic tongue") for chemical analysis of liquids (IUPAC Technical Report). Pure and Applied Chemistry, 77(11), 1965-1983. 10.1351/pac200577111965

Vlasov Y. G., Legin A., Rudnitskaya A. (2002): Electronic tongues and their analytical application. Analytical and Bioanalytical Chemistry, 373(3), 136-146. $10.1007 / \mathrm{s} 00216-002-1310-2$

Vlasov Y. G., Legin A. V., Rudnitskaya A. M. (1997): Cross-sensitivity evaluation of chemical sensors for electronic tongue: Determination of heavy metal ions. Sensors and Actuators, B: Chemical, 44(1-3), 532-537.

Vojinovic V., Cabral J. M. S., Fonseca L. P. (2006): Real-time bioprocess monitoring Part I: In situ sensors. Sensors and Actuators B-Chemical, 114(2), 1083-1091. DOI 10.1016/j.snb.2005.07.059

Wei Y. J., Nedley M. P., Bhaduri S. B., Bredzinski X., Boddu S. H. S. (2015): Masking the Bitter Taste of Injectable Lidocaine $\mathrm{HCl}$ Formulation for Dental Procedures. Aaps Pharmscitech, 16(2), 455-465. DOI 10.1208/s12249-014-0239-z

Winquist F. (2008): Voltammetric electronic tongues - basic principles and applications. Microchimica Acta, 163(1-2), 3-10. DOI 10.1007/s00604-007-0929-2

Winquist F., Krantz-Rülcker C., Lundström I. (2004): Electronic tongues. Mrs Bulletin, 29(10), 726-731.

Woertz K., Tissen C., Kleinebudde P., Breitkreutz J. (2011a): Development of a TasteMasked Generic Ibuprofen Suspension: Top-Down Approach Guided by Electronic Tongue Measurements. Journal of Pharmaceutical Sciences, 100(10), 4460-4470. Doi $10.1002 / J p s .22629$

Woertz K., Tissen C., Kleinebudde P., Breitkreutz J. (2011b): Taste sensing systems (electronic tongues) for pharmaceutical applications. International Journal of Pharmaceutics, 417(1-2), 256-271. 
Wu C. S., Du L. P., Zou L., Zhao L. H., Huang L. Q., Wang P. (2014): Recent advances in taste cell- and receptor-based biosensors. Sensors and Actuators B-Chemical, 201, 7585. DOI 10.1016/j.snb.2014.04.021

Xiao W. X., Chen Z. C., Jiang X. G., Zhao H. T., Chu F. G., Hou H. B. (2012): A taste sensor based on surface imprinted $\mathrm{TiO} 2$ membrane. Tenth International Conference on Photonics and Imaging in Biology and Medicine (Pibm 2011), 8329. Doi $10.1117 / 12.922998$

Yasuura M., Okazaki H., Tahara Y., Ikezaki H., Toko K. (2014): Development of sweetness sensor with selectivity to negatively charged high-potency sweeteners. Sensors and Actuators B: Chemical, 201, 329-335. http://dx.doi.org/10.1016/j.snb.2014.04.087

Yasuura M., Tahara Y., Ikezaki H., Toko K. (2014): Development of a Sweetness Sensor for Aspartame, a Positively Charged High-Potency Sweetener. Sensors, 14(4), 7359-7373. Doi 10.3390/S140407359

Yi E. J., Kim J. Y., Rhee Y. S., Kim S. H., Lee H. J., Park C. W., Park E. S. (2014): Preparation of sildenafil citrate microcapsules and in vitro/in vivo evaluation of taste masking efficiency. International Journal of Pharmaceutics, 466(1-2), 286-295. DOI 10.1016/j.ijpharm.2014.03.001

Zakaria N. Z. I., Masnan M. J., Zakaria A., Shakaff A. Y. M. (2014): A Bio-Inspired Herbal Tea Flavour Assessment Technique. Sensors, 14(7), 12233-12255. Doi $10.3390 /$ S140712233 


\section{Melléklet - A dolgozat fơrészéböl kimaradt ábrák}

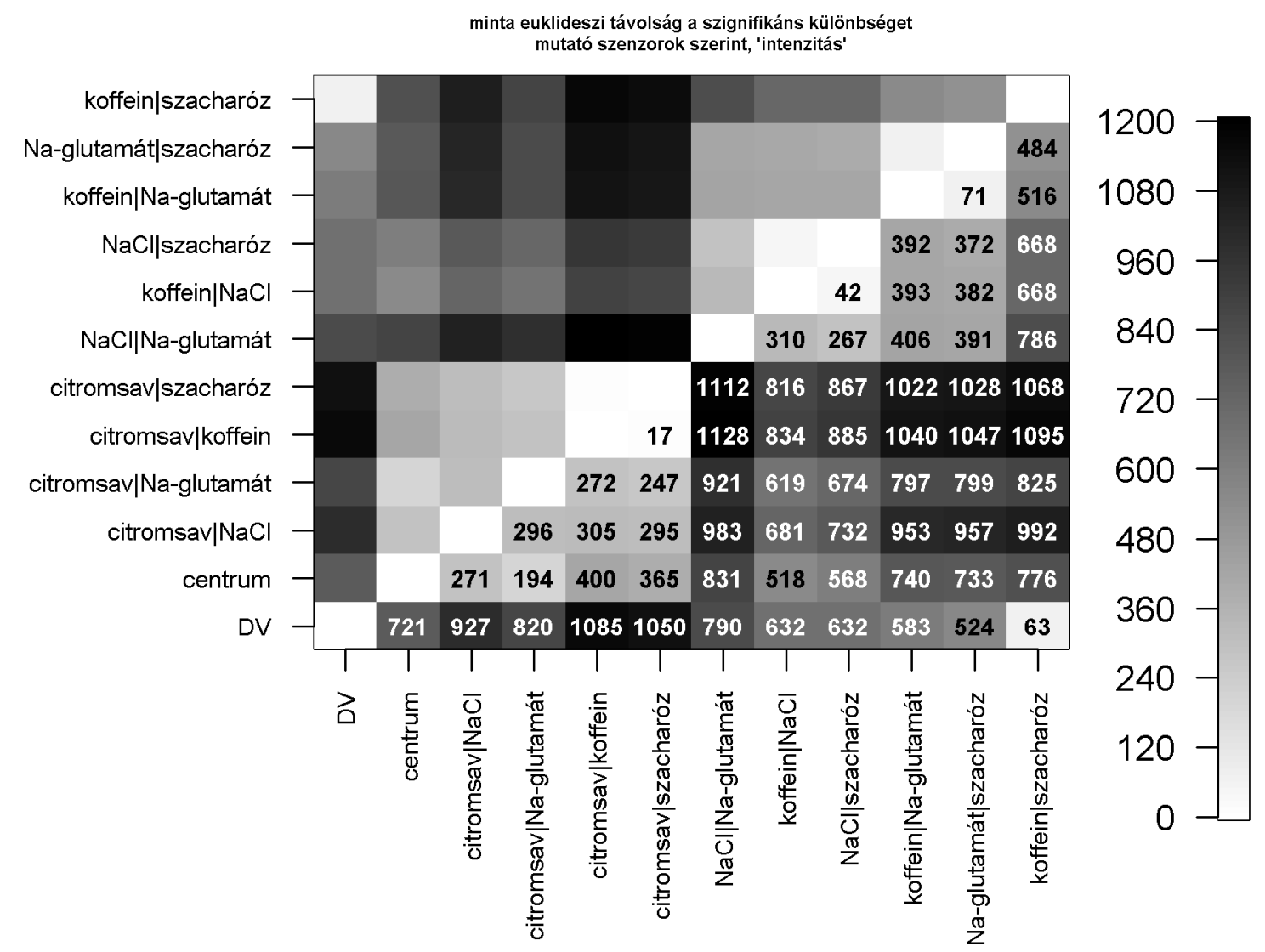

Melléklet 1. ábra Egy és kétkomponensü modell oldatok páronkénti t-próbája és átlagos euklideszi távolságuk a szignifikáns különbséget adó szenzorok által kifeszített térben. A fehér mezők a különbség nem szignifikáns voltát jelentik. 


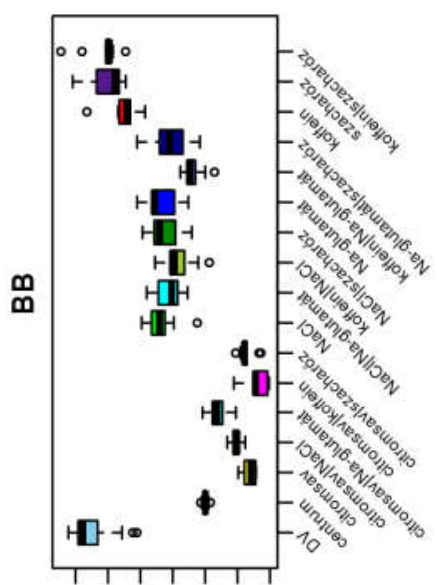

웅음융우웅 웅
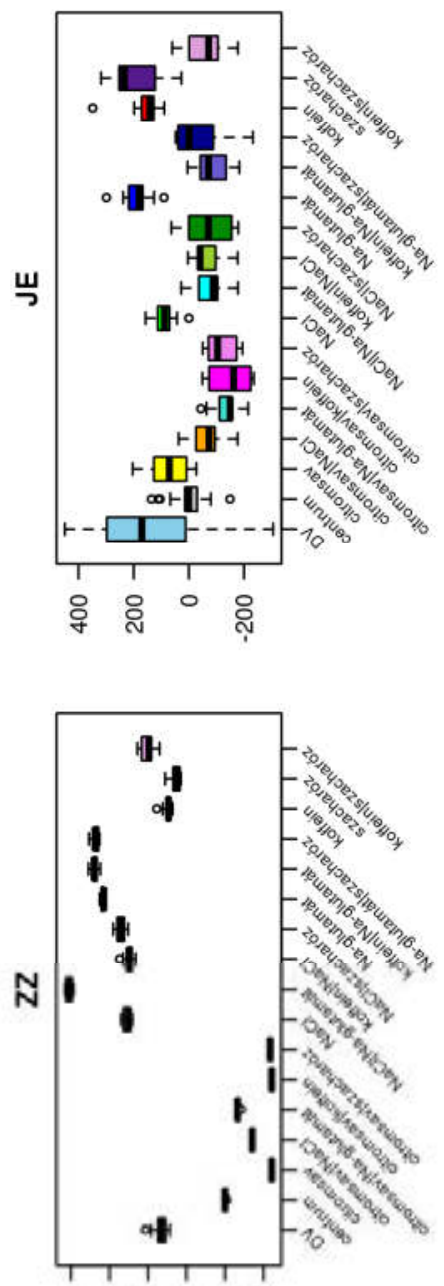

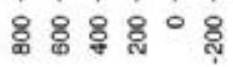

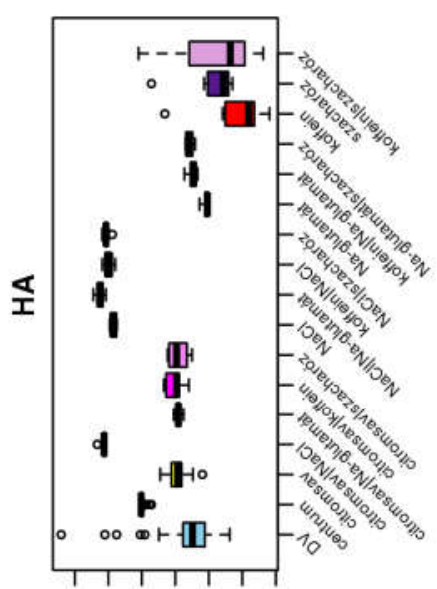

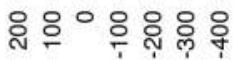
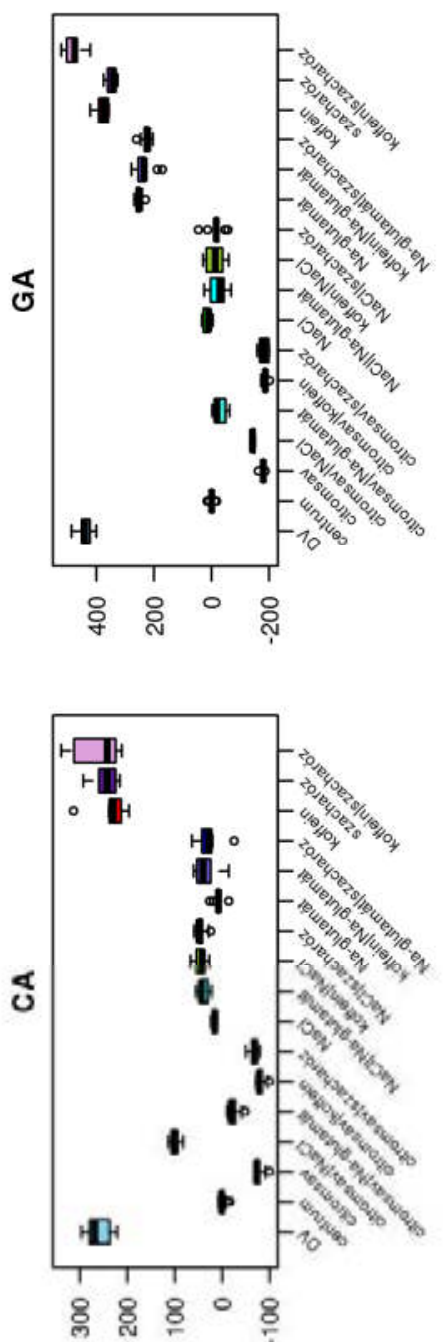

Melléklet 2. ábra Egy- és kétkomponensü modell oldatok szenzorainak boxplot ábrája. 


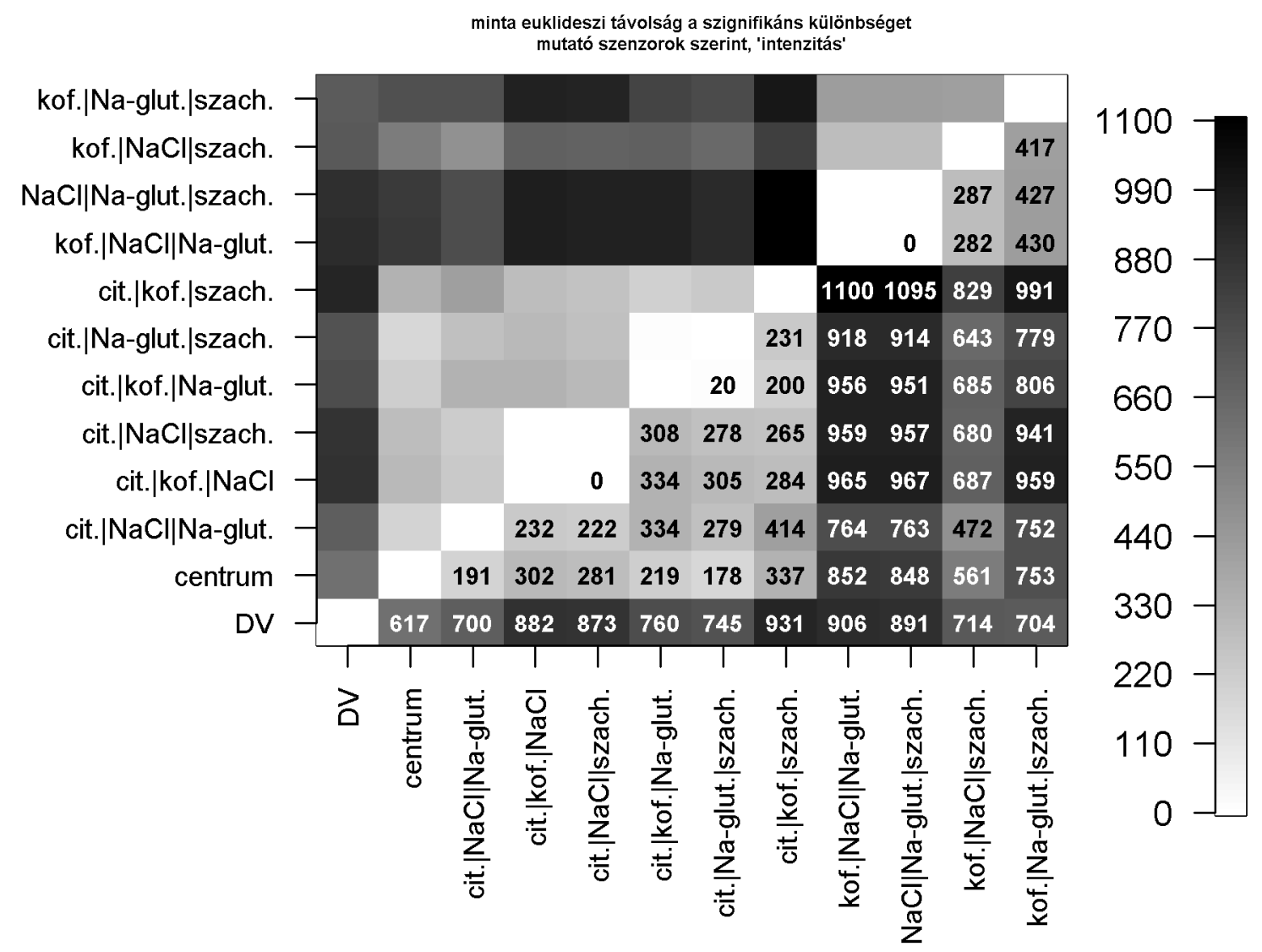

Melléklet 3. ábra A három komponensü modell oldatok páronkénti t-próbája és átlagos euklideszi távolságuk a szignifikáns különbséget adó szenzorok által kifeszített térben. A fehér mezők a különbség nem szignifikáns voltát jelentik. 

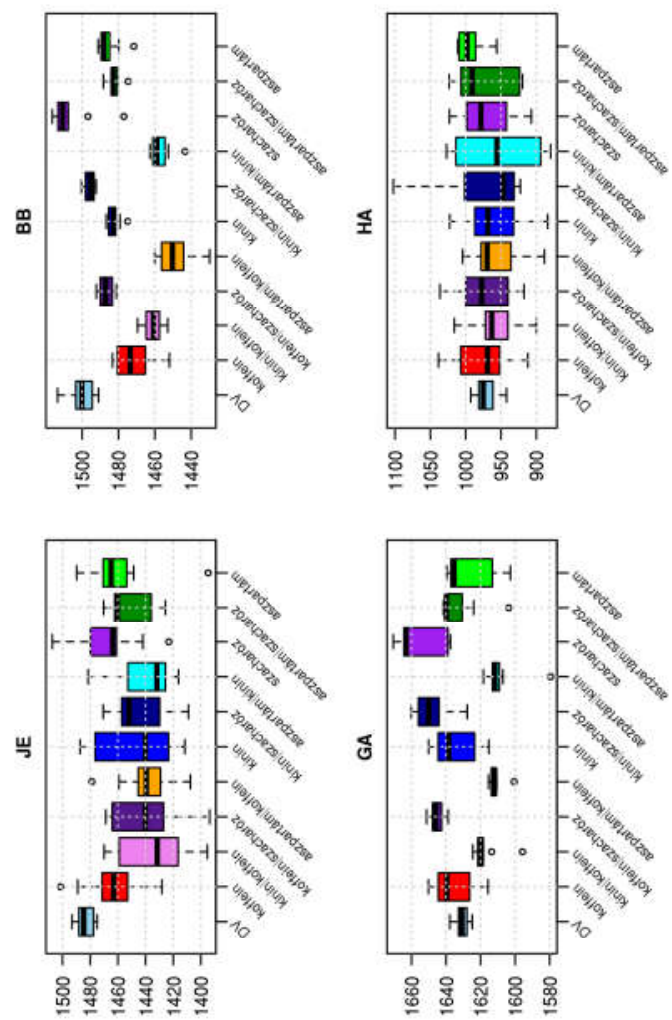

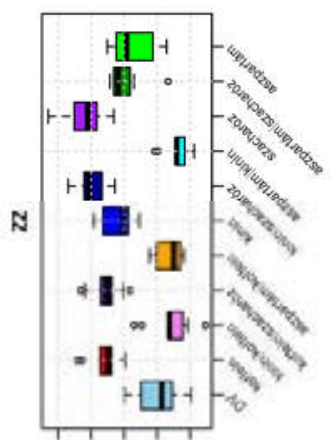

总总욤원

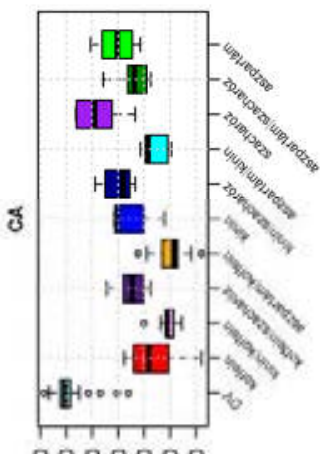

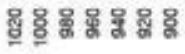

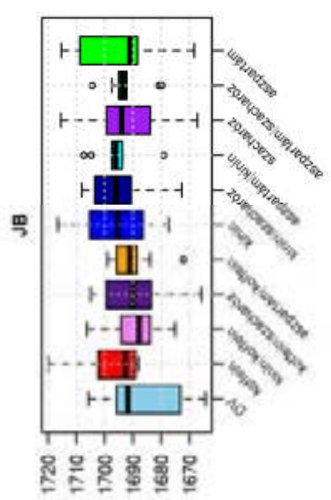

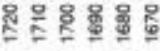

Melléklet 4. ábra Koffein, szacharóz, kinin és aszpartám minták tiszta és kettős kombinációinak elektronikus nyelvvel mért jeleinek boxplot ábrája szenzorokra lebontva. 


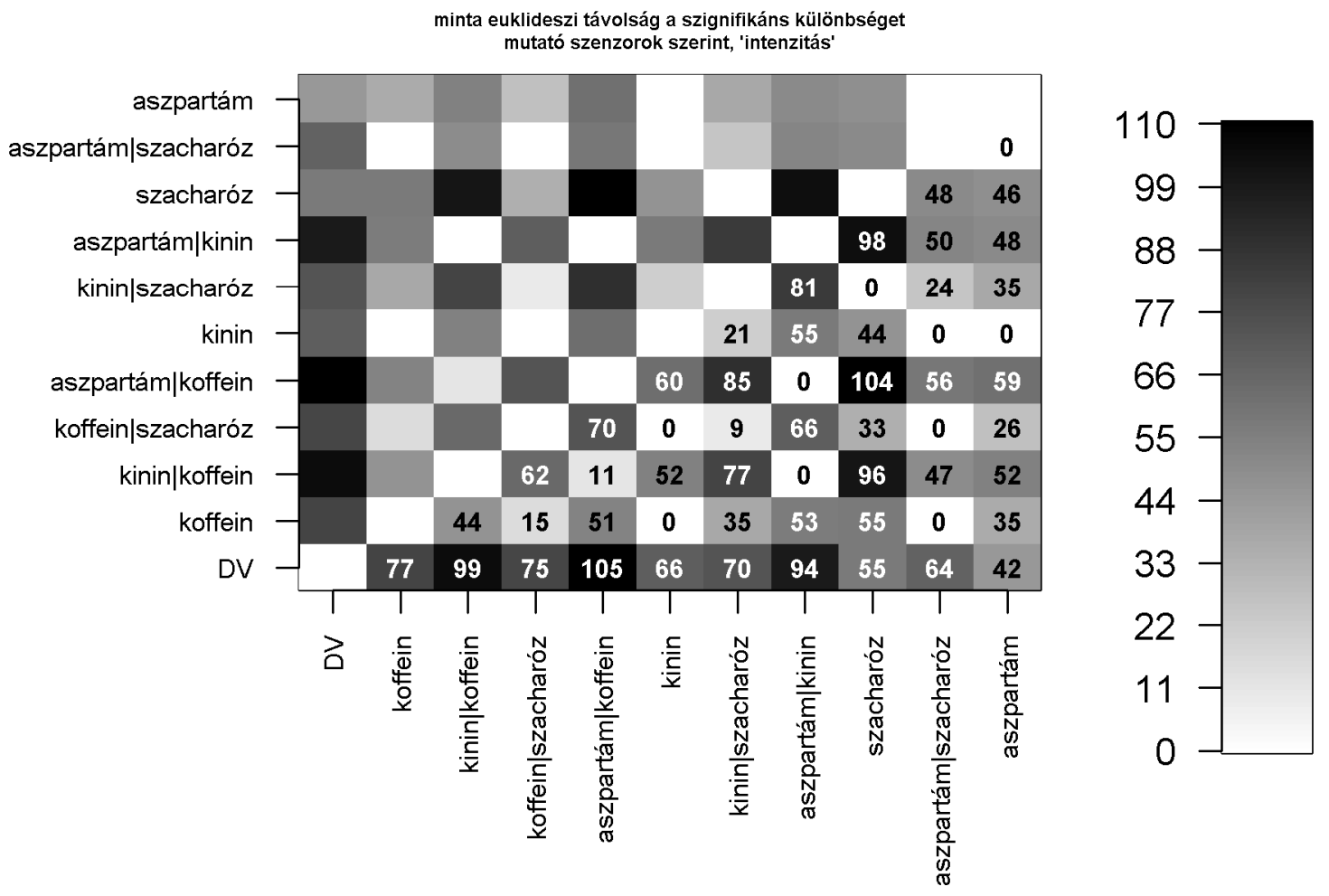

Melléklet 5. ábra Koffein, szacharóz, kinin és aszpartám minták tiszta és kettős kombinációinak páronkénti t-próbája és átlagos euklideszi távolságuk a szignifikáns különbséget adó szenzorok által kifeszített térben. A fehér mezők a különbség nem szignifikáns voltát jelentik. 

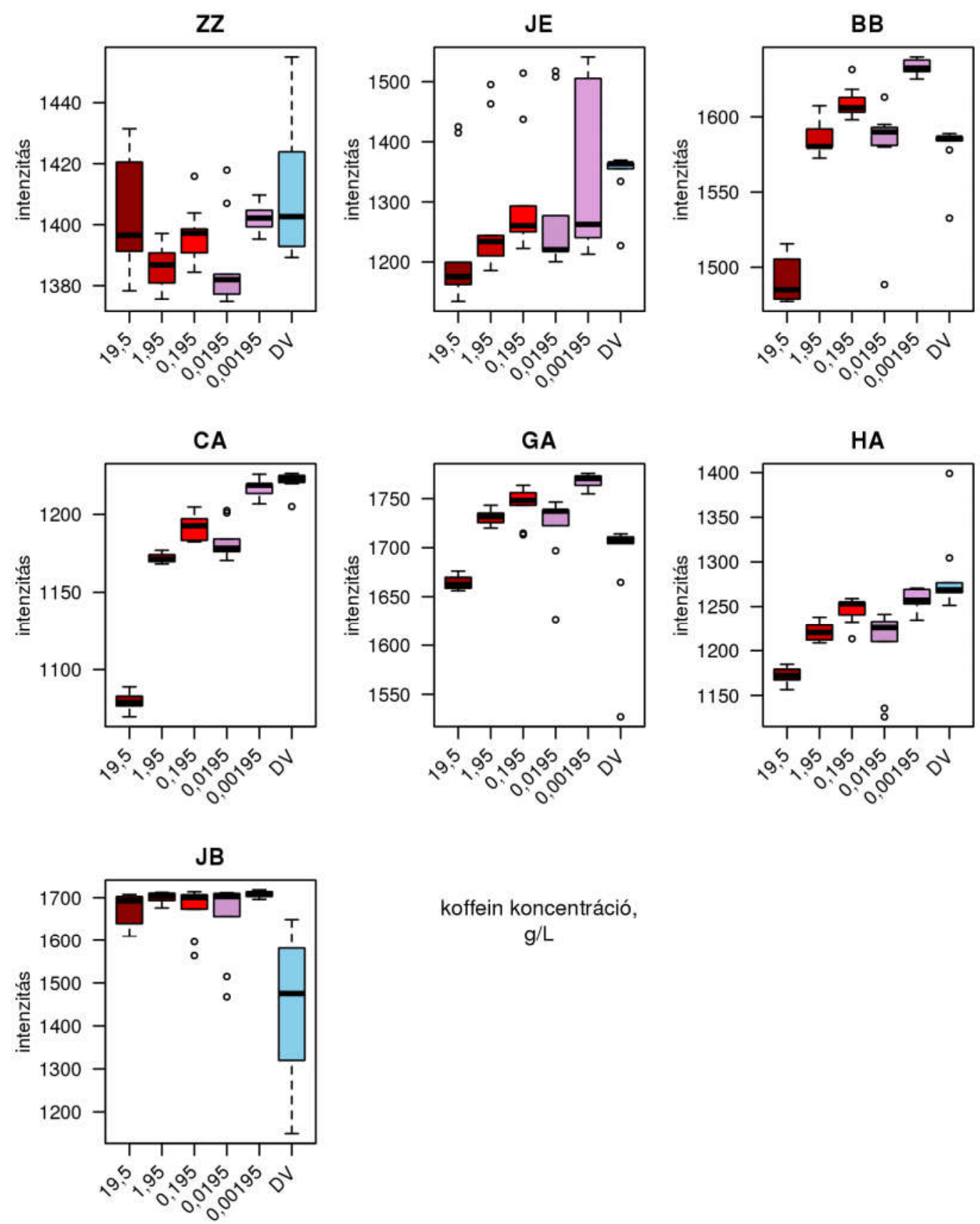

koffein koncentráció, $\mathrm{g} / \mathrm{L}$

Melléklet 6. ábra Különböző koncentrációjú koffein oldatok és a DV elektronikus nyelvvel mért jeleinek boxplot ábrája szenzorokra lebontva. A koffein oldatok könnyebb összehasonlíthatósága miatt a centrum mintát kihagytam az ábrázolásból. 

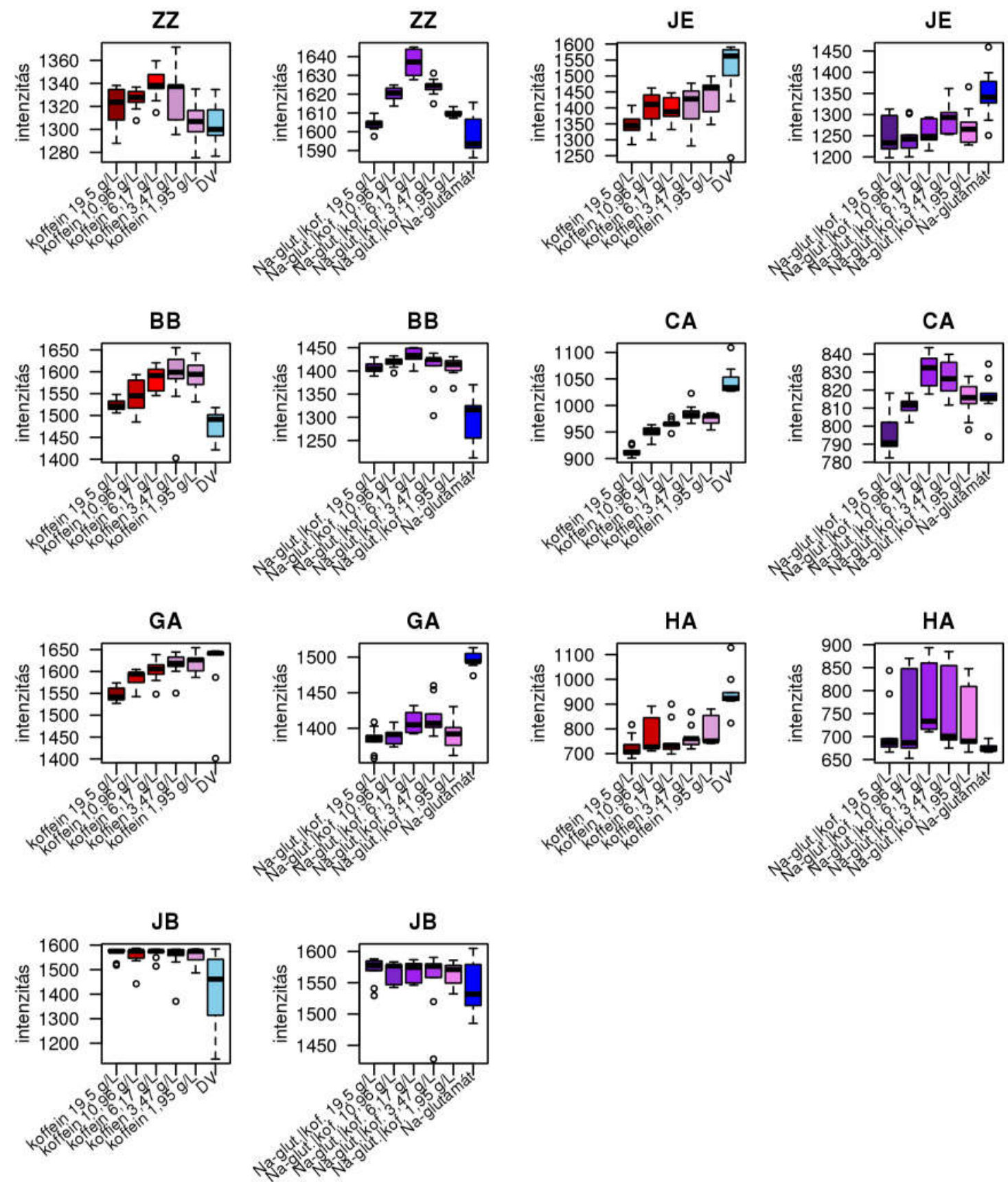

Melléklet 7. ábra Koffein hígítási sor tisztán és 0,29g/L Na-glutamáttal kiegészítve boxplot ábrán. 


\section{Köszönet nyilvánítás}

Szeretném meg köszönni a szakmai segítséget és kitartó támogatást:

- Témavezetőimnek:Dr. Fekete Andrásnak

- Dr. Felföldi Józsefnek

- Dr. Kovács Zoltánnak

Köszönettel tartozom továbbá a dolgozat megszületése során nyújtott közremüködésért:

- Dr. Szöllősi Attilának

- Várvölgyi Evelinnek

- Dr. Sipos Lászlónak

- Soós Jánosnak

- Dr. Vozáry Eszternek

- A Budapesti Corvinus Egyetem Élelmiszertudományi Kar Fizika-Automatika Tanszék munkatársainak

- A Hegelabnak.

Szeretném megköszönni a támogatást és türelmet feleségemnek és az egész családomnak. 